University of Louisville

ThinkIR: The University of Louisville's Institutional Repository

\title{
A comparison of the effectiveness of two suturing techniques for the coronally positioned tunnel procedure with an acellular dermal matrix allograft.
}

Courtney Tyler Shearer

University of Louisville

Follow this and additional works at: https://ir.library.louisville.edu/etd

\section{Recommended Citation}

Shearer, Courtney Tyler, "A comparison of the effectiveness of two suturing techniques for the coronally positioned tunnel procedure with an acellular dermal matrix allograft." (2010). Electronic Theses and Dissertations. Paper 1314.

https://doi.org/10.18297/etd/1314

This Master's Thesis is brought to you for free and open access by ThinkIR: The University of Louisville's Institutional Repository. It has been accepted for inclusion in Electronic Theses and Dissertations by an authorized administrator of ThinkIR: The University of Louisville's Institutional Repository. This title appears here courtesy of the author, who has retained all other copyrights. For more information, please contact thinkir@louisville.edu. 


\title{
A COMPARISON OF THE EFFECTIVENESS OF TWO SUTURING
}

\section{TECHNIQUES FOR THE CORONALLY POSITIONED TUNNEL PROCEDURE}

WITH AN ACELLULAR DERMAL MATRIX ALLOGRAFT

\author{
By \\ Courtney Tyler Shearer \\ D.M.D, University of Louisville Dental School, 2007
}

\begin{abstract}
A Thesis
Submitted to the Faculty of the

In Partial Fulfillment of the Requirements

For the Degree of

Master of Science

Program in Oral Biology

School of Dentistry

University of Louisville

Louisville, Kentucky
\end{abstract}

Graduate School of the University of Louisville

August 2010 


\title{
A COMPARISON OF THE EFFECTIVENESS OF TWO SUTURING
}

TECHNIQUES FOR THE CORONALLY POSITIONED TUNNEL PROCEDURE WITH AN ACELLULAR DERMAL MATRIX ALLOGRAFT.

\author{
By \\ Courtney Tyler Shearer \\ D.M.D., University of Louisville Dental School, 2007
}

A Thesis Approved on

June 23, 2010

By the Following Reading Committee

Thesis Director 


\section{DEDICATION}

This manuscript is dedicated to my husband and two children who have given me unwavering support throughout my career and continue to inspire me daily. 


\section{ACKNOWLEDGEMENTS}

I would like to express my sincere gratitude to the following individuals:

Dr. Henry Greenwell, Program Director of Graduate Periodontics, for his invaluable guidance and mentoring in my training as a periodontist, for his endless effort in advancing the Art and Science of Periodontology, and for his help in the preparation of this thesis.

Dr. Margaret Hill, Assistant Program Director, for her inspiration, continuous encouragement and guidance of all the residents. 


\begin{abstract}
A COMPARISON OF THE EFFECTIVENESS OF TWO SUTURING

TECHNIQUES FOR THE CORONALLY POSITIONED TUNNEL PROCEDURE

WITH AN ACELLULAR DERMAL MATRIX ALLOGRAFT.

Courtney Tyler Shearer, DMD
\end{abstract}

June 23, 2010

\begin{abstract}
Aims. The primary aim of this randomized, blinded, controlled clinical trial was to compare the percent root coverage obtained using a coronally positioned tunnel surgery plus an acellular dermal matrix allograft (ADM) with single tooth sling versus continuous sling sutures 6 months post-surgically.

Methods. Twenty-four patients with 1 site of $\geq 3 \mathrm{~mm}$ Miller Class I or II recession were treated and followed for 6 months. Twelve patients received a coronally positioned tunnel plus ADM and single tooth sling sutures (Single) and were considered the test group. The positive control group consisted of 12 patients treated with a coronally positioned tunnel technique plus ADM with continuous sling sutures (Continuous). Patients were randomly selected by a coin toss to receive either the test or control treatment.
\end{abstract}


Results. The mean facial recession defect at the initial exam for the Single group was $3.4 \pm 0.6 \mathrm{~mm}$ which was reduced to $0.8 \pm 0.8 \mathrm{~mm}$ at the 6 month exam for a gain of $2.5 \pm 0.7 \mathrm{~mm}$ or $76 \%$ defect coverage $(\mathrm{p}<0.05)$. The mean facial recession defect at the initial exam for the Continuous group was $3.0 \pm 0.0 \mathrm{~mm}$ which was reduced to $0.5 \pm 0.8$ $\mathrm{mm}$ at the 6 month exam for a gain of $2.5 \pm 0.8 \mathrm{~mm}$ or $83 \%$ defect coverage $(\mathrm{p}<0.05)$. There were no statistically significant differences between groups $(p>0.05)$. Probing depth increased $0.1 \mathrm{~mm}$ for the Single group and $0.2 \mathrm{~mm}$ for the Continuous group $(\mathrm{p}<$ 0.05 ) from baseline to 6 months. Clinical attachment level increased $2.4 \mathrm{~mm}$ for the Single group $(\mathrm{p}<0.05)$ and $2.3 \mathrm{~mm}$ for the Continuous group $(\mathrm{p}<0.05)$ at the 6 -month final measurement. Mean keratinized tissue increased in the Single group by $0.3 \mathrm{~mm}$ and $0.0 \mathrm{~mm}$ in the Control group $(\mathrm{p}>0.05)$. There were no statistically significant differences between groups $(p>0.05)$. There was no gain of creeping attachment for either the Single or Continuous group.

Conclusions. The coronally positioned tunnel plus ADM and single tooth sling produced $76 \%$ defect coverage while the coronally positioned tunnel plus ADM and continuous sling produced $83 \%$ defect coverage. This difference was considered clinically significant but was not statistically significant. 
TABLE OF CONTENTS

PAGE

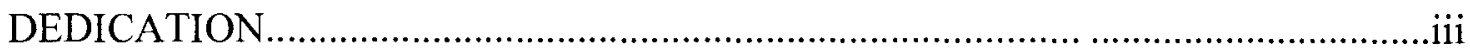

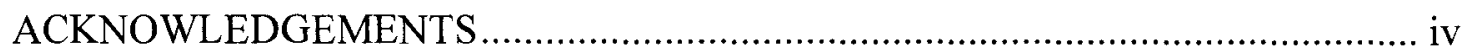

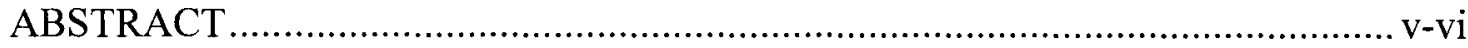

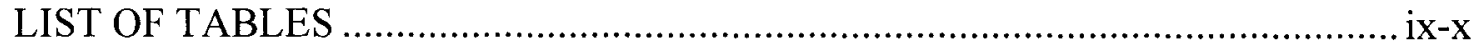

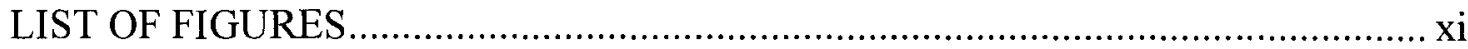

CHAPTER

I. LITERATURE REVIEW

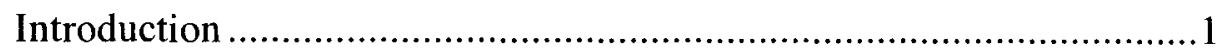

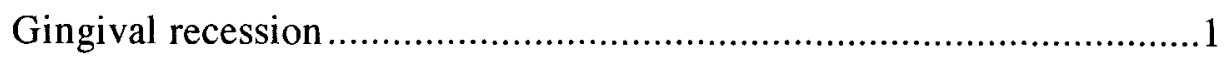

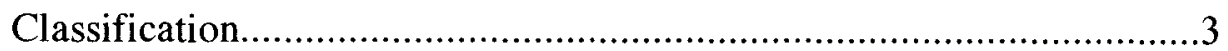

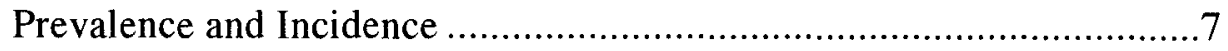

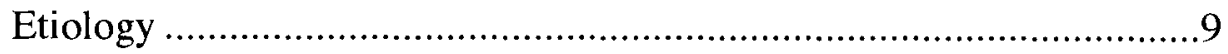

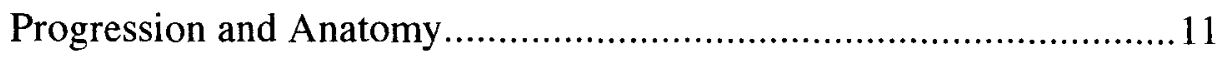

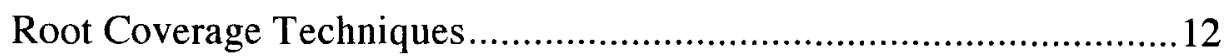

Clinical Studies with Connective Tissue Graft...................................15

Clinical Studies with Coronally Positioned Flap .................................21

Clinical Studies with Acellular Dermal Matrix Allograft .....................25

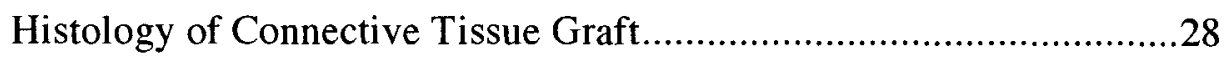

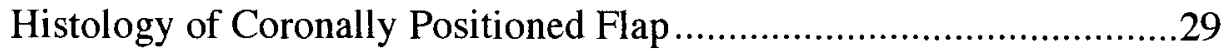

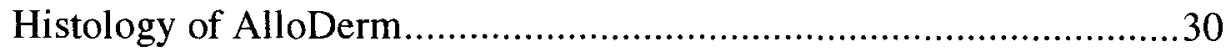

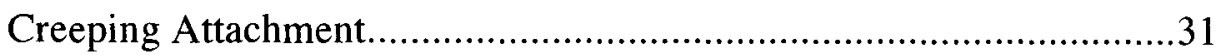

The significance of tissue thickness in root coverage procedures ..........32

II. MATERIALS AND METHODS

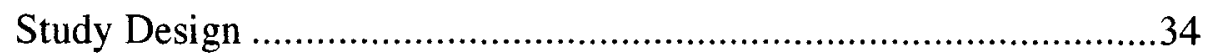

Patient Selection: Inclusion and Exclusion Criteria ...........................35 


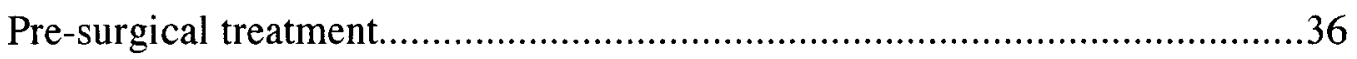

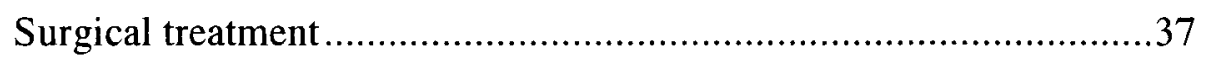

Post-surgical management................................................... 38

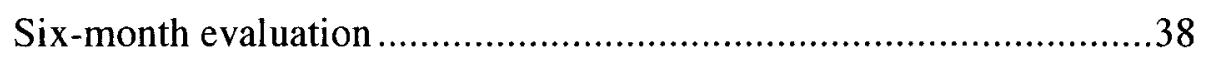

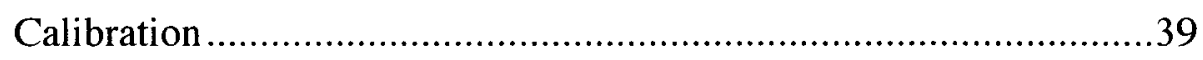

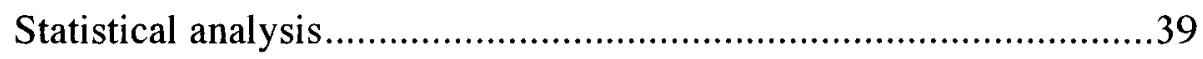

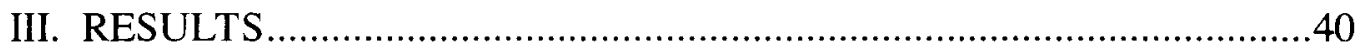

IV. DISCUSSION

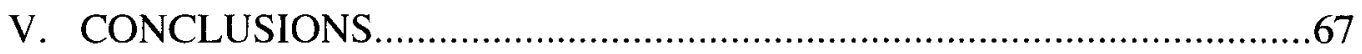

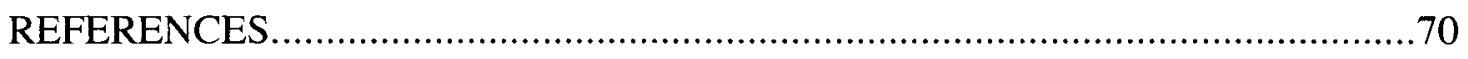

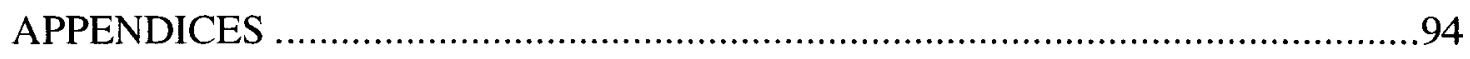

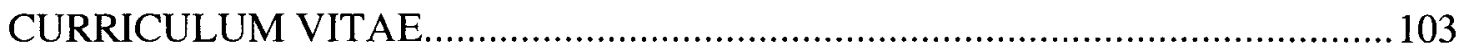




\section{LIST OF TABLES}

TABLE

PAGE

1. Miller's Classification of recession …............................................... 5

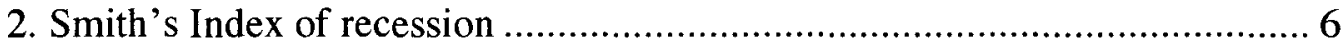

3. Percent prevalence of persons with recession by age group ..................... 8

4. Percent prevalence of teeth with recession by age group......................... 8

5. Connective tissue grafts ......................................................... 19-21

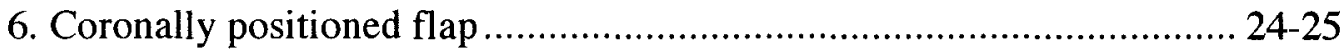

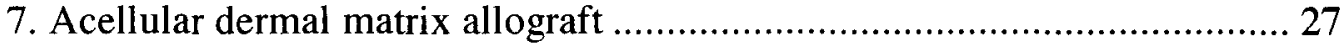

8. Clinical Indices for Test and Control Sites ........................................ 43

9. Probing Measurements for Test and Control Sites ............................... 44

10. Creeping Attachment Mid-buccal.................................................. 45

11. Recession depth vs. dehiscence depth.............................................. 46

12. Recession, defect coverage, root coverage for the Single group.............. 47

13. Recession, defect coverage, root coverage for the Continuous group ........ 48

14. Results of Maxillary Arch Data by Treatment Group....................49

15. Results of Mandibular Arch Data by Treatment Group...................50

16. Results of Maxillary Arch Data Pooled from $3 \mathrm{U}$ of L Studies.............51

17. Results of Mandibular Arch Data Pooled from 3 U of L Studies..........52

18. Results of Maxillary Arch Data Pooled, Stratified.........................53 
19. Results of Mandibular Data Pooled, Stratified............................54

20. Results of Maxillary Data Pooled from 4 U of L Studies...................55

21. Results of Mandibular Data Pooled from 4 U of L Studies.................56

22. Keratinized tissue gain after Alloderm root coverage procedures..............57

23. Creeping attachment after AlloDerm root coverage ................................. 58

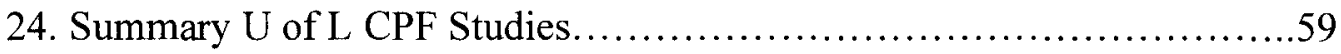

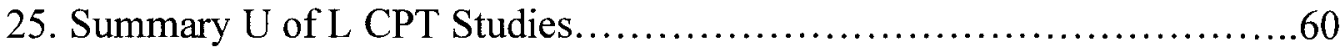

26. Summary Tunnel Maxillary vs. Mandibular Studies......................61

27. Summary Tunnel Maxillary vs. Mandibular Studies Pooled...............62 


\section{LIST OF FIGURES}

FIGURE

PAGE

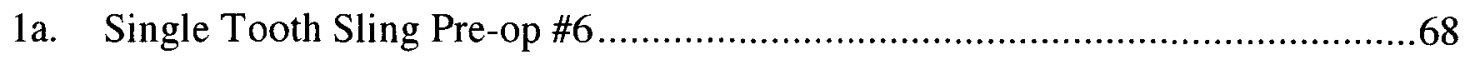

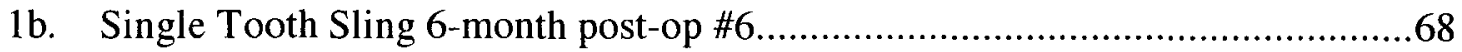

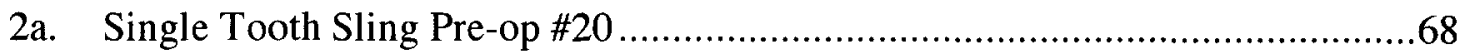

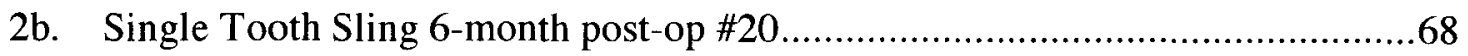

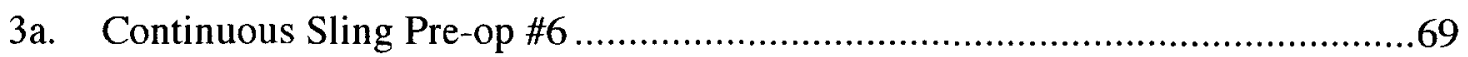

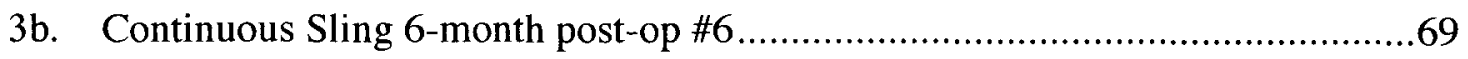

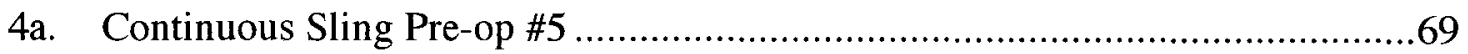

4b. Continuous Sling 6-month post-op \#5 .......................................................69 


\section{CHAPTER I}

\section{LITERATURE REVIEW}

\section{INTRODUCTION}

In the world of periodontics, root coverage procedures, materials, and surgical results have advanced tremendously. These advances have produced an abundance of studies in the process. A denuded root has compromised esthetics and is more susceptible to caries and tooth hypersensitivity. Early root coverage procedures utilized a patient's own tissue and were thus limited in the extent of teeth involved per surgery. New techniques have improved root coverage surgery and allow for better healing, esthetics and defect coverage. Patients now have the option of undergoing single versus multiple surgeries to cover and repair numerous recession defects.

Some patients are more susceptible to gingival recession than others. The need for improved and predictable root coverage procedures is great. Recession is common, and esthetics are in high demand. Thus, root coverage technology and techniques continue to improve.

\section{GINGIVAL RECESSION}

The American Academy of Periodontology defined gingival recession as the location of the gingival margin apical to the cementoenamel junction (Glossary of 
Periodontal Terms, 2001). Armitage (1999) classified gingival recession under the category of Developmental or Acquired Deformities and Conditions, using the subcategory of mucogingival deformities and conditions around teeth. Treatment options for these mucogingival deformities include gingival augmentation and root coverage.

Gingival augmentation is defined as a procedure aimed at increasing the amount of keratinized tissue (American Academy of Periodontology, Glossary of Periodontal Terms, 2001). Gingival augmentation may be required in the presence or absence of gingival recession. Studies examined the use of free gingival grafts as a surgical method for gingival augmentation to increase the amount of keratinized tissue (Bjorn 1963, Nabers 1966).

As the use of free gingival grafts increased, the need to differentiate those sites requiring grafts from those which may remain stable without grafting became apparent. In a 6-week study of various amounts of keratinized tissue and gingival health, Lang and Loe (1972) concluded that $2 \mathrm{~mm}$ of keratinized tissue was necessary in order to maintain gingival health and even with good oral hygiene practice, sites with $<2 \mathrm{~mm}$ of keratinized tissue remained inflamed. However, Miyasato et al. (1977) contradicted that study in an article stating that after 25 days of no oral hygiene, no difference could be seen in the inflammation between sites with minimal keratinized tissue $(<1 \mathrm{~mm})$ and sites with adequate keratinized tissue ( $>2 \mathrm{~mm}$ ). Hangorsky and Bissada (1980) carried out a retrospective study comparing grafted versus non-grafted sites and found that adequate plaque removal alone could maintain good periodontal health and negate the need for grafting in a site with minimal keratinized tissue. In another study comparing grafted versus non-grafted sites, Dorfman $(1980,1982)$ and Kennedy $(1985)$ performed 
prospective longitudinal studies and also found that periodontal health could be maintained with plaque control regardless of the amount of attached gingiva.

In a 5-year study, Wennstrom (1987) examined sites with minimal attached gingiva for recession. He concluded that there is no correlation between the width of attached gingiva and development/progression of gingival recession. In a similar 4-year study of sites with inadequate attached gingiva ( $3 \mathrm{~mm}$ of keratinized tissue, at least $1 \mathrm{~mm}$ of attached gingiva), Salkin et al. (1987) found that $91 \%$ of the sites did not recede over the timeline of the study. In a 10-year longitudinal study, Freedman et al. (1992) found that areas with an inadequate zone of keratinized tissue $(<2 \mathrm{~mm})$ can remain stable and healthy in the presence of good oral hygiene and in the absence of restorative intrusion into the sulcular environment.

In reviewing these results, it is evident that periodontal health is maintainable without augmentation procedures if the patient can exhibit good plaque control. Thus, attention may be directed towards the other widely seen mucogingival defect, facial gingival recession.

\section{Classification}

Over the years, numerous classification systems have been created by various authors. The more notable include Ariaudo (1966), Sullivan and Atkins (1968), Miller (1985), and Smith (1997). Each classification considers gingival architecture and anatomy, recession severity and response to treatment. However, they differ in particular details of recession. 
Before reviewing the various recession classifications, it is important to properly define recession as a whole. The American Academy of Periodontology defined gingival recession as the location of the gingival margin apical to the cementoenamel junction (Glossary of Periodontal Terms, 2001). Ariaudo (1966) strongly considered probe depth and periodontal health into his classification system. Class I: an exposed root surface without periodontal pockets; $100 \%$ root coverage is expected. Class II: an exposed root surface with slight pocketing on adjacent teeth; $100 \%$ root coverage cannot be expected and some loss of gingival coverage of adjacent teeth will result. Class III: an exposed root surface with a deep pocket on the recipient site and/or adjacent teeth; minimal coverage may be achieved. Sullivan and Atkins (1968) classified recession in general terms as shallow or deep, and narrow or wide. Combination terms include shallow narrow, shallow wide, and deep narrow, and deep wide. Predictability and response to treatment decrease as a defect progresses from shallow narrow to deep wide. Miller (1985) considered the relationship between the gingival margin and the mucogingival junction, as well as the interproximal alveolar crest and soft tissue height into his classification (Table 1). His classification system is the most commonly used system to date. 
Table 1

Miller's Classification of Recession

Miller (1985)

\begin{tabular}{|c|c|}
\hline Class & Description \\
\hline I & $\begin{array}{l}\text { Gingival margin does not extend to the mucogingival junction. No bone } \\
\text { or soft tissue loss interproximally; } 100 \% \text { root coverage can be expected. }\end{array}$ \\
\hline II & $\begin{array}{l}\text { Gingival margin extends to or beyond the mucogingival junction. No } \\
\text { bone or soft tissue loss interproximally; } 100 \% \text { root coverage can be } \\
\text { expected. }\end{array}$ \\
\hline III & $\begin{array}{l}\text { Gingival margin extends to or beyond the mucogingival junction. Bone } \\
\text { or soft tissue loss is present interproximally, or there is malpositioning } \\
\text { of the teeth; partial root coverage can be expected. }\end{array}$ \\
\hline IV & $\begin{array}{l}\text { Gingival margin extends to or beyond the mucogingival junction. } \\
\text { Severe bone or soft tissue loss interproximally, and/or malpositioning of } \\
\text { teeth; root coverage cannot be expected. }\end{array}$ \\
\hline
\end{tabular}

Smith (1997) classified recession using a double digit Index of Recession (IR) that considered the horizontal (first number) and vertical (second number), as well as the facial (F) and lingual (L), component. A succeeding asterisk indicated the involvement of the mucogingival junction. (Table 2). 
Table 2

Index of Recession (RI)

Smith (1997)

\begin{tabular}{|c|c|c|}
\hline Component & Class & Description \\
\hline \multirow[t]{6}{*}{ Horizontal } & $\mathbf{0}$ & No clinical evidence of root exposure \\
\hline & 1 & $\begin{array}{l}\text { As } 0 \text {, but subjective awareness of sensitivity to air and / or } \\
\text { exposure of CEJ for up to } 10 \% \text { of the M-D distance }\end{array}$ \\
\hline & 2 & Exposure of the CEJ $>10 \%-\leq 25 \%$ of the M-D distance \\
\hline & 3 & Exposure of the CEJ $>25 \%-\leq 50 \%$ of the M-D distance \\
\hline & 4 & Exposure of the CEJ $>50 \%-\leq 75 \%$ of the M-D distance \\
\hline & 5 & Exposure of the CEJ $>75 \%-\leq 100 \%$ of the M-D distance \\
\hline \multirow[t]{4}{*}{ Vertical } & $\mathbf{0}$ & No clinical evidence of root exposure \\
\hline & 1 & $\begin{array}{l}\text { As } 0 \text {, but subjective awareness of sensitivity to air and / or } \\
\text { exposure of the CEJ not exceeding }>1.0 \mathrm{~mm} \text { vertically to the } \\
\text { gingival margin }\end{array}$ \\
\hline & 2 - 8 & $\begin{array}{l}\text { Root exposure } 2-8 \mathrm{~mm} \text { extending vertically from the CEJ to } \\
\text { the base of soft tissue defect }\end{array}$ \\
\hline & 9 & $\begin{array}{l}\text { Root exposure }>8.0 \mathrm{~mm} \text { from the CEJ to base of soft tissue } \\
\text { defect }\end{array}$ \\
\hline \multirow[t]{2}{*}{ Asterisk } & Present & $\begin{array}{l}\text { Vertical component encroaches into the MGJ or beyond into } \\
\text { alveolar mucosa }\end{array}$ \\
\hline & Absent & Absence or non-involvement of MGJ \\
\hline
\end{tabular}


In a 1980 study of 1003 children approximately 15 years old, Stoner defines pseudorecession and differentiates it from true recession. True recession has been previously defined by the AAP as the gingival margin located apically to the cementoenamel junction. Pseudorecession is defined as the gingival margin located more apically than the gingival margins of adjacent teeth, but properly located coronally to the cementoenamel junction.

\section{Prevalence and Incidence}

In a classic article utilizing data from the NHANES III, 1988-1994, US (Table 3, 4) to present the prevalence of gingival recession in $\geq 30$ year-olds, Albandar (1999) found $23 \%$ had at least $3 \mathrm{~mm}$ recession. Albandar categorized those adults with $\geq 3 \mathrm{~mm}$ recession by age group: $10 \%$ for $30-39$ year-olds, $18 \%$ for $40-49,30 \%$ for $50-59,40 \%$ for $60-69,46 \%$ for $70-79$, and $60 \%$ for $80-90$. This article revealed how each decade of life results in approximately a $10 \%$ increase in the prevalence of gingival recession. Albandar also reported the most common areas of recession include maxillary first molars and mandibular central incisors. Serino (1994) evaluated facial recession in 225 patients and further supported that the most prevalent areas of recession are found in the maxillary molar and mandibular central incisor sites. Serino (1994), as well, categorized subjects by age group and reported on prevalence of recession: $7 \%$ for $18-29$ year-olds, $25 \%$ for 30 $41,33 \%$ for $42-53$, and $40 \%$ for $54-65$. Serino (1994) followed patients for 12 years and found that if the attachment level (AL) was $>2 \mathrm{~mm}$, additional recession was more common. For $3 \mathrm{~mm} \mathrm{AL}, 67 \%$ of sites had additional recession; and $\geq 4 \mathrm{~mm}$ AL had $98 \%$ sites with additional recession. Thus, prevalence of recession increased with age, and 
sites with initial recession were more susceptible to additional recession. A longitudinal study spanning 32 months by O'Leary et al. (1971) examined 470 Air Force cadets for gingival recession and corresponding plaque and gingival scores. Baseline prevalence of gingival recession of $29.4 \%$ increased to $41.3 \%$ at 32 months. Recession sites exhibited higher plaque and gingival indices compared to non-recession sites. Miller et al. (1987) performed a National Survey of Oral Health in the US and found that $50 \%$ of $18-64$ yearolds demonstrated $\geq 1$ site with gingival recession. This number increased to $88 \%$ for individuals 65 or older.

Table 3

Percent Prevalence of Persons with Recession by Age Group

Albandar (1999)

\begin{tabular}{|c|c|c|c|c|}
\hline Age/Recession & $\mathbf{3 0 - 3 9}$ & $\mathbf{4 0 - 4 9}$ & $\mathbf{5 0 - 5 9}$ & Mean \\
\hline$\geq \mathbf{1 ~} \mathbf{~ m m}$ & 38 & 57 & 71 & 58 \\
\hline$\geq \mathbf{3 ~} \mathbf{~ m}$ & 10 & 18 & 30 & 22 \\
\hline$\geq \mathbf{5} \mathbf{~ m m}$ & 2 & 4 & 7 & 6 \\
\hline
\end{tabular}

Table 4

Percent Prevalence of Teeth with Recession by Age Group

Albandar (1999)

\begin{tabular}{|c|c|c|c|c|}
\hline Age/Recession & $\mathbf{3 0 - 3 9}$ & $\mathbf{4 0 - 4 9}$ & $\mathbf{5 0 - 5 9}$ & Mean \\
\hline$<\mathbf{1 ~} \mathbf{~ m m}$ & 36 & 58 & 75 & 56 \\
\hline$\geq \mathbf{1 ~} \mathbf{~ m}$ & 9 & 18 & 32 & 22 \\
\hline $\mathbf{3} \mathbf{3} \mathbf{~ m m}$ & 1 & 2 & 5 & 3 \\
\hline
\end{tabular}


Loe et al. (1992) examined the prevalence of recession over 20 years among Norwegian scholars and Sri Lankan tea workers and emphasized different types of recession among the populations: facial, found mostly with good oral hygiene, and interproximal, found mostly with periodontitis. The Norwegians presented with higher oral hygiene scores and recession was found to be $\geq 60 \%$ facial for age $20,70 \%$ mostly facial for age 30 , and $\geq 90 \%$ mostly facial for 50 year-olds. The Sri Lankans presented with lower oral hygiene scores and recession was found to be $\geq 30 \%$ for those younger than age $20 ; 90 \%$ facial, lingual and interproximally for age $30 ; 100 \%$ for age 40 ; and by age 50, all had recession facial (70\%), lingual (50\%), and interproximally (40\%). In comparing populations of different hygiene levels, it is evident that those with a high level of hygiene develop recession due to mechanical factors (facial/lingual recession) only while maintaining a state of health, whereas the other population developed recession largely due to inflammatory factors present with a state of periodontitis (interproximal recession).

\section{Etiology}

Though there are only two main types of recession, there are numerous theories on the actual cause of gingival recession. As previously differentiated by Loe (1992), there are two main types of recession: facial/lingual recession more commonly found in patients with a healthy interproximal periodontium and no interproximal recession, and interproximal recession, associated with a disease state of periodontitis. Greenwell (2005) recently expanded on these definitions by stating periodontitis related recession is more generalized in extent and is heavily associated with plaque and calculus, whereas 
facial/lingual recession may be more localized. Hirschfeld (1931) focused on these localized, mechanically caused recession defects and stated that they are a result of toothbrush trauma, particularly in anatomical defect areas (presence of dehiscence, tooth malposition) and when using harder toothbrush bristles. Gartrell and Matthews (1976) supported Hirschfeld's article by stating that recession is a result of anatomical osseous defects, such as deshicences. Gorman (1967) ranked, in order of prevalence, etiologic factors causing recession: 1. malalignment, 2. toothbrush trauma, 3. calculus, 4 . inflammation, 5. disuse, 6. occlusal trauma, 7. flat crown curvature, 8. frenum attachment, 9. cervical fillings, 10. crown impingement, and 11. clasp trauma. Stewart (1976) and Pattison (1983) reported on gingival recession as result of self-inflicted (factitial) injuries. Steiner et al. (1981) reported on the effects of labial orthodontic movement in monkeys as an important contributor to gingival recession. Plaque and calculus buildup (Yankell at al. 1990, Joshipura et al. 1994), location and size of restorations (Donaldson 1973, Turner 1982) and frenum attachments (Gottsegen 1954, Ewen 1968) have all been reported as contributing factors to recession.

It has been reported that inflammation contributes to recession (Stillman 1921, Baker and Seymour 1976, Pini Prato 2002). Stillman (1921) described the commonly known "Stillman's cleft" as a cleft forming as a result of occlusal factors. However, the clefts can become inflamed which lead to further recession. Baker and Seymour (1976) described stages in the pathogenesis of gingival recession in rats involving pocket formation followed by necrosis of connective tissue. Pocketing was induced by replacement of natural incisors with dental implants. Conditions were created for recession to occur. In the epithelium and connective tissue deep to the receding margin, 
morphological changes were seen leading to cleft formation and, thus, recession. The cleft histologically appeared to be associated with mononuclear cell infiltration of the connective tissue. Ultimately, the study suggested that a localized inflammatory process caused degeneration of connective tissue by destroying cells, loss of the epithelial layers that were dependent upon the vascularity found within the underlying connective tissue, and gingival recession resulted. Pini Prato (2002) added HSV-1 infection and inflammation to the causes of recession in a case report.

Biotype and genetics are also important contributing factors to gingival recession. Ciancio (1969) evaluated genetics as a contributing factor when he studied twins with recession. He found that environmental factors had more of an impact on recession than genetics or biotype. In contrast, Green and Levin (1973) reported that genetics is a significant factor leading to recession.

Many contributing factors, both acquired (toothbrush trauma, orthodontics, selfinflicted) and inherited (genetics) have been reported. In general, toothbrush trauma is thought to be the primary cause of recession in patients with good oral hygiene. However, there are many other factors to consider (factitial injuries, inflammation, malaligned teeth, restorations, occlusion).

\section{Progression and Anatomy}

Gingival recession occurs when there is either an already underlying dehiscence followed by soft tissue loss, or osseous tissue is destroyed and soft issue recession subsequently occurs. Lost (1984) reported the mean difference between the gingival margin and the depth of the osseous dehiscence is $2.67 \mathrm{~mm}$. He also found that, at the 
time of surgery, a $1 \mathrm{~mm}$ increase in recession depth corresponded to a $1 \mathrm{~mm}$ increase of alveolar bone dehiscence. Thus, osseous and soft tissue may recede synchronously. This begs the question, what is the rate of progression of gingival recession if left untreated?

Serino (1994) followed patients for 12 years and found that if attachment loss (AL) was $>3 \mathrm{~mm}$, additional recession was more common. Thus, recession increased with age, and initial recession of $>2 \mathrm{~mm}$ was more likely to progress.

\section{ROOT COVERAGE}

\section{Techniques}

Root coverage surgical procedures have advanced throughout the years, whether attempting to either cover the exposed root or increase the width of keratinized tissue. Early techniques consisted mostly of pedicle flaps, progressing later to the use of connective tissue autografts both with and without a pedicle flap. The recent advent of allografts have allowed less invasive procedures, eliminating the need for a second surgical site in the patient.

The gold standard of root coverage, as well as soft tissue augmentation, procedures is the connective tissue graft (CTG). It is the most widely used and the most commonly researched technique. Langer and Calagna (1980) studied CTGs for both soft tissue ridge augmentation and root coverage procedures. In a later study, Langer and Calagna (1982) evaluated CTGs for root coverage only. The root coverage technique included vertical releasing incisions and a split thickness flap. Bruno (1994) reported on a similar technique to Langer's utilizing a split-thickness envelope flap for a CTG, however, vertical incisions were not included to promote better healing. Bernimoulin et 


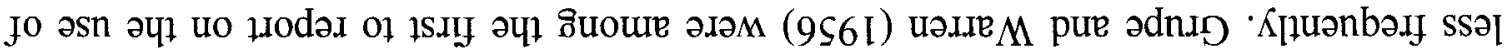

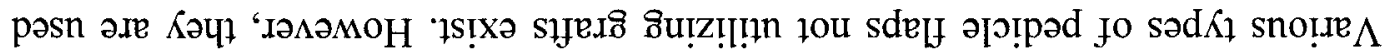

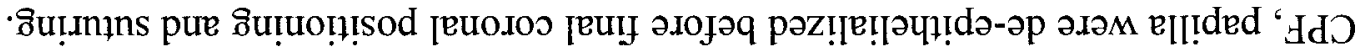

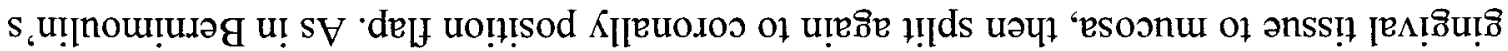

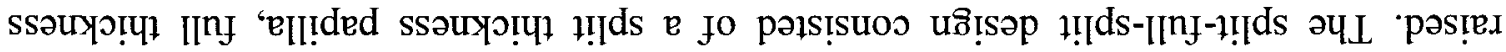

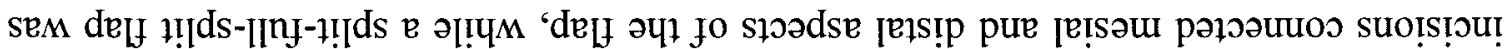

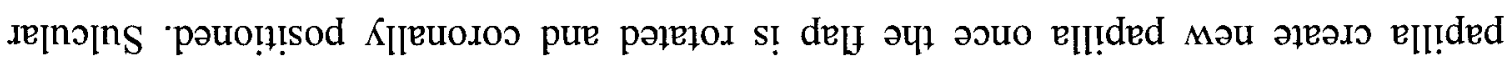

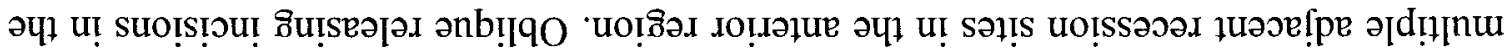

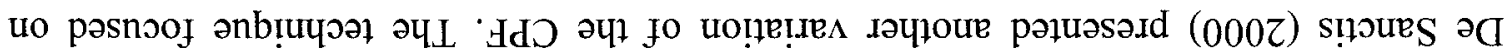

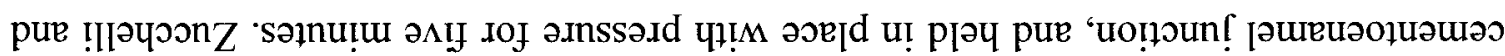

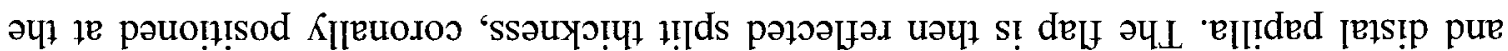

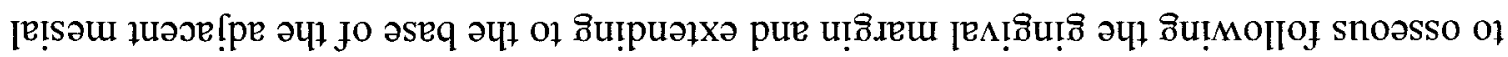

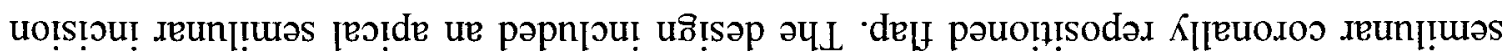

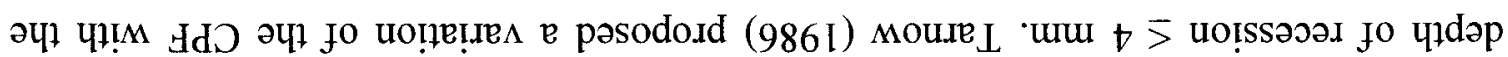

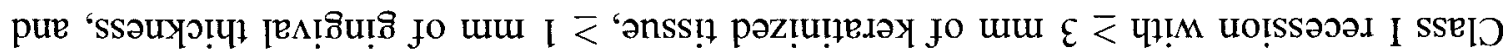

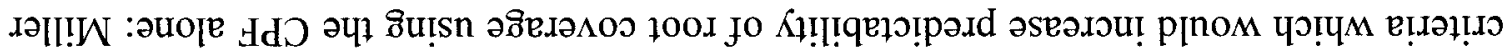

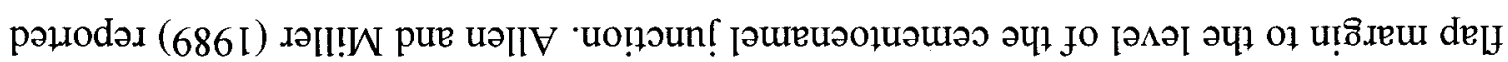

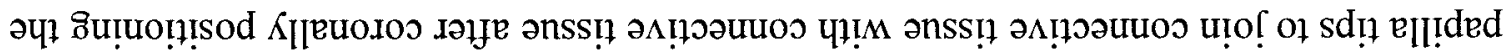

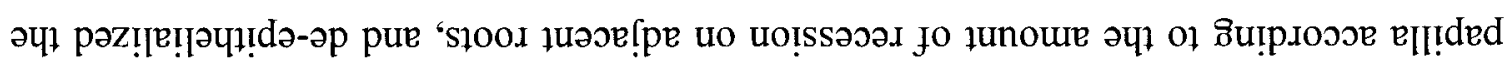

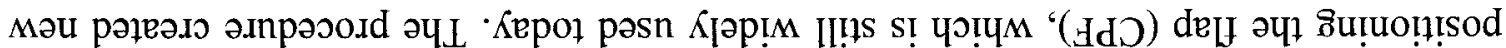

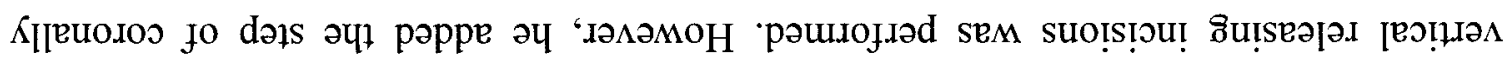

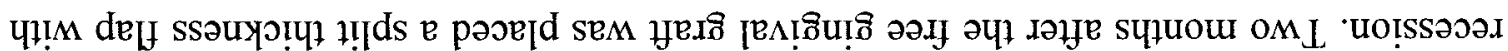

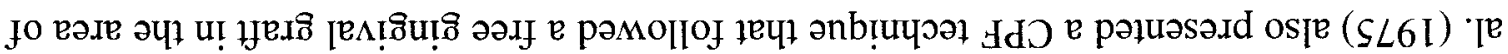


pedicle flaps. They utilized a laterally positioned, or sliding, flap from adjacent teeth to cover the avascular exposed root surface. Smukler and Goldman (1979) observed the need for osseous, and thus a blood supply, over the denuded root and utilized a "laterally positioned stimulated osteoperiosteal pedicle flap" in an effort to stimulate osseous growth, as well as soft tissue coverage. Many others reported on pedicle flaps, including the double papilla repositioned flap (Cohen and Ross 1968), the oblique rotated flap (Pennel et al. 1965), the rotational flap (Patur 1977), the papilla rotation flap (Leis and Leis 1978), and the free rotated papilla autograft (Tinti and Parma-Benfenati 1996).

Numerous other techniques for root coverage have been devised over the years incorporating the CTG, pedicle and envelope flaps. Nelson (1987) presented the technique of a full-thickness flap utilizing a double pedicle and CTG. Full thickness pedicle flaps were made from the papilla adjacent to the recession area and then sutured together overlying a CTG. Harris (1992) altered Nelson's technique by reporting on a technique using split-thickness pedicle flaps on adjacent papilla rather than full-thickness and overlying a CTG. Allen (1994) presented a new technique for the CTG with the introduction of a supraperiosteal envelope without any vertical or horizontal incisions. This tunnel technique was to allow for faster healing with less trauma to the patient. Blanes and Allen (1999) modified Allen's technique by combining the tunnel and double pedicle flap. Raetzke (1985) also had a unique technique of using an envelope with a CTG and creating a split-thickness semilunar "pouch" around the recession site. The CTG could be placed into the pouch with such stability that sutures were often not necessary. This method became known as "Raetzke's pouch". 
The advent of new materials has allowed the classic techniques for root coverage to be implemented with supplementary aid and without having to harvest a CTG from the patient. Thus, only one surgical site is created in attempting root coverage. Dodge (1998) used Alloderm, acellular dermal matrix allograft, with a CPF in his study. Modica (2000) was the first to present a root coverage study using enamel matrix derivative on denuded roots. Cheung and Griffin (2004) combined root coverage surgery with platelet rich plasma (PRP), a blood solution with a dense concentration of platelets and growth factors to promote healing. Wilson (2005) also utilized a solution, fibroblast derived dermal substitute, with his root coverage procedures.

Gingival augmentation procedures, apart from root coverage surgeries, have consistently responded well using a free gingival graft to increase the width of keratinized tissue (Bjorn 1963, Nabers 1966, Sullivan and Atkins 1968). The significance of the free gingival graft thickness for root coverage was not deemed important. Mlinek et al. (1973). Miller $(1982,1983,1985)$ reported that the thicker grafts $(\geq 2.5 \mathrm{~mm})$ resulted in more predictable and greater root coverage than thinner grafts.

\section{Clinical studies with Connective Tissue Graft (CTG)}

Clinical studies utilizing CTG for root coverage are the most widely performed and published studies. Reports show that the CTG technique for root coverage procedures produces the most predictable and long-term stability results of any root coverage technique. These studies include Miller Class I and II defects only due to the issue of bone loss with Miller Class III and IV defects negatively affecting root coverage outcomes. Results of numerous human studies (Table 5) span the length of up to five 
years post-operatively (Harris 2004, Paolantonio et al. 1997). CTG procedures produced a $87 \%$ mean root coverage (range $57 \%-98 \%$ ).

Many studies performed the coronally positioned flap with a CTG. Bouchard et al. (1994) evaluated 15 patients with 15 Miller Class I or II recession defects. CPF plus CTG retaining the epithelial collar surgeries were performed and followed for six months. Half of the sites were treated with citric acid, and half were not treated with citric acid. Mean root coverage obtained was $65 \%$ for no citric acid group and $70 \%$ for citric acid group. In a second study, Bouchard (1997) observed 15 patients with 15 Miller Class I or II defects over six months after utilizing a CPF and CTG technique. Citric acid or tetracycline was applied to each patient. Mean root coverage was $84 \%$ and $79 \%$, respectively. Wennstrom and Zucchelli (1996) performed CPF with CTG on 67 patients with 103 Miller Class I sites and followed them for two years. Mean root coverage of 99\% was obtained. Cordioli et al. (2001) compared CPF to the tunnel technique over one year. In one group, CPF with CTG was performed in 11 patients with 31 Miller Class I or II defects, and in the second group, the envelope technique was performed in 10 patients with 31 sites. Mean root coverage was $95 \%$ and $90 \%$, respectively. Harris (2002) reported on the double pedicle, laterally positioned, and CPF techniques with CTG over 27.5 months in 100 patients with 146 Miller Class I and II recession defects. Mean root coverage obtained was $98.4 \%$. However, mean root coverage was $97.1 \%$ at only 13 weeks, thus, supporting the concept of creeping attachment with CTG. Zucchelli et al. (2003) used a split mouth design in 15 Italian patients with 30 sites of either Miller Class I or II defects to compare a thick CTG and CPF placed at the CEJ to a thin CTG and CPF placed apically to the CEJ. After following patients for 12 months, Zucchelli reported 
mean root coverage of $94.7 \%$ for thick CTGs and $97.3 \%$ for thin CTGs. Burkhardt and Lang (2005) also used a split-mouth design in studying eight patients with Miller Class I and II defects. They compared CPF with CTG using macro- (normal vision, 15 blade, 4-0 suture) versus microsurgical measures ( $5 \mathrm{x}$ loupes magnification, microblades, 7-0 suture). Mean root coverage obtained was $90 \%$ and $98 \%$, respectively. Chambrone et al. (2006) utilized the CPF and CTG in 28 patients with 69 Miller Class I and II defects. The 6-month study compared maxillary defects (14 patients, 34 sites) to mandibular defects (14 patients, 35 sites) and reported mean root coverage of $98 \%$ and $94 \%$, respectively. Erley et al. (2006) performed the CPF and CTG in 17 patients with 22 Miller Class I and II defects. The 6-month study compared the results between smokers ( 8 patients, 11 sites) and non-smokers ( 9 patients, 11 sites) and reported mean root coverage of $82 \%$ and $98 \%$, respectively.

Pedicle flaps have been used overlying CTGs as a means of root coverage. Nelson (1987) studied 14 patients with 29 recession sites utilizing a CTG and double pedicle technique for 6-42 months. He categorized the recession defects as slight $(1-3 \mathrm{~mm})$, moderate $(4-6 \mathrm{~mm})$, and advanced $(7-10 \mathrm{~mm})$. Mean root coverage obtained was $100 \%, 92 \%$, and $88 \%$, respectively. Harris (1992) also used a CTG with double pedicle flap technique. The split-thickness pedicle flap was applied to 20 patients with 30 Miller Class I and II defects and followed for three months. Mean root coverage obtained was 97\%. In another study utilizing a split-thickness double pedicle flap, Harris (1994) used CTG for root coverage on 74 patients with 100 Miller Class I or II recession sites and followed them for six months post-operatively. Mean root coverage obtained was $98 \%$. Tinti and Parma-Benfenati (1996) used the free rotated papilla technique plus a coronally 
positioned split-thickness flap for root coverage on 14 patients with 29 recession sites. Final measurements were taken after 12 months to reveal mean root coverage of $92 \%$. Paolantonio et al. (1997) compared free gingival grafts to subpedicle CTGs in 35 patients with 35 defects over five years and found a mean root coverage for the CTG group to be $85 \%$.

Other techniques utilizing the CTG include envelope and tunnel technique. Raetzke (1985) used his "pouch" technique on 10 patients with 12 sites over eight months and reported mean root coverage of $80 \%$. Allen (1994) used his supraperiosteal tunnel technique with CTGs on 12 patients with 23 Miller Class I and II defects. Final measurements were taken after 12 months to reveal mean root coverage of $84 \%$. Tozum et al. (2005) compared a CTG and tunnel technique (14 patients, 14 sites) to a CTG and Langer and Langer flap technique (17 patients, 17 sites) in 31 patients with 31 Miller Class I and II defects. After a six month post-operative follow-up, Tozum reported mean root coverage of $96 \%$ and $76 \%$, respectively.

Advantages of using CTGs include results that are predictable and stable over the long term (Harris 2004, Paolantonio et al. 1997). However, disadvantages include limitations on amount of tissue, and thus, number of sites included per surgery, and morbidity of donor site. 
Table 5

Connective Tissue Grafts

\begin{tabular}{|c|c|c|c|c|c|c|c|c|c|c|}
\hline Author & $\underline{\mathbf{Y r}}$ & Mean & Mean & Diff & $\underline{\underline{\text { Rpt }}}$ & $\frac{\text { Calc }}{\underline{\%}}$ & \#Pts & 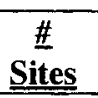 & Time & Miller \\
\hline & & $\underline{\text { Init }}$ & $\underline{\text { Fin }}$ & & Def & Def & & & $\underline{\text { Mo }}$ & Class \\
\hline \multicolumn{11}{|l|}{$\begin{array}{l}\text { Connective } \\
\text { Tissue }\end{array}$} \\
\hline Raetzke & 1985 & 3.29 & 0.67 & 2.62 & 80 & 80 & 10 & 12 & 8 & NR \\
\hline Levine & 1991 & 3.86 & 0.14 & 3.72 & 97 & 96 & 11 & 21 & 3 & NR \\
\hline Harris & 1992 & 3.58 & 0.10 & 3.48 & 97 & 97 & 20 & 30 & 3 & I \& II \\
\hline Jahnke et al. & 1993 & 2.80 & 0.60 & 2.20 & 80 & 79 & 9 & 9 & 6 & I \& II \\
\hline Allen A & 1994 & 3.43 & 0.74 & 2.69 & 84 & 78 & 12 & 23 & 6 & I \& II \\
\hline Borghetti, Louise & 1994 & 3.66 & 1.09 & 2.57 & 71 & 70 & 15 & 15 & 12 & I \& II \\
\hline Bouchard et al. & 1994 & 4.53 & 1.60 & 2.93 & 65 & 65 & 15 & 15 & 6 & I \& II \\
\hline Bouchard et al. & 1994 & 4.20 & 1.27 & 2.93 & 70 & 70 & 15 & 15 & 6 & I \& II \\
\hline Harris & 1994 & 3.30 & 0.10 & 3.20 & 98 & 97 & 74 & 100 & 6 & I \& II \\
\hline Aranda & 1996 & 3.60 & 0.80 & 2.80 & 79 & 78 & 10 & 10 & 6 & NR \\
\hline Ricci et al. & 1996 & 4.88 & 1.05 & 3.83 & 77 & 78 & 18 & 18 & 12 & I \& II \\
\hline Tinti et al. & 1996 & 3.32 & 0.27 & 3.05 & 92 & 92 & 14 & 29 & 12 & I \& II \\
\hline Wennstrom et al. & 1996 & 4.00 & 0.10 & 3.90 & 99 & 98 & 67 & 58 & 24 & I \\
\hline Bouchard et al. & 1997 & 4.13 & 0.66 & 3.47 & 84 & 84 & 15 & 15 & 6 & I \& II \\
\hline Bouchard et al. & 1997 & 3.86 & 0.80 & 3.06 & 79 & 79 & 15 & 15 & 6 & I \& II \\
\hline Harris & 1997 & 3.70 & 0.10 & 3.60 & 97 & 97 & 10 & 10 & 6 & I \& II \\
\hline Paolantonio et al. & 1997 & 3.43 & 0.58 & 2.85 & 85 & 83 & 35 & 35 & 60 & I \& II \\
\hline Harris & 1998 & 3.60 & 0.20 & 3.40 & 95 & 94 & 12 & 19 & 6 & I \& II \\
\hline Jepsen et al. & 1998 & 3.60 & 0.50 & 3.10 & 87 & 86 & 15 & 15 & 12 & I \& II \\
\hline Muller et al. & 1998 & 3.05 & 1.01 & 2.04 & 74 & 67 & 18 & 28 & 12 & I \& II \\
\hline Trombelli et al. & 1998 & 3.00 & 0.50 & 2.50 & 81 & 83 & 12 & 12 & 6 & I \& II \\
\hline Zucchelli et al. & 1998 & 5.60 & 0.30 & 5.30 & 94 & 95 & 18 & 18 & 12 & I \& II \\
\hline Borghetti et al. & 1999 & 3.85 & 0.96 & 2.89 & 76 & 75 & 14 & 14 & 6 & $\mathrm{I}$ \\
\hline Muller et al. & 1999 & 2.48 & 0.60 & 1.88 & 80 & 76 & 13 & 14 & 6 & I \& II \\
\hline Zabalegui et al. & 1999 & 3.38 & 0.33 & 3.05 & 92 & 90 & 4 & 21 & 12 & I \& II \\
\hline Caffesse et al. & 2000 & 2.95 & 0.16 & 2.79 & 95 & 95 & 19 & 19 & 6 & I \& II \\
\hline Caffesse et al. & 2000 & 3.00 & 0.44 & 2.56 & 85 & 85 & 17 & 17 & 6 & I \& II \\
\hline Harris & 2000 & 3.40 & 0.20 & 3.20 & 96 & 94 & 25 & 42 & 3 & I \& II \\
\hline Rosetti et al. & 2000 & 4.16 & 0.20 & 3.96 & 96 & 95 & 12 & 12 & 18 & I \& II \\
\hline Tatakis, Trombelli & 2000 & 2.50 & 0.10 & 2.40 & 96 & 96 & 12 & 12 & 6 & I \& II \\
\hline $\begin{array}{l}\text { Aichelmann- } \\
\text { Reidy et al. }\end{array}$ & 2001 & 3.00 & 0.80 & 2.20 & 74 & 73 & 22 & 22 & 6 & I \& II \\
\hline Cordioli et al. & 2001 & 3.50 & 0.20 & 3.30 & 95 & 94 & 11 & 31 & 12 & I \& II \\
\hline Cordioli et al. & 2001 & 3.60 & 0.50 & 3.10 & 90 & 86 & 10 & 31 & 12 & I \& II \\
\hline Muller et al. & 2001 & 2.49 & 0.57 & 1.92 & 82 & 77 & 13 & 14 & 12 & I \& II \\
\hline Novaes et al. & 2001 & 2.97 & 1.13 & 1.84 & 65 & 62 & 9 & 9 & 6 & I \& II \\
\hline Romagna-Genon & 2001 & 3.76 & 0.57 & 3.19 & 85 & 85 & 20 & 20 & 6 & I \& II \\
\hline Wang et al. & 2001 & 3.40 & 0.70 & 2.70 & 84 & 79 & 16 & 16 & 6 & I \& II \\
\hline Harris & 2002 & 3.70 & 0.10 & 3.60 & 98 & 97 & 100 & 122 & 3 & I \& II \\
\hline Harris & 2002 & 3.50 & 0.20 & 3.30 & 96 & 94 & 100 & 144 & 3 & I \& II \\
\hline Paolantonio & 2002 & 4.60 & 0.46 & 4.14 & 90 & 90 & 15 & 15 & 12 & I \& II \\
\hline
\end{tabular}




\begin{tabular}{|c|c|c|c|c|c|c|c|c|c|c|}
\hline Paolantonio et al. & 2002 & 4.80 & 0.53 & 4.27 & 89 & 89 & 15 & 15 & 12 & I\& II \\
\hline Harris & 2002 & 3.82 & 0.08 & 3.74 & 98 & 98 & 100 & 146 & 28 & I \& II \\
\hline Tal et al. & 2002 & 4.86 & 0.57 & 4.29 & 89 & 88 & 7 & 7 & 12 & I \& II \\
\hline Lee et al. & 2002 & 3.67 & 0.33 & 3.34 & 91 & 91 & 15 & 21 & 36 & I-III \\
\hline Goldstein et al. & 2002 & 4.09 & 0.12 & 3.97 & 97 & 97 & 33 & 33 & 34 & I \& II \\
\hline Goldstein et al. & 2002 & 3.44 & 0.31 & 3.13 & 92 & 91 & 27 & 27 & 32 & I \& II \\
\hline Harris & 2003 & 4.40 & 0.50 & 3.90 & 91 & 89 & 50 & 50 & 3 & I\& II \\
\hline McGuire, Nunn & 2003 & 4.25 & 0.2 & 4.01 & 94 & 94 & 17 & 17 & 12 & I \& II \\
\hline Zucchelli et al. & 2003 & 4.00 & 0.10 & 3.90 & 97 & 98 & 15 & 15 & 12 & I \& II \\
\hline Zucchelli et al. & 2003 & 3.90 & 0.30 & 3.60 & 95 & 92 & 15 & 15 & 12 & I \& II \\
\hline Cetiner et al. & 2003 & 3.80 & 0.60 & 3.20 & 86 & 84 & 30 & 20 & 12 & I \& II \\
\hline Al-Zahrani et al. & 2004 & 3.78 & 1.34 & 2.44 & 65 & 65 & 13 & 16 & 3 & I \& II \\
\hline Al-Zahrani et al. & 2004 & 3.94 & 1.69 & 2.25 & 57 & 57 & 13 & 16 & 3 & I \& II \\
\hline da Silva et al. & 2004 & 4.20 & 1.04 & 3.16 & 75 & 75 & 11 & 11 & 6 & $I$ \\
\hline Martins et al. & 2004 & 3.73 & 1.55 & 2.18 & 59 & 58 & 7 & 9 & 4 & I \& II \\
\hline Martins et al. & 2004 & 3.66 & 0.94 & 2.72 & 75 & 74 & 7 & 9 & 4 & I \& II \\
\hline Nemcovsky et al. & 2004 & 4.60 & 0.60 & 4.00 & 87 & 87 & 40 & 40 & 12 & I\& II \\
\hline Harris & 2004 & 3.80 & 0.10 & 3.70 & 97 & 97 & 25 & 39 & 49 & I \& II \\
\hline Francetti et al. & 2004 & 3.38 & 0.13 & 3.25 & 97 & 96 & 16 & 16 & 12 & I \& II \\
\hline Cetiner et al. & 2004 & 3.11 & 0.11 & 3.00 & 96 & 96 & 10 & 52 & 12 & I \& II \\
\hline Vergara, Caffesse & 2004 & 2.65 & 0.23 & 2.42 & 91 & 91 & 50 & 41 & 6 & $\mathrm{I}$ \\
\hline Vergara, Caffesse & 2004 & 3.48 & 0.49 & 2.99 & 86 & 86 & 50 & 60 & 6 & II \\
\hline Cheung \& Griffin & 2004 & 2.48 & 0.17 & 2.31 & 95 & 93 & 15 & 29 & 8 & I\& II \\
\hline Wilson et al. & 2005 & 3.90 & 1.40 & 2.50 & 64 & 64 & 13 & 13 & 6 & I \& II \\
\hline Burkhardt \& Lang & 2005 & 4.14 & 0.09 & 4.05 & 98 & 98 & 8 & 8 & 12 & I\& II \\
\hline Burkhardt \& Lang & 2005 & 4.19 & 0.44 & 3.75 & 90 & 89 & 8 & 8 & 12 & I\& II \\
\hline Harris et al. & 2005 & 2.90 & 0.60 & 2.30 & 80 & 79 & 21 & 41 & 3 & I\& II \\
\hline Harris et al. & 2005 & 3.20 & 0.20 & 3.00 & 96 & 94 & 21 & 39 & 3 & I \& II \\
\hline Harris et al. & 2005 & 2.90 & 0.30 & 2.60 & 91 & 90 & 21 & 38 & 3 & I \& II \\
\hline Tozum et al. & 2005 & 3.50 & 0.14 & 3.36 & 96 & 96 & 14 & 14 & 6 & I \& II \\
\hline Tozum et al. & 2005 & 3.47 & 0.97 & 2.50 & 76 & 72 & 17 & 17 & 6 & I \& II \\
\hline Hirsch et al. & 2005 & 4.90 & 0.10 & 4.80 & 98 & 98 & 65 & 169 & 24 & I \& II \\
\hline Bittencourt et al. & 2006 & 2.15 & 0.10 & 2.05 & 96 & 95 & 17 & 17 & 6 & $\mathrm{I}$ \\
\hline Moses et al. & 2006 & 4.57 & 0.70 & 3.87 & 84 & 85 & 37 & 37 & 24 & I\& II \\
\hline Chambrone et al. & 2006 & 3.89 & 0.07 & 3.82 & 98 & 98 & 14 & 34 & 6 & I \& II \\
\hline Chambrone et al. & 2006 & 3.64 & 0.21 & 3.43 & 94 & 94 & 14 & 35 & 6 & I \& II \\
\hline Erley et al. & 2006 & 3.33 & 1.00 & 2.33 & 82 & 70 & 8 & 11 & 6 & I\& II \\
\hline Erley et al. & 2006 & 3.20 & 0.20 & 3.00 & 98 & 94 & 9 & 11 & 6 & I \& II \\
\hline Carvalho et al. & 2006 & 2.10 & 0.07 & 2.03 & 97 & 97 & 10 & 29 & 6 & I \& II \\
\hline Kassab et al. & 2006 & 4.00 & 0.10 & 3.90 & 98 & 98 & 10 & 10 & 6 & I \& II \\
\hline Kassab et al. & 2006 & 4.30 & 0.10 & 4.20 & 98 & 98 & 10 & 10 & 6 & I \& II \\
\hline Rahmani et al. & 2006 & 3.70 & 1.10 & 2.60 & 70 & 70 & 10 & 10 & 6 & I \& II \\
\hline Joly et al. & 2007 & 4.40 & 0.90 & 3.50 & 80 & 80 & 10 & 10 & 6 & I \& II \\
\hline Jankovic et al. & 2007 & 3.45 & 0.38 & 3.07 & 89 & 89 & 15 & 30.0 & 6.0 & I \& II \\
\hline Harris et. al. & 2007 & 3.90 & 0.20 & 3.70 & 95 & 95 & 60 & 85 & 3.0 & I \& II \\
\hline Harris et. al. & 2007 & 3.70 & 0.10 & 3.60 & 98 & 97 & 60 & 91 & 3.0 & I \& II \\
\hline Dembowska et al. & 2007 & 2.60 & 0.10 & 2.50 & 99 & 96 & 18 & 24 & 12.0 & I \& II \\
\hline Dembowska et al. & 2007 & 3.10 & 0.30 & 2.80 & 99 & 90 & 18 & 18 & 12.0 & I \& II \\
\hline Souza et al. & 2008 & 3.47 & 1.48 & 1.99 & 58 & 57 & 30 & 30 & 6 & I \& II \\
\hline Souza et al. & 2008 & 3.15 & 0.52 & 2.63 & 83 & 83 & 30 & 30 & 6 & I \& II \\
\hline Andia et al. & 2008 & 3.60 & 1.80 & 1.80 & 50 & 50 & 22 & 22 & 24 & I\& II \\
\hline
\end{tabular}




\begin{tabular}{|c|c|c|c|c|c|c|c|c|c|c|}
\hline Andia et al. & 2008 & 3.60 & 0.80 & 2.80 & 78 & 78 & 22 & 22 & 24 & I\& II \\
\hline Gunay et al. & 2008 & 4.4 & 0.4 & 4.00 & 92 & 91 & 20 & 36 & 24 & I \& II \\
\hline de Souza et al. & 2008 & 2.93 & 0.78 & 2.15 & & 73 & 7.0 & 13.0 & 12.0 & I\& II \\
\hline Han et al. & 2008 & 2.5 & 0.3 & 2.20 & 88 & 88 & 10 & 11.0 & 3.0 & I \& II \\
\hline Han et al. & 2008 & 2.7 & 0.2 & 2.50 & 93 & 93 & 10 & 14.0 & 3.0 & I\& II \\
\hline Bittencourt et al. & 2009 & 2.15 & 0.07 & 2.08 & 97 & 97 & 17 & 17.0 & 30.0 & I \\
\hline Byun et al. & 2009 & 2.45 & -0.35 & 2.80 & 98 & 114 & 20 & 10.0 & 6.0 & $I \&$ II \\
\hline Byun et al. & 2009 & 2.53 & 0.1 & 2.43 & 89 & 96 & 20 & 10.0 & 6.0 & I \& II \\
\hline Georges et al. & 2009 & 3.76 & 0.54 & 3.22 & 85 & 86 & 35 & 68.0 & 6.0 & I \& II \\
\hline Haghighati et al. & 2009 & 3.37 & 1.06 & 2.31 & 69 & 69 & 16 & 16.0 & 6.0 & I \& II \\
\hline Cortellini et al. & 2009 & 2.7 & 0.6 & 2.10 & & 78 & 42 & 42.0 & 6.0 & I \& II \\
\hline Abolfazli et al. & 2009 & 4.83 & 0.33 & 4.5 & 93 & 93 & 12 & 12 & 6 & I \\
\hline Count & 103 & & & & & & & & & \\
\hline Mean & & 3.57 & 0.50 & 3.07 & 87 & 86 & 22.08 & 28.77 & 10.38 & \\
\hline sd & & 0.68 & 0.43 & 0.73 & 11.29 & 11.79 & 19.41 & 29.31 & 9.56 & \\
\hline
\end{tabular}

\section{Clinical studies with Coronally Positioned Flap (CPF)}

The coronally positioned flap can be a predictable technique to use in root coverage procedures, particularly if a graft of some sort is used simultaneously. Many authors reported on the use of CPFs in root coverage (Table 6). Mean root coverage was $79 \%$ (range $34 \%-98 \%$ ).

Bernimoulin (1975) was the earliest to report on the CPF technique. Though his first surgery included a free gingival graft to increase the zone of keratinized tissue, the specific CPF technique that followed is widely practiced today. The design included oblique vertical incisions, sulcular horizontal incisions that created new papilla with which the coronally positioned flap would overlay. The tip of the new papilla was created a distance from the tip of the current papilla equal to the amount of recession. The papilla was then de-epithelialized, the flap reflected full-thickness to the mucogingival junction, then split to coronally position the flap at or above the cementoenamel junction.

Numerous studies have been completed in attempts to describe tools to increase predictability of root coverage using the CPF alone. Among these are Allen and Miller 
(1989), Pini Prato (1999, 2000), and Baldi (1999). Allen and Miller (1989) reported anatomical requirements for predictable root coverage using the CPF in a study of 28 patients with 37 Miller Class I recession sites. This included Miller Class I recession with $\geq 3 \mathrm{~mm}$ keratinized tissue, $\geq 1 \mathrm{~mm}$ gingival thickness, and recession defect depth $\leq 4$ $\mathrm{mm}$. Final measurements were taken at six months and revealed a predictable mean root coverage of $98 \%$. Pini Prato et al. (1999) compared CPF with SRP to CPF with root polishing in 10 patients with 10 Miller Class I and II recession defects. Mean root coverage after three months was $83 \%$ for the SRP group and $89 \%$ for the polished group. Baldi et al. (1999) reported the relationship between tissue thickness and root coverage predictability. He studied 19 patients with 19 Miller Class I and II defects receiving a CPF over three months. Patients were classified as having either thin $(<0.8 \mathrm{~mm} ; 11$ patients) or thick ( $\geq 0.8 \mathrm{~mm} ; 11$ patients) tissue. Overall mean root coverage obtained was $82 \%$. Patients with thick tissue had $100 \%$ root coverage, while patients with thin tissue only achieved 37\% mean root coverage. Pini Prato et al. (2000) studied the effect of flap tension on root coverage results. He reported on 11 patients with 22 Miller Class I defects receiving CPF over three months. Patients either received a CPF procedure that applied tension (11 patients) or did not apply tension (11 patients) to the flap. Results showed that tension on a flap of a CPF decreased mean root coverage: $78 \%$ for flaps with tension group, $87 \%$ for flaps without tension.

Wennstrom and Zucchelli (1996) followed 67 patients with 103 defect sites with $\geq 3 \mathrm{~mm}$ recession for 24 months after performing either a coronally advanced flap alone (45 sites) or in combination with a free CTG (58 sites). At six months, the flap alone group mean root coverage obtained was $97 \%$. Mean root coverage for the flap plus CTG 
group was $99 \%$. However, this percentage fell to $80 \%$ and $88 \%$ for flap alone and flap with CTG, respectively. Woodyard et al. (2004) studied 24 patients with 1 Miller Class I or II defect sites each and compared either a CPF alone (12 sites) or in combination with ADM (12 sites). At the end of the six month post-operative period mean root coverage obtained was $67 \%$ for the CPF alone group. Leknes et al. (2005) performed a CPF alone on 20 subjects with 20 Miller Class I or II defects and followed the patients for six years post-operatively. Mean root coverage obtained was $98 \%$. Zucchelli and De Sanctis (2005) also completed a study using a CPF alone group in 22 patients with 73 Miller Class I recession defects. Mean root coverage obtained was $95 \%$ after a five year postoperative period.

Silva et al. (2006) observed the importance of smoking status on the effects of the CPF. His study divided 20 patients receiving with 20 Miller Class I recession sites and receiving a CPF into two groups: current smokers ( $\geq 10$ cigarettes/ day for past 5 years; 10 patients) and non-smokers (never smokers; 10 patients). After a six month follow-up period mean root coverage obtained for smokers was $69 \%$ versus $91 \%$ for non-smokers. Smoking had a negative affect on the CPF root coverage technique.

Mean root coverage for the CPF surgical method for the studies presented here was $79 \%$ (range $34-98 \%$; Table 6). Even with publications that describe methods to increase predictability of root coverage utilizing the CPF (Allen and Miller, Pini Prato) many factors alter these qualifications and require a different surgical approach. These cases call for a type of graft (Alloderm or CTG) to be used in combination with the CPF. 
Table 6

Coronally Positioned Flap

\begin{tabular}{|c|c|c|c|c|c|c|c|c|c|c|}
\hline Author & $\underline{\mathbf{Y r}}$ & Mean & Mean & Diff & $\frac{\mathbf{R p t}}{\%}$ & $\frac{\text { Calc }}{\%}$ & \#Pts & $\begin{array}{c}\# \\
\text { Sites }\end{array}$ & Time & Miller \\
\hline & & $\begin{array}{l}\text { Init } \\
\text { Rec }\end{array}$ & $\frac{\text { Fin }}{\text { Rec }}$ & & Def & $\underline{\overline{\text { Rt }}}$ & & & Mo & Class \\
\hline \multicolumn{11}{|l|}{ CPF } \\
\hline$\overline{\text { Allen, Miller }}$ & 1989 & 3.25 & 0.07 & 3.18 & 98 & 99 & 28 & 37 & 6 & I \\
\hline Romanos et al. & 1993 & 3.76 & 1.12 & 2.64 & 70 & 92 & 18 & 75 & 60 & NR \\
\hline Trombelli et al. & 1996 & 3.80 & 1.40 & 2.40 & 65 & 90 & 11 & 11 & 6 & I \& II \\
\hline Trombelli et al. & 1996 & 3.40 & 1.70 & 1.70 & 55 & 88 & 11 & 11 & 6 & I \& II \\
\hline $\begin{array}{l}\text { Wennstrom, } \\
\text { Zucchelli }\end{array}$ & 1996 & 4.10 & 0.20 & 3.90 & 97 & 99 & 67 & 45 & 24 & I \\
\hline Milano & 1998 & 3.27 & 0.64 & 2.63 & 84 & 95 & 11.0 & 11.0 & 12.0 & I \& II \\
\hline Baldi et al. & 1999 & 3.00 & 0.60 & 2.40 & 82 & 96 & 19 & 19 & 3 & I \& II \\
\hline Pini Prato et al. & 1999 & 2.90 & 0.50 & 2.50 & 83 & 96 & 10 & 10 & 3 & I \& II \\
\hline Pini Prato et al. & 1999 & 3.10 & 0.40 & 2.60 & 89 & 97 & 10 & 10 & 3 & I \& II \\
\hline Amarante et al. & 2000 & 3.60 & 1.10 & 2.50 & 89 & 92 & 20 & 20 & 6 & I \& II \\
\hline Modica et al. & 2000 & 3.5 & 0.79 & 2.71 & 81 & 94 & 12.0 & 14.0 & 6.0 & I \& II \\
\hline Pini Prato et al. & 2000 & 2.82 & 0.64 & 2.18 & 78 & 95 & 11 & 11 & 3 & I \\
\hline Pini Prato et al. & 2000 & 2.68 & 0.36 & 2.32 & 87 & 97 & 11 & 11 & 3 & $I$ \\
\hline Saletta et al. & 2001 & 2.77 & 0.5 & 2.27 & 82 & 96 & 33.0 & 33.0 & 3.0 & I \\
\hline Hagewald et al. & 2002 & 3.9 & 1.0 & 2.90 & 79 & 93 & 36.0 & 36.0 & 12.0 & I \& II \\
\hline Lins et al. & 2003 & 3.3 & 1.3 & 2.00 & 60 & 90 & 10 & 10 & 6 & I \& II \\
\hline Woodyard et al. & 2004 & 3.27 & 1.08 & 2.19 & 67 & 92 & 12 & 12 & 6 & I \& II \\
\hline da Silva et al. & 2004 & 3.98 & 1.25 & 2.73 & 69 & 91 & 11 & 11 & 6 & I \\
\hline Pini Prato et al. & 2005 & 3.18 & 0.32 & 2.86 & 91 & 98 & 60 & 60 & 6 & I \\
\hline Leknes et al. & 2005 & 3.80 & 2.50 & 1.30 & 34 & 82 & 11 & 11 & 72 & I \& II \\
\hline Cortes et al. & 2004 & 3.58 & 1.08 & 2.50 & 71 & 92 & 13 & 13 & 6 & I \\
\hline Huang et al. & 2005 & 2.90 & 0.50 & 2.40 & 82 & 96 & 23 & 23 & 6 & I \\
\hline $\begin{array}{l}\text { Zucchelli \& } \\
\text { DeSanctis }\end{array}$ & 2005 & 2.78 & 0.22 & 2.56 & 95 & 98 & 22 & 73 & 60 & I \& II \\
\hline Huang et al. & 2005 & 2.90 & 0.50 & 2.40 & 84 & 96 & 12 & 12 & 6 & I \\
\hline DelPizzo et al. & 2005 & 4.13 & 0.60 & 3.53 & 87 & 96 & 15 & 15 & 24 & I \& II \\
\hline Spahr et al. & 2005 & 3.80 & 1.40 & 2.40 & 67 & 90 & 30 & 30 & 24 & I \& II \\
\hline Silva et al. & 2006 & 2.74 & 0.84 & 1.90 & 69 & 94 & 10 & 10 & 6 & I \\
\hline Silva et al. & 2006 & 2.54 & 0.22 & 2.32 & 91 & 98 & 10 & 10 & 6 & I \\
\hline $\begin{array}{l}\text { Bittencourt et } \\
\text { al. }\end{array}$ & 2006 & 2.20 & 0.21 & 1.99 & 91 & 98 & 17 & 17 & 6 & I \\
\hline $\begin{array}{l}\text { Castellanos et } \\
\text { al. }\end{array}$ & 2006 & 2.31 & 0.90 & 1.41 & 62 & 93 & 11 & 11 & 12 & I \& II \\
\hline $\begin{array}{l}\text { de Queiroz } \\
\text { Cortes et al. }\end{array}$ & 2006 & 3.58 & 1.62 & 1.96 & 56 & 88 & 13 & 13 & 24 & I \\
\hline Pilloni et al. & 2006 & 2.66 & 1.53 & 1.13 & 67 & 89 & 15 & 15 & 18 & I \& II \\
\hline $\begin{array}{l}\text { de Sanctis \& } \\
\text { Zucchelli }\end{array}$ & 2006 & 3.82 & 0.18 & 3.64 & 97 & 99 & 40 & 40 & 36 & I \& II \\
\hline $\begin{array}{l}\text { Bittencourt et } \\
\text { al. }\end{array}$ & 2009 & 2.20 & 0.28 & 1.92 & 89 & 98 & 17 & 17 & 30 & I \\
\hline Cortellini et al. & 2009 & 2.4 & 0.8 & 1.60 & & 94 & 43.0 & 43.0 & 6.0 & I \& II \\
\hline Aroca et al. & 2009 & 2.5 & 0.2 & 2.30 & 92 & 99 & 20.0 & 67.0 & 6.0 & I \& II \\
\hline Zucchelli et al. & 2009 & 3.64 & 0.18 & 3.46 & 95 & 99 & 11.0 & 11.0 & 6.0 & I \\
\hline
\end{tabular}




\begin{tabular}{|l|c|c|c|c|c|c|c|c|c|c|}
\hline Zucchelli et al. & 2009 & 3.82 & 0.64 & 3.18 & 84 & 95 & 11.0 & 11.0 & 6.0 & I \\
\hline $\begin{array}{l}\text { Cardaropoli et } \\
\text { al. }\end{array}$ & 2009 & 2.7 & 0.2 & 2.50 & 93 & 99 & 16.0 & 10.0 & 6.0 & I \& II \\
\hline Zucchelli et al. & 2009 & 2.55 & 0.22 & 2.33 & 93 & 98 & 16.0 & 45.0 & 12.0 & I \& II \\
\hline Zucchelli et al. & 2009 & 2.59 & 0.1 & 2.49 & 97 & 99 & 16.0 & 47.0 & 12.0 & I \& II \\
\hline $\begin{array}{l}\text { Banihashemrad } \\
\text { et al. }\end{array}$ & 2009 & 3.64 & 1.64 & 2.00 & 57 & 88 & 7.0 & 11.0 & 6.0 & I \& II \\
\hline & & & & & & & & & & \\
\hline Count & 42 & & & & & & & & & \\
\hline Mean & & 3.18 & 0.75 & 2.42 & 79 & 94 & 19.05 & 23.86 & 13.71 & \\
\hline sd & & 0.56 & 0.56 & 0.59 & 14.65 & 4.08 & 13.24 & 18.85 & 16.26 & \\
\hline
\end{tabular}

\section{Clinical studies with Acellular Dermal Matrix Allograft (Alloderm)}

Dodge et al. (1998) was among the first to study acellular dermal matrix allograft (Alloderm) and its effect on root coverage in conjunction with a Bernimoulin (1975) CPF. Six patients with 18 recession sites were treated with Alloderm and a CPF. Mean root coverage obtained was $96 \%$ at 10 weeks. Thus, Alloderm could be used to cover recession defects with a CPF. Henderson et al. (2001) also examined the use of Alloderm and a CPF in root coverage surgery. The study focused on Alloderm's characteristic basement membrane on one side of the graft and connective tissue on the other side. Twenty patients with 20 Miller Class I and II recession sites were given an Alloderm graft in conjunction with a CPF in attempts to correct recession defects. The effects of the Alloderm basement membrane placement (facing osseous or flap) were evaluated. After a 12-month follow-up period, Henderson (2001) found a mean root coverage of $95 \%$. No statistical difference was seen between the Alloderm basement membrane placement. Paolantonio et al. (2002) studied 15 patients with 15 Miller Class I and II recession sites. Subjects received Alloderm in combination with a CPF and were followed for 12 months post-operatively. Mean baseline defect size was $4.8 \mathrm{~mm}$ and was reduced to $0.7 \mathrm{~mm}$ at final measurements for a mean root coverage of $83 \%$. Woodyard et al. (2004) 
complemented the use of Alloderm and a CPF in a study of 12 patients with 12 Miller Class I and II defects and obtained a mean root coverage of $99 \%$ after six months. Hirsch et al. (2005) elongated the post-operative period in a similar study using Alloderm and a CPF in 101 patients with 262 Miller Class I and II recession sites. The follow-up timeline lasted 24 months and mean root coverage obtained was $96 \%$. The increase in population size of this study greatly supported the use of Alloderm in root coverage procedures. Harris $(2000,2002,2004)$ also performed studies with longer post-operative follow-ups evaluating root coverage results of Alloderm and a CPF. The first of Harris' $(2000,2002)$ studies utilizing Alloderm and a CPF followed patients for three and 19 months, respectively. Mean root coverage obtained for the three month study was $96 \%$ and $87 \%$ for the 19 month study. Harris (2004) observed 25 patients with 57 Miller Class I and II recession sites over 49 months after they received root coverage surgery with Alloderm and a CPF. Mean root coverage obtained was $66 \%$.

Mean root coverage obtained from the above mentioned studies using Alloderm and a CPF was $81 \%$ (range $50-99 \%$; Table 7). Alloderm in combination with a Bernimoulin (1975) CPF created favorable results and is a suitable option for root coverage procedures. However, longer term follow-up studies are needed to further support this notion. 
Table 7

Acellular Dermal Matrix Allograft (Alloderm)

\begin{tabular}{|c|c|c|c|c|c|c|c|c|c|c|}
\hline Author & Year & Mean & Mean & Diff & $\underline{\underline{\mathbf{R p t}}}$ & $\frac{\text { Calc }}{\%}$ & \# Pts & $\begin{array}{c}\# \\
\text { Sites } \\
\end{array}$ & Time & Miller \\
\hline & & $\underline{\underline{\text { Init }}}$ & $\underline{\text { Fin }}$ & & $\underline{\text { Def }}$ & $\underline{\mathrm{Rt}}$ & & & $\underline{\text { Mo }}$ & Class \\
\hline & & & & & & & & & & \\
\hline \multicolumn{11}{|l|}{ Alloderm } \\
\hline Harris & 2000 & 3.10 & 0.20 & 2.90 & 96 & 99 & 25 & 65 & 3 & I \& II \\
\hline $\begin{array}{l}\text { Aichelmann- } \\
\text { Reidy et al. }\end{array}$ & 2001 & 2.50 & 0.80 & 1.70 & 66 & 94 & 22 & 22 & 6 & I \& II \\
\hline Henderson et al. & 2001 & 4.20 & 0.25 & 3.95 & 95 & 98 & 10 & 10 & 12 & I \& II \\
\hline Henderson et al. & 2001 & 3.70 & 0.15 & 3.55 & 95 & 99 & 10 & 10 & 12 & I \& II \\
\hline Novaes et al. & 2001 & 3.23 & 1.13 & 2.10 & 67 & 92 & 9 & 9 & 6 & I \& II \\
\hline Harris & 2002 & 3.10 & 0.40 & 2.70 & 87 & 97 & 20 & 47 & 19 & I \& II \\
\hline $\begin{array}{l}\text { Paolantonio et } \\
\text { al. }\end{array}$ & 2002 & 4.75 & 0.73 & 4.02 & 83 & 95 & 15 & 15 & 12 & I \& II \\
\hline Tal et al. & 2002 & 5.14 & 0.57 & 4.57 & 89 & 96 & 7 & 7 & 12 & I \& II \\
\hline Woodyard et al. & 2004 & 3.46 & 0.04 & 3.42 & 99 & 100 & 12 & 12 & 6 & I \& II \\
\hline Harris & 2004 & 3.20 & 1.10 & 2.10 & 66 & 92 & 25 & 57 & 49 & I \& II \\
\hline Barros et al. & 2004 & 3.40 & 1.30 & 2.10 & 64 & 90 & 14 & 32 & 6 & I \& II \\
\hline Barros et al. & 2004 & 3.90 & 0.90 & 3.00 & 79 & 93 & 14 & 32 & 6 & I \& II \\
\hline Cortes et al. & 2004 & 3.46 & 0.88 & 2.58 & 76 & 94 & 13 & 13 & 6 & I \\
\hline Mehlbauer & 2005 & 3.64 & 0.14 & 3.50 & 96 & 99 & 7 & 7 & 12 & I \& II \\
\hline Mehlbauer & 2005 & 3.57 & 0.07 & 3.50 & 98 & 99 & 7 & 7 & 12 & I \& II \\
\hline Santos et al. & 2005 & 2.58 & 0.62 & 1.96 & 74 & 95 & 12 & 26 & 12 & I \& II \\
\hline Hirsch et al. & 2005 & 4.20 & 0.20 & 4.00 & 96 & 99 & 101 & 262 & 24 & I \& II \\
\hline $\begin{array}{l}\text { de Queiroz } \\
\text { Cortes et al. }\end{array}$ & 2006 & 3.46 & 1.15 & 2.31 & 68 & 92 & 13 & 13 & 24 & I \\
\hline Rahmani et al. & 2006 & 4.05 & 1.15 & 2.90 & 72 & 92 & 10 & 10 & 6 & I \& II \\
\hline $\begin{array}{l}\text { Papageorgakopo } \\
\text { ulos }\end{array}$ & 2008 & 3.40 & 0.17 & 3.23 & 95 & 99 & 12 & 12 & 4 & I \& II \\
\hline $\begin{array}{l}\text { Papageorgakopo } \\
\text { ulos }\end{array}$ & 2008 & 3.10 & 0.67 & 2.44 & 78 & 95 & 12 & 12 & 4 & I \& II \\
\hline Joly et al. & 2007 & 4.20 & 2.10 & 2.10 & 50 & 85 & 10 & 10 & 6 & I \& II \\
\hline Felipe et al. & 2007 & 2.88 & 0.79 & 2.09 & 69 & 94 & 10 & 10 & 6 & I \& II \\
\hline Felipe et al. & 2007 & 2.73 & 0.41 & 2.32 & 85 & 97 & 10 & 10 & 6 & I \& II \\
\hline Andrade et al. & 2008 & 2.88 & 0.72 & 2.16 & 74 & 95 & 15 & 30 & 12 & I \& II \\
\hline Andrade et al. & 2008 & 2.73 & 0.46 & 2.27 & 83 & 97 & 15 & 30 & 12 & I \& II \\
\hline Haghighati et al. & 2009 & 2.93 & 0.41 & 2.52 & 85 & 97 & 16 & 16.0 & 6.0 & I \& II \\
\hline de Souza et al. & 2008 & 3.15 & 1.15 & 2.00 & & 92 & 7.0 & 13.0 & 12.0 & I \& II \\
\hline Shepherd et al. & 2009 & 3.6 & 1.0 & 2.60 & 70 & 93 & 9.0 & 9.0 & 4.0 & I \& II \\
\hline Count & 29 & & & & & & & & & \\
\hline Mean & & 3.46 & 0.68 & 2.78 & 81 & 95 & 15.93 & 27.86 & 10.92 & \\
\hline sd & & 0.63 & 0.47 & 0.76 & 13.02 & 3.46 & 17.08 & 47.49 & 9.13 & \\
\hline
\end{tabular}




\section{Histology of CTG}

Histology taken from CTGs used for root coverage vary from long junctional epithelium to regeneration (new bone, cementum, and connective tissue attachment to tooth). Harris (1999) completed studies that found both long junctional epithelium and regeneration. The first study (case report) utilized a CTG with a double pedicle flap. The

patient was followed for six months, after which time two teeth were extracted for prosthetic purposes and histology was taken. Results for one tooth revealed a long junctional epithelium while the other revealed repair (connective tissue adjacent to the tooth intermixed with epithelium). No new bone or cementum was seen in either tooth. In another study (case report) using a CTG with a double pedicle flap, Harris (1999) followed the patient for five months, after which the tooth had to be extracted due to a vertical root fracture and histology was taken. Results from one tooth revealed areas of regeneration. Bruno and Bowers (2000) also looked at the histologic attachment of soft tissue following root coverage with a CTG in a case report of one tooth. After a 12-month follow-up timeframe the majority of area of the covered defect showed connective tissue adhesion with fibers running parallel to the root. The connective tissue was highly vascularized. Goldstein (2001) found regeneration in a case study he completed. A CTG was used for root coverage on a 27 -year old female who was having her maxillary first premolar removed for orthodontic purposes. Fourteen months post-surgery the teeth were extracted and analyzed histologically. New connective tissue attachment and cementum were found. In a case report of a 24-year old needing a CTG for root coverage, Majzoub et al. (2001) evaluated histologic results 12 months post-surgically when teeth were extracted for orthodontic purposes. Healing largely revealed long junctional epithelium 
over the previously recessed site with minimal areas of new cementum in the apical region. No resorption nor ankylosis was present in any of the serial sections. Carnio et al. (2003) also reported the histology of a CTG used for root coverage in a case report. Two years after the defect was treated with a CTG the tooth was extracted. Histologic results revealed areas of dentinal resorption and formation of new bone in the deepest area of active resorption. Cummings et al. (2005) evaluated histologic differences in CTG or $\mathrm{ADM}$ with a $\mathrm{CPF}$ versus a $\mathrm{CPF}$ alone in four patients previously treatment planned for multiple extractions. Six months post-operatively the CTG and ADM showed areas of new cementum formation and unchanged osseous architecture. CTG revealed connective tissue fibers running parallel the root surface. The ADM showed new fibroblasts, vascularity and collagen components.

The above mentioned studies examined human histology only, no animal studies were evaluated. Controversy still exists as to whether soft tissue healing results in true regeneration. Many histologic studies are still needed to confirm or deny the concept that root coverage results in regeneration.

\section{Histology of CPF}

Gottlow et al. (1986) examined histology of the CPF in beagle dogs. Buccal recession was surgically created and notches made in the roots at the level of the gingival margin. Full thickness flaps were raised and coronally positioned. Three months postoperatively the dogs were sacrificed and the jaws sectioned for histologic evaluation. New connective tissue attachment was seen inserting into the root, with accompanying new cementum and osseous formation. Cummings et al. (2005), as mentioned above, 
reported histology in humans receiving CPFs which showed connective tissue fibers that were arranged parallel to the root surface rather than perpendicular. Elastin fibers were interspersed throughout the connective tissue and the osseous height was unchanged by the CPF.

\section{Histology of Alloderm}

Harris (1998) examined the histology of Alloderm used in root coverage in combination with a coronally positioned pedicle flap in a case report. Histology revealed the Alloderm had similar characteristics as the CTG used in another area of the mouth. Verhoeff's staining showed complete incorporation of the Alloderm into the connective tissue. Harris (2001) used Alloderm around implants in an attempt to increase the width of keratinized tissue. Histologic evaluation revealed a differentiation between the Alloderm and connective tissue. Cummings et al. (2005) compared CTG and Alloderm with a CPF in teeth previously treatment planned for extraction. Histologic findings revealed no differentiation between either CTG or Alloderm graft and the recipient connective tissue bed. However, original Alloderm elastin fibers were noted. New fibroblasts and vascular components were seen in the Alloderm. Alloderm and CTG also exhibited new cementum formation plus a combination of long junctional epithelium and connective tissue adhesion (connective tissue fibers were arranged parallel to the root). The alveolar crest was unchanged from the baseline height. 


\section{Creeping Attachment}

Goldman (1964) was the first to define the concept of creeping attachment in root coverage. Creeping attachment was defined as any coronal migration of the gingival margin following root coverage surgery, usually occurring one month to one year postoperatively. Thereafter, Ward (1974) reported on creeping attachment over the course of six months in his study 18 case reports. A frenectomy combined with a free gingival graft was used to increase the width of keratinized tissue. He found a creeping attachment of $0.74 \mathrm{~mm}(24 \%)$ at the final measurement. Matter (1980) studied free gingival grafts on ten patients over the course of 10 years with recession defects $<3 \mathrm{~mm}$. He also differentiated between bridging, initial root coverage, and creeping attachment. Mean root coverage obtained was $67 \%$ (10\% bridging, $57 \%$ creeping attachment). No change was seen between one and five years, supporting the concept that creeping attachment occurs between one month and one year post-operatively. Nelson (1987) treated 29 teeth with gingival recession in 14 patients with a CTG and pedicle flap. Patients were followed for 42 months. Mean root coverage obtained was $88 \%$ and some areas revealed a gain of 1-2 mm over the first year. Harris (1997) also studied creeping attachment in CTGs combined with a double pedicle flap. Nineteen patients with 22 recession sites were treated and followed for 12 months post-operatively. Mean root coverage obtained was $97.1 \%$, with mean creeping attachment of $0.8 \mathrm{~mm}$. Evidence of creeping attachment was found in $21 / 22$ defects $(95.5 \%)$ and $18 / 19$ patients $(94.7 \%)$. Creeping attachment contributed to complete root coverage in $17 / 22$ defects $(77.3 \%)$ and $15 / 19$ patients (78.9\%). In another study utilizing a CTG, Harris (2002) combined a CTG with either a double pedicle, coronally positioned, or lateral sliding flap. One hundred forty six Miller 
Class I and II recession sites in 100 patients were evaluated for short-term (13 weeks) and long-term (27.5 months) results. Mean root coverage obtained at 13 weeks was $97.1 \%$ and increased to $98.4 \%$ at 27.5 months. This study supported the concept of creeping attachment with the increase in root coverage over time.

While the abovementioned studies evaluated creeping attachment in CTGs, some articles reported creeping attachment with Alloderm. Henderson et al. (2001) used Alloderm for root coverage in 20 patients in comparing the placement of the basement membrane against the root or the tissue. Patients were seen weekly for the first four weeks, then every two weeks until eight weeks post-operatively, and then every three months until the final measurement at 12 months. Mean root coverage obtained was $95 \%$. No creeping attachment was seen after the second month post-operatively.

\section{The significance of tissue thickness in root coverage procedures}

Allen and Miller (1989) specifically described keys to increase predictability for root coverage using the CPF: 1) Miller Class I recession, 2) $\geq 3 \mathrm{~mm}$ keratinized tissue, and 3) $\geq 1 \mathrm{~mm}$ gingival thickness. This study was among the first to emphasize the importance of thick tissue for root coverage. Harris (1997) also recognized the impact that tissue thickness had on results of root coverage when he studied patients treated with CTG and double pedicle or GTR. Patients were further subdivided into two groups (thick vs. thin tissue). Tissue thickness in patients treated with the CTG did not have a significant difference on the outcome. However, mean root coverage obtained for patients with thin tissue in the GTR group was $26.7 \%$ and $95.9 \%$ for patients with thick tissue. 
Baldi et al. (1999) studied the influence of flap thickness on root coverage results in 19 patients with 19 recession defects $\geq 2 \mathrm{~mm}$ treated with a CPF. Flaps with a thickness $\geq 0.8 \mathrm{~mm}$ had $100 \%$ root coverage. Flaps with $<0.8 \mathrm{~mm}$ thickness resulted in $<$ $100 \%$ root coverage. Thus, a correlation was evident between flap thickness and root coverage obtained.

Studies mentioned previously revealed that when grafts are used in root coverage, tissue thickness increased and the gingival margin remained stable long-term. It can be deduced, therefore, that thicker tissue aided in resolving and preventing future recession. 


\section{CHAPTER II}

\section{METHODS}

Study Design. Twenty-four patients with at least 1 site with a Miller Class I or II recession defect $\geq 3 \mathrm{~mm}$ received root coverage surgery and were followed for a period of 6 months. Twelve patients in the positive control group were treated with a coronally positioned tunnel, acellular dermal matrix allograft, and continuous sling suture (Continuous). The test group consisted of 12 patients who were treated with a coronally positioned tunnel, acellular dermal matrix allograft, and a single tooth sling suture (Single). The surgical technique for both the control and test groups was based on the coronally positioned tunnel procedure described by Allen (E. P. Allen, Center for Advanced Dental Education, Dallas, TX; course manual). Sutures used for both test and control groups were resorbable Maxon 5-0, 3/8 circle $13 \mathrm{~mm}$ needle for the allograft and PTFE 4-0, 3/8 circle $13.1 \mathrm{~mm}$ needle for the soft tissue. Patients were randomly assigned to the Single or Continuous treatment group using a coin toss. All surgical procedures were completed by one operator (CS) under the direction of one mentor (HG). The surgeon was trained in the procedures until considered proficient. All measurements were performed by a blinded examiner $(\mathrm{JH})$. The mentor performed the coin toss and verified the measurements taken by the blinded examiner. The treatment was not revealed to the blinded examiner. All patients signed an informed consent approved by 
the University of Louisville Institutional Review Board. The study was conducted between September 1, 2009 and May 31, 2010 in the Graduate Periodontics clinic at the University of Louisville.

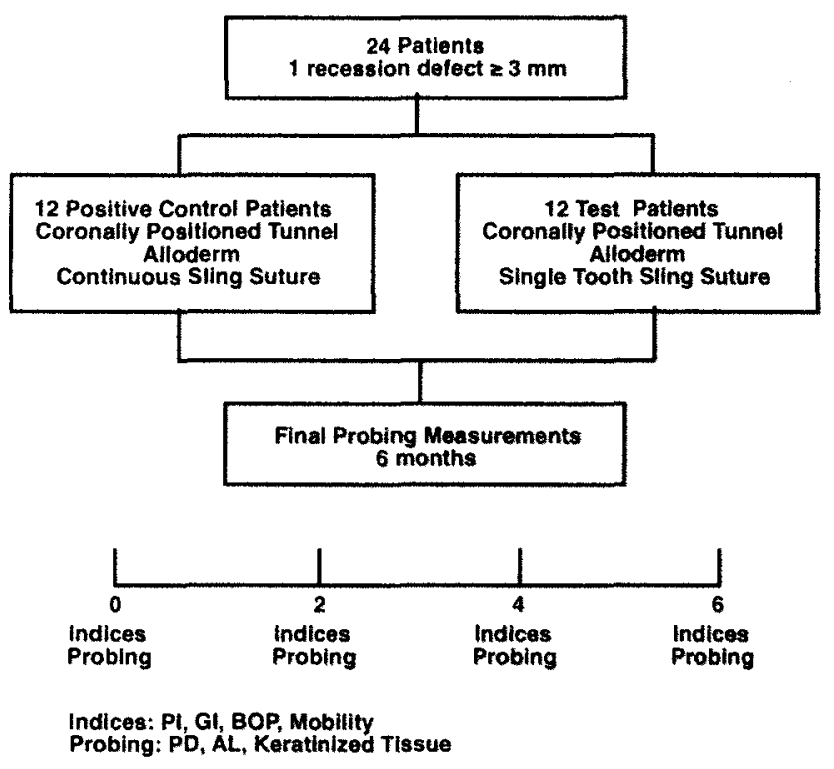

Inclusion Criteria. Inclusion criteria were: 1) at least one Miller Class I or II recession defect $\geq 3 \mathrm{~mm}$ (Miller 1985) on a non-molar tooth; 2) the patient must be between 18 and 90 years of age.

Exclusion Criteria. Exclusion criteria were: 1) debilitating systemic or infectious diseases (HIV or hepatitis) or any diseases that affect the periodontium; 2) a known allergy to any of the materials used in the study; 3) requirement for antibiotic prophylaxis; 4) CEJ not identifiable; 5) a root surface restoration at the recession site; 6) failure to maintain an oral hygiene level of at least $80 \%$ plaque free surfaces; 7) 
pregnancy or lactation; 8) use of tobacco products through smoking or a smokeless tobacco habit; 9) alcohol abuse problems; 10) long-term steroid therapy; 11) history of a previous root coverage procedure, graft or GTR involving the recession site; 12) failure to complete the informed consent.

Pre-surgical Treatment. Each patient received a full diagnostic work-up including periapical and bite-wing radiographs of the recession site, study casts, intraoral photographs, and a full mouth clinical examination to record clinical attachment level, probing depth, recession, keratinized tissue width, and tooth mobility. All women of childbearing age received a pregnancy test. Detailed oral hygiene instructions were provided.

Baseline data included the following: 1) Miller classification of the recession defects (Miller 1985, Appendix C); 2) Plaque index (Silness and Loe 1964, Appendix D); 3) Gingival index (Lobene 1986, Appendix E); 4) Bleeding on probing using dichotomous scoring (Appendix F); 5) Gingival margin levels (Recession) measured from the CEJ to the gingival margin; 6) Keratinized tissue measured from the gingival margin to the mucogingival junction (Appendix G); 7) Clinical attachment level measured from the CEJ to the bottom of the clinical periodontal pocket; 8) Tooth mobility measured using a modification of the Miller's index (Laster et al. 1975, Appendix $\mathrm{H}$ ); 9) Creeping attachment measured from the $\mathrm{CEJ}$ to the gingival margin starting at 8 weeks post-surgery until the 6-month final examination (Appendix I); 10) Tooth vitality tested using an electric pulp tester and a cold test; 11) Radiographic examination utilizing a paralleling technique included a pre-operative periapical and bitewing X-ray; 12) Patient models; 13) Clinical photographs. 
Surgical Treatment. Pre-surgical measurements were made prior to determining the treatment modality (Appendix A). Probing depth, keratinized tissue width, and gingival margin level was measured prior to anesthesia. The soft tissue recession defect was also measured horizontally and vertically at the level of the CEJ and $1 \mathrm{~mm}$ coronal to the gingival margin. Following administration of local anesthesia, and reflection of a flap, the distance from the CEJ to the alveolar crest was measured at the mid-facial and at the mesial and distal interproximal. Defect width was measured horizontally at the level of the interproximal osseous crest level and $1.0 \mathrm{~mm}$ coronal to the defect base (Appendix B). Prior to the incisions, the root surface was meticulously root planed using ultrasonic and hand instruments to obtain a smooth, hard root surface.

Sites were treated with a coronally positioned tunnel procedure without any vertical releasing incisions (E. P. Allen, Center for Advanced Dental Education, Dallas, TX; course manual). The tissue was elevated using a split thickness technique beyond the mucogingival junction and extended apically until enough release was obtained to permit adequate coronal positioning. The tunnel was extended at least one tooth mesial and distal to the recession site. Interproximal papilla were elevated off the interproximal septum, for both the facial and lingual, to facilitate coronal positioning. The acellular dermal matrix allograft was positioned at the CEJ and extended approximately $3 \mathrm{~mm}$ beyond the osseous defect margins. Either a single tooth or continuous sling suture was used to secure the graft (Maxon, Kendall Healthcare, Mansfield, MA 02048). The flap margin was positioned as coronal to the $\mathrm{CEJ}$ as possible to completely cover the defect and the acellular dermal matrix. The flap was sutured with either a single tooth or continuous line angle sling suture (PTFE, Osteogenics Biomedical, Lubbock, TX, 
79424). Any papilla that was incised during the surgery was closed with an interrupted suture.

Post-operative instructions were given along with the following prescriptions: 1) systemic doxycycline hyclate $100 \mathrm{mg}$ once a day for 14 days; 2) naproxen $375 \mathrm{mg} \mathrm{q12h}$ for 7 days; 3) Vicodin ES q6-8h prn pain 4) Medrol dose pack of 21 tablets of $4 \mathrm{mg}$ methylprednisolone; 6 tablets on day 1, 5 on day 2 , decrease by 1 per day until the last 1 tablet dose on day 6; or dexamethasone 18 one mg tablets taken 3 tablets per day for 1 st 3 days, then 2 per day for the next 3 days, then 1 per day for the last 3 days always taken in the morning; and 5) chlorhexidine digluconate $0.12 \%$ applied twice daily, locally in the surgical site, until the end of the study period.

Post-Surgical Management. All patients were seen weekly for 2 weeks, then every two weeks until 8 weeks post-operatively, and then every two months until the end of the study period ( 6 months). Suture removal took place at 4 weeks. Post-operative visits consisted of supragingival plaque removal and oral hygiene reinforcement. Any patient who developed an adverse reaction to the materials used or showed attachment loss greater than or equal to $2.0 \mathrm{~mm}$ were exited from the study to receive the appropriate treatment.

Eight weeks post-operatively was considered the baseline for the measurement of creeping attachment. Creeping attachment was measured at 2 months and at the 6-month final examination (see Appendix I).

Six-Month Evaluation. At the end of the 6-month evaluation period all baseline clinical measurements were repeated. 
Calibration. All measurements were made with a $15 \mathrm{~mm}$ North Carolina probe by a blinded examiner. Intra-examiner reliability was established by at least 2 exams on 3 patients to achieve $70 \%$ exact measurements and $90 \%$ of measurements within $1.0 \mathrm{~mm}$.

Statistical Analysis. Means and standard deviations were calculated for all parameters. A paired t-test was used to evaluate the statistical significance of the differences between initial and final data. An unpaired t-test was used to evaluate statistical differences between the test and control groups. The sample size of 12 per group gave $90 \%$ statistical power to detect a difference of $1 \mathrm{~mm}$ defect coverage between groups. Power calculations were based on data from previous studies. 


\section{CHAPTER III}

\section{RESULTS}

A total of 7 females and 5 males with a mean age of $41 \pm 13$, ranging from 20 to 62, were enrolled in the Single group while 7 females and 5 males with a mean age of $42 \pm$ 14 , ranging from 24 to 65 , were enrolled in the Continuous group. The Single group consisted of 1 maxillary lateral incisor, 2 maxillary canines, 2 maxillary premolars, 1 mandibular lateral incisor and 6 mandibular premolars. The Continuous group consisted of 1 maxillary canine, 3 maxillary premolars, 1 mandibular central incisor, 2 mandibular canines and 5 mandibular premolars. There were no smokers enrolled in either group.

Clinical Indices. The mean Plaque Index (Silness and Loe 1964) was initially low and slightly decreased by 6 months for both the Single and the Continuous groups. There was a statistically significant difference from initial to 6-month values for the Single group $(p<0.05)$ but there were no statistically significant differences between groups ( $p>0.05$, Table 8). The mean Gingival index (Lobene 1986) was approximately 1.0 initially and decreased to about 0.3 at 6 months for both the Single and the Continuous groups $(\mathrm{p}<0.05)$. There were no statistically significant differences between groups $(\mathrm{p}>0.05)$. There was minimal bleeding on probing at the initial and the 6-month time point. Mobility (Laster et al. 1975) was low initially and at 6 months for both the 
Single and the Continuous groups $(\mathrm{p}>0.05)$. There were no statistically significant differences between groups $(\mathrm{p}>0.05)$.

Probing Measurements. Mean probing depth was approximately $1 \mathrm{~mm}$ initially and at 6 months for both the Single and Continuous groups. There was a statistically significant difference from initial to 6 -month value for the Continuous group $(p<0.05)$, however, there were no statistically significant differences between groups $(p>0.05$, Table 9). The mean clinical attachment level was 4 to $5 \mathrm{~mm}$ initially but improved significantly by time $6(\mathrm{p}<0.05)$ due to the amount of defect coverage. There were no statistically significant differences between groups $(p>0.05)$. Mean keratinized tissue was initially about $2 \mathrm{~mm}$ and there was minimal change for both groups ( $p>0.05$, Table 9). There were statistically significant differences between groups $(p>0.05)$.

Creeping Attachment. Creeping attachment, or the mean recession change from 2 to 6 months in this study, showed an increase in recession of approximately $0.1 \mathrm{~mm}$ for both groups $(p>0.05)$. There were no statistically significant differences between groups $(\mathrm{p}>0.05$, Table 10$)$.

Osseous Dehiscence. The mean facial dehiscence defect depth at the initial exam was approximately $6.4 \mathrm{~mm}$ for the Single group and $4.8 \mathrm{~mm}$ for the Continuous group $(\mathrm{p}$ $<0.05$, Table 11).

Gingival Recession. The mean facial recession defect at the initial exam for the Single group was $3.4 \pm 0.6 \mathrm{~mm}$ which was reduced to $0.8 \pm 0.8 \mathrm{~mm}$ at 6 months for defect coverage of $2.5 \pm 0.7 \mathrm{~mm}$ or $76 \%(\mathrm{p}<0.05$, Table 12). For the Continuous group, mean initial recession was $3.0 \pm 0.0 \mathrm{~mm}$ which was reduced to $0.5 \pm 0.8 \mathrm{~mm}$ at 6 months for defect coverage of $2.5 \pm 0.8 \mathrm{~mm}$ or $83 \%(\mathrm{p}<0.05$, Table 13). Mean root coverage, or 
the percentage of the root that was covered, rather than the recession defect, was $94 \%$ for the Single group and $96 \%$ for the Continuous group. Frequency data indicated that the predictability of obtaining $\geq 90 \%$ defect coverage was $58 \%$ or 7 of 12 sites for the Continuous group, while for the Single group it was 33\% or 4 of 12 sites (Tables 12 and 13).

Results of maxillary and mandibular defect coverage for test and control sites are listed in Table 14 and 15, respectively. Data from previous $U$ of $L$ studies are pooled for results for maxillary (Table 16,20) and mandibular (Table 17, 21) sites; defect coverage and by the amount of keratinized tissue for maxillary (Table 18) and mandibular (Table 19) sites; keratinized tissue gain, including non- $U$ of $L$ studies (Table 22); creeping attachment, including non- $U$ of $L$ studies (Table 23); summary of $U$ of $L$ coronally positioned flap surgeries (Table 24); summary of $U$ of $L$ coronally positioned tunnel surgeries (Table 25); summary of maxillary and mandibular results for coronally positioned tunnel surgeries (Table 26) and summary of total defect coverage for maxillary and mandibular tunnel procedures (Table 27). 
Table 8

Clinical Indices for Test and Control Sites

Mean \pm sd

\begin{tabular}{|cccccc|}
\hline & & n & Initial & 6 Month & Change \\
\hline \hline Plaque & Sing & 12 & $0.6 \pm 0.6$ & $0.2 \pm 0.3$ & $0.4 \pm 0.5^{*}$ \\
Index & Cont & 12 & $0.4 \pm 0.3$ & $0.2 \pm 0.2$ & $0.2 \pm 0.3$ \\
\hline $\begin{array}{c}\text { Gingival } \\
\text { Index }\end{array}$ & Sing & 12 & $0.9 \pm 0.5$ & $0.3 \pm 0.3$ & $0.6 \pm 0.3^{*}$ \\
\hline $\begin{array}{c}\text { Bleeding } \\
\text { on }\end{array}$ & Sont & 12 & $0.8 \pm 0.2$ & $0.3 \pm 0.3$ & $0.5 \pm 0.3^{*}$ \\
\hline $\begin{array}{c}\text { Probing } \\
\text { Mobility }\end{array}$ & Cont & 12 & $0.1 \pm 0.2$ & $0.0 \pm 0.1$ & $0.1 \pm 0.1$ \\
& Sing & 12 & $0.0 \pm 0.1$ & $0.0 \pm 0.0$ & $0.0 \pm 0.1$ \\
\hline
\end{tabular}

$*=\mathrm{p}<0.05$ initial to 6 month values

Sing $=$ Single tooth sling suture

Cont $=$ Continuous sling suture 


\section{Table 9}

Probing Measurements for Test and Control Sites

$\underline{\text { Mean } \pm \mathrm{sd}(\mathrm{mm})}$

\begin{tabular}{|cccccc|}
\hline & & n & Initial & 6 Month & Change \\
\hline Probing & Sing & 12 & $1.2 \pm 0.4$ & $1.3 \pm 0.3$ & $0.1 \pm 0.4$ \\
Depth & Cont & 12 & $1.1 \pm 0.3$ & $1.3 \pm 0.4$ & $0.2 \pm 0.3^{*}$ \\
\hline $\begin{array}{c}\text { Clinical } \\
\text { Attachment } \\
\text { Level }\end{array}$ & Sing & 12 & $4.5 \pm 0.6$ & $2.1 \pm 0.9$ & $2.4 \pm 0.8^{*}$ \\
\hline Cont & 12 & $4.1 \pm 0.3$ & $1.8 \pm 0.8$ & $2.3 \pm 0.8^{*}$ \\
Keratinized & Sing & 12 & $2.0 \pm 0.7$ & $2.3 \pm 1.2$ & $0.3 \pm 0.8$ \\
Tissue & Cont & 12 & $2.3 \pm 1.0$ & $2.3 \pm 0.9$ & $0.0 \pm 0.6$ \\
\hline
\end{tabular}

$* \mathrm{p}<0.05$ initial to 6 month values

Sing $=$ Single tooth sling suture

Cont $=$ Continuous sling suture 


\section{Table 10}

Creeping Attachment Mid-buccal

Mean $\pm \mathrm{sd}(\mathrm{mm})$

\begin{tabular}{|cccccc|}
\hline & & n & 2 Month & 6 Month & Change \\
\hline \hline Creeping & Sing & 12 & $0.6 \pm 1.0$ & $0.7 \pm 0.8$ & $0.1 \pm 0.5$ \\
Attachment & Cont & 12 & $0.4 \pm 0.6$ & $0.5 \pm 0.8$ & $0.1 \pm 0.6$ \\
\hline
\end{tabular}

Sing $=$ Single tooth sling suture

Cont $=$ Continuous sling suture 


\section{Table 11}

$\underline{\text { Recession depth vs. dehiscence depth }}$

Mean \pm sd $(\mathrm{mm})$

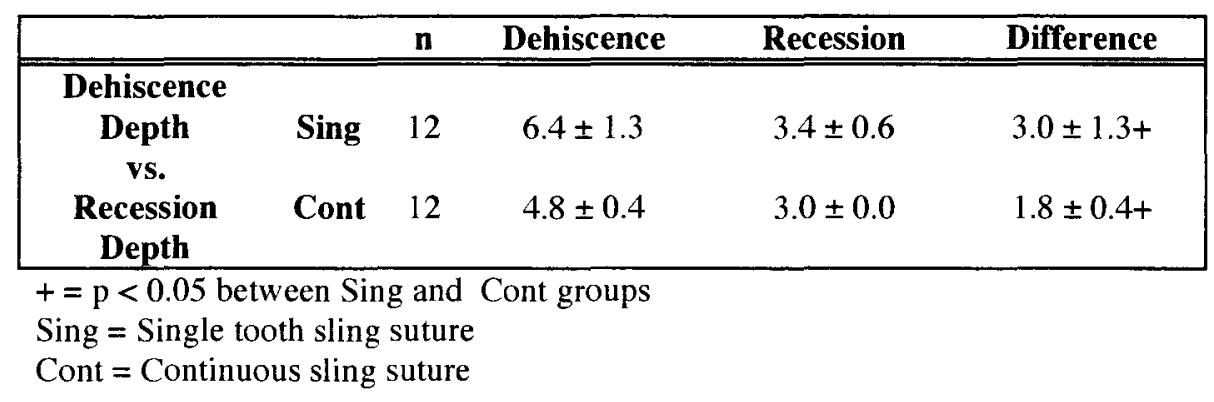




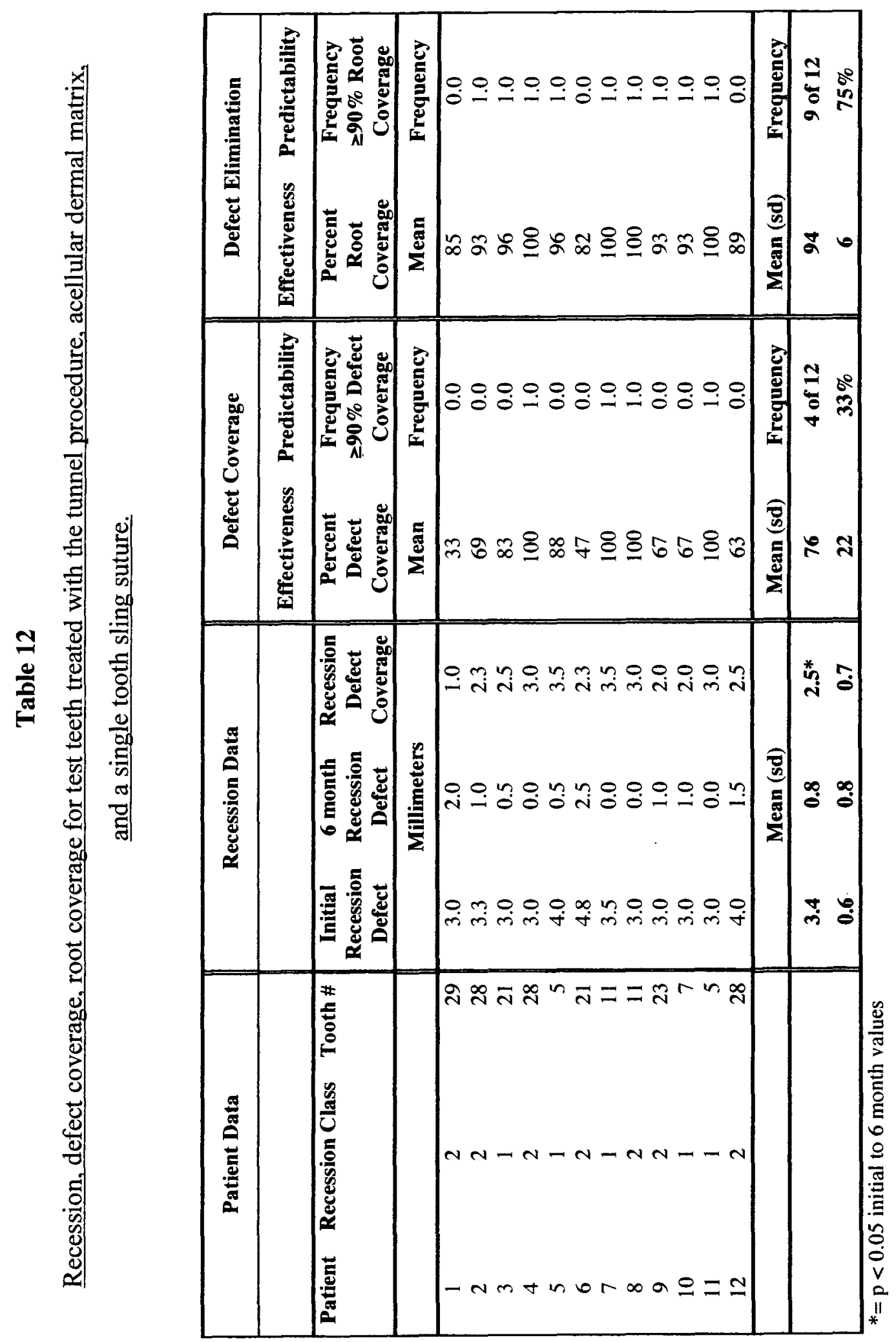



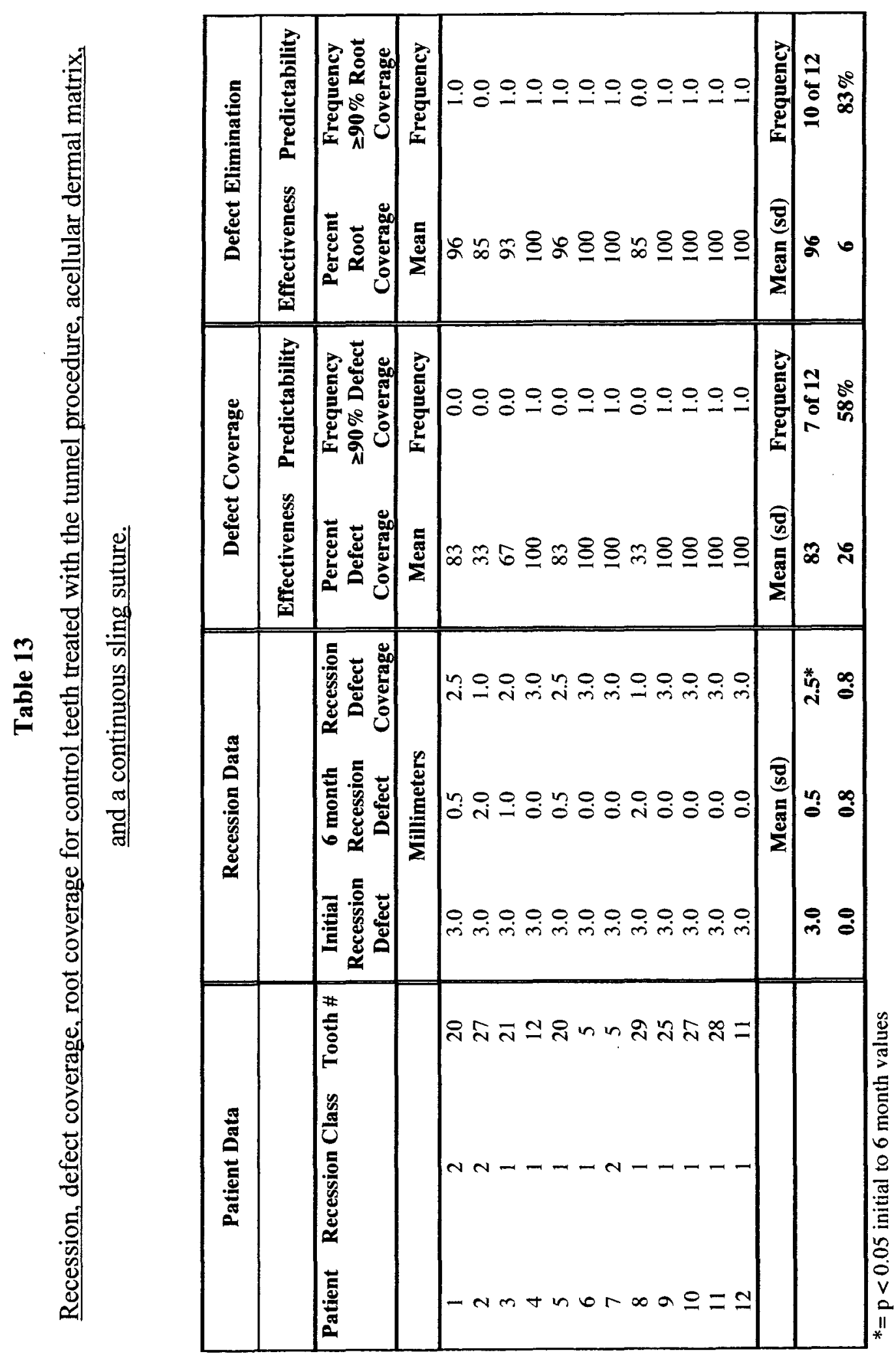


\section{Table 14}

Results of Maxillary Arch Data by Treatment Group

Mean \pm sd

\begin{tabular}{|c|c|c|c|c|c|}
\hline Patient & Group & Tooth & $\operatorname{Rec} 0$ & Rec 6 & Change \\
\hline \multicolumn{6}{|c|}{ Single Tooth Sling Suture } \\
\hline 1 & Single & 5 & 4.0 & 0.5 & 3.5 \\
\hline 2 & Single & 11 & 3.5 & 0.0 & 3.5 \\
\hline 3 & Single & 11 & 3.0 & 0.0 & 3.0 \\
\hline 4 & Single & 7 & 3.0 & 1.0 & 2.0 \\
\hline 5 & Single & 5 & 3.0 & 0.0 & 3.0 \\
\hline Mean & & & $\mathbf{3 . 3 0}$ & $\mathbf{0 . 3 0}$ & $\mathbf{3 . 0 0}$ \\
\hline sd & & & 0.45 & 0.45 & 0.61 \\
\hline Percent & efect Cover: & & & & $91 \%$ \\
\hline \multicolumn{6}{|c|}{ Continuous Sling Suture } \\
\hline 1 & Continuous & 12 & 3.0 & 0.0 & 3.0 \\
\hline 2 & Continuous & 5 & 3.0 & 0.0 & 3.0 \\
\hline 3 & Continuous & 5 & 3.0 & 0.0 & 3.0 \\
\hline 4 & Continuous & 11 & 3.0 & 0.0 & 3.0 \\
\hline \multirow{3}{*}{\multicolumn{3}{|c|}{$\begin{array}{l}\text { Mean } \\
\text { sd } \\
\text { Percent Defect Coverage }\end{array}$}} & $\mathbf{3 . 0 0}$ & 0.00 & $\mathbf{3 . 0 0}$ \\
\hline & & & 0.00 & 0.00 & 0.00 \\
\hline & & & & & $100 \%$ \\
\hline
\end{tabular}


Table 15

Results of Mandibular Arch Data by Treatment Group

Mean $\pm \mathrm{sd}$

\begin{tabular}{|c|c|c|c|c|c|}
\hline Patient & Group & Tooth & $\operatorname{Rec} 0$ & Rec 6 & Change \\
\hline \multicolumn{6}{|c|}{ Single Tooth Sling Suture } \\
\hline 1 & Single & 29 & 3.0 & 2.0 & 1.0 \\
\hline 2 & Single & 28 & 3.3 & 1.0 & 2.3 \\
\hline 3 & Single & 21 & 3.0 & 0.5 & 2.5 \\
\hline 4 & Single & 28 & 3.0 & 0.0 & 3.0 \\
\hline 5 & Single & 21 & 4.8 & 2.5 & 2.3 \\
\hline 6 & Single & 23 & 3.0 & 1.0 & 2.0 \\
\hline 7 & Single & 28 & 4.0 & 1.5 & 2.5 \\
\hline Mean & & & 3.43 & 1.21 & 2.21 \\
\hline & & & 0.69 & 0.86 & 0.62 \\
\hline Percent & Defect Cover: & & & & $65 \%$ \\
\hline \multicolumn{6}{|c|}{ Continuous Tooth Sling Suture } \\
\hline 1 & Continuous & 20 & 3.0 & 0.5 & 2.5 \\
\hline 2 & Continuous & 27 & 3.0 & 2.0 & 1.0 \\
\hline 3 & Continuous & 21 & 3.0 & 1.0 & 2.0 \\
\hline 4 & Continuous & 20 & 3.0 & 0.5 & 2.5 \\
\hline 5 & Continuous & 29 & 3.0 & 2.0 & 1.0 \\
\hline 6 & Continuous & 25 & 3.0 & 0.0 & 3.0 \\
\hline 7 & Continuous & 27 & 3.0 & 0.0 & 3.0 \\
\hline 8 & Continuous & 28 & 3.0 & 0.0 & 3.0 \\
\hline \multirow{3}{*}{\multicolumn{3}{|c|}{$\begin{array}{l}\text { Mean } \\
\text { sd } \\
\text { Percent Defect Coverage }\end{array}$}} & 3.00 & 0.75 & 2.25 \\
\hline & & & 0.00 & 0.85 & 0.85 \\
\hline & & & & & $75 \%$ \\
\hline
\end{tabular}


Table 16

Results of Maxillary Arch Data Pooled from 3 U of L Studies

$\underline{\text { Mean } \pm \text { sd }}$

\begin{tabular}{|llrrrr|}
\hline Number & Arch/Study & Tooth & \multicolumn{1}{l}{ Rec 0 } & Rec 6 & Change \\
\hline 1 & Max CS & 5 & 4.0 & 0.5 & 3.5 \\
2 & Max CS & 11 & 3.5 & 0.0 & 3.5 \\
3 & Max CS & 11 & 3.0 & 0.0 & 3.0 \\
4 & Max CS & 7 & 3.0 & 1.0 & 2.0 \\
5 & Max CS & 5 & 3.0 & 0.0 & 3.0 \\
6 & Max CS & 12 & 3.0 & 0.0 & 3.0 \\
7 & Max CS & 5 & 3.0 & 0.0 & 3.0 \\
8 & Max CS & 5 & 3.0 & 0.0 & 3.0 \\
9 & Max CS & 11 & 3.0 & 0.0 & 3.0 \\
10 & Max GP & 12 & 4.0 & 0.0 & 4.0 \\
11 & Max GP & 13 & 3.0 & 0.0 & 3.0 \\
12 & Max GP & 5 & 3.0 & 0.5 & 2.5 \\
13 & Max GP & 5 & 3.0 & 0.0 & 3.0 \\
14 & Max GP & 11 & 3.0 & 0.5 & 2.5 \\
15 & Max GP & 6 & 3.0 & 0.0 & 3.0 \\
16 & Max NS & 12 & 3.0 & 0.0 & 3.0 \\
17 & Max NS & 6 & 6.0 & 0.0 & 6.0 \\
18 & Max NS & 11 & 3.0 & 0.0 & 3.0 \\
\hline Mean & Maxillary & & $\mathbf{3 . 3}$ & $\mathbf{0 . 1}$ & $\mathbf{3 . 2}$ \\
sd & & & $\mathbf{0 . 7}$ & $\mathbf{0 . 3}$ & $\mathbf{0 . 8}$ \\
Percent Defect Coverage & & & & $\mathbf{9 6 \%}$ \\
\hline
\end{tabular}


Table 17

Results of Mandibular Arch Data Pooled from 3 U of L Studies

Mean \pm sd

\begin{tabular}{|llrrrr|}
\hline Number & Arch/Study & Tooth & Rec 0 & Rec 6 & Change \\
\hline 1 & Mand CS & 29 & 3.0 & 2.0 & 1.0 \\
2 & Mand CS & 28 & 3.3 & 1.0 & 2.3 \\
3 & Mand CS & 21 & 3.0 & 0.5 & 2.5 \\
4 & Mand CS & 28 & 3.0 & 0.0 & 3.0 \\
5 & Mand CS & 21 & 4.8 & 2.5 & 2.3 \\
6 & Mand CS & 23 & 3.0 & 1.0 & 2.0 \\
7 & Mand CS & 28 & 4.0 & 1.5 & 2.5 \\
8 & Mand CS & 20 & 3.0 & 0.5 & 2.5 \\
9 & Mand CS & 27 & 3.0 & 2.0 & 1.0 \\
10 & Mand CS & 21 & 3.0 & 1.0 & 2.0 \\
11 & Mand CS & 20 & 3.0 & 0.5 & 2.5 \\
12 & Mand CS & 29 & 3.0 & 2.0 & 1.0 \\
13 & Mand CS & 25 & 3.0 & 0.0 & 3.0 \\
14 & Mand CS & 27 & 3.0 & 0.0 & 3.0 \\
15 & Mand CS & 28 & 3.0 & 0.0 & 3.0 \\
16 & Mand GP & 27 & 3.0 & 2.3 & 0.8 \\
17 & Mand GP & 21 & 3.0 & 0.0 & 3.0 \\
18 & Mand GP & 22 & 3.3 & 2.0 & 1.3 \\
19 & Mand GP & 25 & 3.0 & 2.0 & 1.0 \\
20 & Mand GP & 29 & 3.0 & 0.8 & 2.3 \\
21 & Mand GP & 26 & 3.0 & 0.0 & 3.0 \\
22 & Mand NS & 20 & 3.0 & 2.0 & 1.0 \\
23 & Mand NS & 21 & 4.0 & 2.0 & 2.0 \\
24 & Mand NS & 25 & 3.5 & 1.0 & 2.5 \\
25 & Mand NS & 28 & 4.0 & 2.5 & 1.5 \\
26 & Mand NS & 28 & 3.0 & 1.0 & 2.0 \\
26 & Mand NS & 29 & 3.0 & 1.0 & 2.0 \\
\hline Mean & Mandibular & & $\mathbf{3 . 2}$ & $\mathbf{1 . 2}$ & $\mathbf{2 . 0}$ \\
sd & & & $\mathbf{0 . 4}$ & $\mathbf{0 . 9}$ & $\mathbf{0 . 7}$ \\
Percent Defect Coverage & & & & $\mathbf{6 4 \%}$ \\
\hline
\end{tabular}


Table 18

Results of Maxillary Arch Data Pooled from $3 \mathrm{U}$ of L Studies

Stratified by Keratinized Tissue Width $<2 \mathrm{~mm}$ and $\geq 2 \mathrm{~mm}$

Mean \pm sd

\begin{tabular}{|c|c|c|c|c|c|c|}
\hline Patient & Arch/Study & $\mathbf{T} \#$ & KT O & $\operatorname{Rec} 0$ & $\operatorname{Rec} 6$ & Change \\
\hline \multicolumn{7}{|c|}{$<2 \mathrm{~mm}$ Keratinized Tissue } \\
\hline 1 & Max GP & 12 & 0.5 & 4.0 & 0.0 & 4.0 \\
\hline 2 & Max GP & 5 & 1.0 & 3.0 & 0.0 & 3.0 \\
\hline 3 & Max CS & 11 & 1.3 & 3.0 & 0.0 & 3.0 \\
\hline 4 & Max CS & 5 & 1.5 & 3.0 & 0.0 & 3.0 \\
\hline 5 & Max GP & 11 & 1.5 & 3.0 & 0.5 & 2.5 \\
\hline 6 & Max NS & 6 & 1.5 & 6.0 & 0.0 & 6.0 \\
\hline 7 & Max NS & 11 & 1.5 & 3.0 & 0.0 & 3.0 \\
\hline 8 & Max CS & 11 & 1.8 & 3.0 & 0.0 & 3.0 \\
\hline Mean & & & 1.3 & 3.5 & 0.1 & 3.4 \\
\hline sd & & & 0.4 & 1.1 & 0.2 & 1.1 \\
\hline Percent & ect Coverage & & & & & $98 \%$ \\
\hline \multicolumn{7}{|c|}{$\geq 2 \mathrm{~mm}$ Keratinized Tissue } \\
\hline 1 & Max CS & 5 & 2.0 & 4.0 & 0.5 & 3.5 \\
\hline 2 & $\operatorname{Max}$ GP & 13 & 2.0 & 3.0 & 0.0 & 3.0 \\
\hline 3 & Max GP & 6 & 2.0 & 3.0 & 0.0 & 3.0 \\
\hline 4 & Max NS & 12 & 2.0 & 3.0 & 0.0 & 3.0 \\
\hline 5 & Max CS & 12 & 2.5 & 3.0 & 0.0 & 3.0 \\
\hline 6 & Max CS & 11 & 3.0 & 3.5 & 0.0 & 3.5 \\
\hline 7 & Max GP & 5 & 3.0 & 3.0 & 0.5 & 2.5 \\
\hline 8 & Max CS & 5 & 3.5 & 3.0 & 0.0 & 3.0 \\
\hline 9 & Max CS & 5 & 4.5 & 3.0 & 0.0 & 3.0 \\
\hline 10 & Max CS & 7 & 5.0 & 3.0 & 1.0 & 2.0 \\
\hline Mean & & & 3.0 & 3.2 & 0.2 & 3.0 \\
\hline sd & & & 1.1 & 0.3 & 0.4 & 0.4 \\
\hline Percent & et Coverage & & & & & $94 \%$ \\
\hline
\end{tabular}


Table 19

Results of Mandibular Arch Data Pooled from 3 U of L Studies

Stratified by Keratinized Tissue Width $<2 \mathrm{~mm}$ and $\geq 2 \mathrm{~mm}$

$\underline{\text { Mean } \pm s d}$

\begin{tabular}{|c|c|c|c|c|c|c|}
\hline Patient & Arch/Study & Tooth & KT & $\operatorname{Rec} 0$ & Rec 6 & Change \\
\hline \multicolumn{7}{|c|}{$<2 \mathrm{~mm}$ Keratinized Tissue } \\
\hline 1 & Mand GP & 27 & 0.5 & 3.0 & 2.3 & 0.8 \\
\hline 2 & Mand GP & 25 & 0.5 & 3.0 & 2.0 & 1.0 \\
\hline 3 & Mand GP & 26 & 0.5 & 3.0 & 0.0 & 3.0 \\
\hline 4 & Mand NS & 21 & 0.5 & 4.0 & 2.0 & 2.0 \\
\hline 5 & Mand NS & 29 & 0.5 & 3.0 & 1.0 & 2.0 \\
\hline 6 & Mand CS & 28 & 1.0 & 3.3 & 1.0 & 2.3 \\
\hline 7 & Mand CS & 21 & 1.0 & 4.8 & 2.5 & 2.3 \\
\hline 8 & Mand GP & 21 & 1.0 & 3.0 & 0.0 & 3.0 \\
\hline 9 & Mand GP & 22 & 1.0 & 3.3 & 2.0 & 1.3 \\
\hline 10 & Mand NS & 20 & 1.0 & 3.0 & 2.0 & 1.0 \\
\hline 11 & Mand NS & 25 & 1.0 & 3.5 & 1.0 & 2.5 \\
\hline 12 & Mand NS & 28 & 1.0 & 4.0 & 2.5 & 1.5 \\
\hline 13 & Mand CS & 29 & 1.3 & 3.0 & 2.0 & 1.0 \\
\hline 14 & Mand CS & 27 & 1.3 & 3.0 & 2.0 & 1.0 \\
\hline 15 & Mand GP & 29 & 1.5 & 3.0 & 0.8 & 2.3 \\
\hline Mean & & & 0.9 & 3.3 & 1.5 & 1.8 \\
\hline & & & 0.3 & 0.5 & 0.8 & 0.8 \\
\hline \multicolumn{6}{|c|}{ Percent Defect Coverage $<2 \mathrm{~mm}$ KT } & $54 \%$ \\
\hline \multicolumn{7}{|c|}{$\geq 2 \mathrm{~mm}$ Keratinized Tissue } \\
\hline 1 & Mand CS & 23 & 2.0 & 3.0 & 1.0 & 2.0 \\
\hline 2 & Mand CS & 20 & 2.0 & 3.0 & 0.5 & 2.5 \\
\hline 3 & Mand CS & 20 & 2.0 & 3.0 & 0.5 & 2.5 \\
\hline 4 & Mand CS & 29 & 2.0 & 3.0 & 2.0 & 1.0 \\
\hline 5 & Mand CS & 25 & 2.0 & 3.0 & 0.0 & 3.0 \\
\hline 6 & Mand CS & 27 & 2.0 & 3.0 & 0.0 & 3.0 \\
\hline 7 & Mand CS & 21 & 2.5 & 3.0 & 0.5 & 2.5 \\
\hline 8 & Mand CS & 28 & 2.5 & 3.0 & 0.0 & 3.0 \\
\hline 9 & Mand CS & 28 & 2.5 & 4.0 & 1.5 & 2.5 \\
\hline 10 & Mand CS & 21 & 2.5 & 3.0 & 1.0 & 2.0 \\
\hline 11 & Mand NS & 28 & 2.5 & 3.0 & 1.0 & 2.0 \\
\hline 12 & Mand CS & 28 & 3.5 & 3.0 & 0.0 & 3.0 \\
\hline \multicolumn{3}{|l|}{ Mean } & 2.3 & 3.1 & 0.7 & 2.4 \\
\hline & 0.4 & 0.3 & 0.6 & 0.6 \\
\hline \multicolumn{6}{|c|}{ Percent Defect Coverage $\geq 2 \mathrm{~mm} \mathrm{KT}$} & $78 \%$ \\
\hline
\end{tabular}


Table 20

Results of Maxillary Arch Data Pooled from $4 \mathrm{U}$ of L Studies

Mean \pm sd

\begin{tabular}{|c|c|c|c|c|c|c|c|}
\hline \multicolumn{8}{|c|}{ Maxillary Coronally Positioned Flap with Alloderm Sites } \\
\hline Study & Mo & Patient & TC & T\# & Rec0 & Rec12 & Chan \\
\hline Henderson & 12 & & Test & 5 & 4.0 & 1.0 & 3.0 \\
\hline Henderson & 12 & & Cont & 5 & 3.0 & 1.0 & 2.0 \\
\hline Henderson & 12 & & Cont & 5 & 4.0 & 0.0 & 4.0 \\
\hline Mehlbauer & 12 & & Test & 5 & 4.0 & 0.0 & 4.0 \\
\hline Woodyard & 6 & & Test & 5 & 4.0 & 0.0 & 4.0 \\
\hline Woodyard & 6 & & Test & 5 & 3.0 & 0.0 & 3.0 \\
\hline PapaG & 4 & & Cont & 5 & 3.0 & 0.3 & 2.8 \\
\hline Henderson & 12 & & Test & 6 & 11.0 & 1.0 & 10.0 \\
\hline Henderson & 12 & & Cont & 6 & 4.0 & 0.5 & 3.5 \\
\hline Henderson & 12 & & Cont & 6 & 4.0 & 0.0 & 4.0 \\
\hline Henderson & 12 & & Cont & 6 & 4.0 & 0.0 & 4.0 \\
\hline Henderson & 12 & & Cont & 6 & 3.0 & 0.0 & 3.0 \\
\hline Mehlbauer & 12 & & Test & 6 & 4.0 & 0.0 & 4.0 \\
\hline Woodyard & 6 & & Test & 6 & 4.0 & 0.0 & 4.0 \\
\hline Woodyard & 6 & & Test & 6 & 3.0 & 0.0 & 3.0 \\
\hline Woodyard & 6 & & Test & 6 & 3.0 & 0.0 & 3.0 \\
\hline PapaG & 4 & & Cont & 6 & 5.5 & 0.0 & 5.5 \\
\hline PapaG & 4 & & Cont & 6 & 4.0 & 0.0 & 4.0 \\
\hline PapaG & 4 & & Cont & 6 & 3.0 & 0.0 & 3.0 \\
\hline Henderson & 12 & & Test & 7 & 4.0 & 0.0 & 4.0 \\
\hline Henderson & 12 & & Cont & 10 & 3.0 & 0.0 & 3.0 \\
\hline Henderson & 12 & & Test & 11 & 3.0 & 0.5 & 2.5 \\
\hline Henderson & 12 & & Test & 11 & 4.0 & 0.0 & 4.0 \\
\hline Henderson & 12 & & Test & 11 & 3.0 & 0.0 & 3.0 \\
\hline Henderson & 12 & & Test & 11 & 3.0 & 0.0 & 3.0 \\
\hline Henderson & 12 & & Cont & 11 & 6.0 & 0.0 & 6.0 \\
\hline Mehlbauer & 12 & & Test & 11 & 4.0 & 0.0 & 4.0 \\
\hline Mehlbauer & 12 & & Cont & 11 & 3.0 & 0.0 & 3.0 \\
\hline Mehlbauer & 12 & & Cont & 11 & 3.0 & 0.0 & 3.0 \\
\hline Mehlbauer & 12 & & Cont & 11 & 4.0 & 0.5 & 3.5 \\
\hline Mehlbauer & 12 & & Cont & 11 & 3.0 & 0.0 & 3.0 \\
\hline Woodyard & 6 & & Test & 11 & 3.0 & 0.0 & 3.0 \\
\hline Woodyard & 6 & & Test & 11 & 6.0 & 0.0 & 6.0 \\
\hline Woodyard & 6 & & Test & 11 & 3.5 & 0.0 & 3.5 \\
\hline PapaG & 4 & & Cont & 11 & 3.8 & 0.0 & 3.8 \\
\hline PapaG & 4 & & Cont & 11 & 3.0 & 0.0 & 3.0 \\
\hline Henderson & 12 & & Test & 12 & 3.0 & 0.0 & 3.0 \\
\hline Henderson & 12 & & Test & 12 & 4.0 & 0.0 & 4.0 \\
\hline Henderson & 12 & & Cont & 12 & 3.0 & 0.0 & 3.0 \\
\hline Mean & 9.54 & & & & 3.8 & 0.1 & 3.7 \\
\hline sd & 3.39 & & & & 1.4 & 0.3 & 1.3 \\
\hline Count & 39 & & & & 39 & 39 & 39 \\
\hline Percent De & Cove & & & & & & $97 \%$ \\
\hline
\end{tabular}


Table 21

Results of Mandibular Arch Data Pooled from $4 \mathrm{U}$ of L Studies Mean \pm sd

\begin{tabular}{|lccccccc|}
\hline \multicolumn{7}{c|}{ Mandibular Coronally Positioned Flap with Alloderm Sites } \\
\hline Study & Time & Patient & TC & T\# & Rec0 & Rec12 & Chan \\
\hline Mehlbauer & 12 & Test & 20 & 3.5 & 1.0 & 2.5 \\
Mehlbauer & 12 & Cont & 20 & 3.0 & 0.0 & 3.0 \\
PapaG & 4 & Cont & 20 & 3.0 & 0.0 & 3.0 \\
PapaG & 4 & Cont & 20 & 3.0 & 0.0 & 3.0 \\
PapaG & 4 & Cont & 20 & 3.0 & 0.0 & 3.0 \\
PapaG & 4 & Cont & 21 & 3.0 & 0.8 & 2.3 \\
PapaG & 4 & Cont & 21 & 3.5 & 1.0 & 2.5 \\
Mehlbauer & 12 & Test & 22 & 3.0 & 0.0 & 3.0 \\
Mehlbauer & 12 & Cont & 22 & 6.0 & 0.0 & 6.0 \\
Mehlbauer & 12 & Cont & 22 & 3.0 & 0.0 & 3.0 \\
Woodyard & $\mathbf{6}$ & Test & $\mathbf{2 2}$ & 3.0 & 0.5 & 2.5 \\
Woodyard & $\mathbf{6}$ & Test & $\mathbf{2 2}$ & 3.0 & 0.0 & 3.0 \\
Mehlbauer & 12 & Test & 27 & 3.0 & 0.0 & 3.0 \\
Woodyard & $\mathbf{6}$ & Test & 27 & 3.0 & 0.0 & 3.0 \\
PapaG & 4 & Cont & 27 & 3.0 & 0.0 & 3.0 \\
Woodyard & $\mathbf{6}$ & Test & $\mathbf{2 8}$ & 3.0 & 0.0 & 3.0 \\
Mehlbauer & 12 & Test & $\mathbf{2 9}$ & 4.0 & 0.0 & 4.0 \\
\hline Mean & $\mathbf{7 . 8}$ & & & $\mathbf{3 . 3}$ & $\mathbf{0 . 2}$ & $\mathbf{3 . 1}$ \\
sd & $\mathbf{3 . 7}$ & $\mathbf{0 . 8}$ & $\mathbf{0 . 4}$ & $\mathbf{0 . 8}$ \\
Count & $\mathbf{1 7}$ & & & $\mathbf{1 7}$ & $\mathbf{1 7}$ & $\mathbf{1 7}$ \\
Percent Defect Coverage & & & & & & $\mathbf{9 4 \%}$ \\
\hline
\end{tabular}


Table 22

Keratinized tissue gain after acellular dermal matrix root coverage procedures.

Mean \pm sd in $\mathrm{mm}$

\begin{tabular}{|l|c|c|c|c|}
\hline Study & Year & Treatment & Months & KT Gain \\
\hline Henderson & 2001 & CPF/ADM & 12 & 0.8 \\
Henderson & 2001 & CPF/ADM & 12 & 0.8 \\
Woodyard et al. & 2004 & CPF/ADM & 6 & 0.4 \\
Mehlbauer/Greenwell & 2005 & CPF/ADM & 12 & 2.0 \\
Papageorgakopoulos & 2007 & CPF/ADM & 4 & 0.5 \\
Papageorgakopoulos & 2007 & TUN/ADM & 4 & 0.1 \\
Harris & 2000 & CPF/ADM & 3 & 1.2 \\
Aichelmann-Reidy et al. & 2001 & CPF/ADM & 6 & 1.2 \\
Novaes et al. & 2001 & CPF/ADM & 6 & 0.6 \\
Harris & 2002 & CPF/ADM & 19 & 0.4 \\
Paolantonio et al & 2002 & CPF/ADM & 12 & 0.8 \\
Tal et al. & 2002 & CPF/ADM & 12 & 0.9 \\
Harris & 2004 & CPF/ADM & 49 & 0.7 \\
Barros et al. & 2004 & CPF/ADM 1 & 6 & 1.2 \\
Barros et al. & 2004 & CPF/ADM 3 & 6 & 1.0 \\
Cortes et al. & 2004 & CPF/ADM & 6 & 0.7 \\
Santos et al. & 2005 & CPF/ADM & 12 & 1.2 \\
Hirsch et al & 2005 & CPF/ADM & 24 & 2.2 \\
de Queiroz Cortes et al. & 2006 & CPF/ADM & 24 & 0.6 \\
Joly et al. & 2007 & CPF/ADM & 6 & 1.1 \\
Felipe et al. & 2007 & CPF/ADM & 6 & 0.3 \\
Felipe et al. & 2007 & CPF/ADM nr & 6 & 0.1 \\
Papageorgakopoulos & 2008 & CPF/ADM & 4 & 0.8 \\
Papageorgakopoulos & 2008 & TUN/ADM & 4 & 0.6 \\
Andrade et al. & 2008 & Env/ADM & 12 & 0.2 \\
Andrade et al. & 2008 & CPF/ADM & 12 & 0.4 \\
de Souza et al. & 2008 & CPF/ADM & 12 & 1.1 \\
Modarressi et al. & 2009 & TUN/ADM & 12 & -1.1 \\
Shepherd et al. & 2009 & TUN/ADM & 4 & 0.4 \\
Shearer et al. & 2010 & TUN/ADM & 6 & 0.3 \\
Shearer et al. & 2010 & TUN/ADM & 6 & 0.0 \\
\hline Mean \pm sd & & & & $\mathbf{0 . 7}$ \\
\hline
\end{tabular}


Table 23

Creeping attachment after acellular dermal matrix root coverage procedures.

$\underline{\text { Mean } \pm \text { sd in } \mathrm{mm}}$

\begin{tabular}{|l|c|c|c|c|}
\hline Study & Year & Treatment & Months & Creep \\
\hline Henderson et al. & 2001 & CPF/ADM t & 12 & 0.1 \\
Henderson et al. & 2001 & CPF/ADM c & 12 & 0.3 \\
Woodyard et al. & 2004 & CPF/ADM & 6 & 0.0 \\
Papageorgakopoulos et al. & 2007 & CPF/ADM & 4 & 0.0 \\
Papageorgakopoulos et al. & 2007 & TUN/ADM & 4 & -0.2 \\
Novaes et al. & 2001 & CPF/ADM & 6 & 0.1 \\
Harris & 2002 & CPF/ADM & 19 & -0.1 \\
Harris & 2004 & CPF/ADM & 49 & -0.9 \\
Shepherd et al. & 2009 & TUN/ADM & 4 & 0.3 \\
Shearer et al. & 2010 & TUN/ADM & 6 & 0.1 \\
Shearer et al. & 2010 & TUN/ADM & 6 & 0.1 \\
\hline Mean \pm sd & & & & $0.0 \pm 0.3$ \\
\hline
\end{tabular}


Table 24

Summary Table of U of L Coronally Positioned Flap Studies

Percent Defect Coverage Results

\begin{tabular}{|lcccc|}
\hline Study & Pts & Sites & Mo & $\%$ \\
\hline Dodge & 6 & 18 & 2 & 96 \\
Henderson & 10 & 10 & 12 & 95 \\
Henderson & 10 & 10 & 12 & 95 \\
Mehlbauer & 7 & 7 & 12 & 96 \\
Mehlbauer & 7 & 7 & 12 & 98 \\
Woodyard & 12 & 12 & 6 & 99 \\
Papageorgakopoulos & 12 & 12 & 4 & 95 \\
\hline
\end{tabular}


Table 25

Summary Table of U of L Coronally Positioned Tunnel Studies

Percent Defect Coverage Results

\begin{tabular}{|lccccc|}
\hline Study & Proc & Pts & Sites & Mo & $\%$ \\
\hline Papageorgakopoulos & CPT & 12 & 12 & 4 & 78 \\
Shepherd & CPT & 9 & 9 & 4 & 70 \\
Shepherd & PRP & 9 & 9 & 4 & 90 \\
Shearer & Sing & 12 & 12 & 6 & 76 \\
Shearer & Cont & 12 & 12 & 6 & 83 \\
\hline
\end{tabular}




\section{Table 26}

Summary Table of Tunnel Maxillary vs. Mandibular Sites

\section{Percent Defect Coverage Results}

\begin{tabular}{|lccccc|}
\hline Study & Proc & Max n & Max \% & Mand n & Mand \% \\
\hline Papageorgakopoulos & CPT & 6 & 95 & 6 & 62 \\
Shepherd & CPT & 3 & 100 & 6 & 54 \\
Shepherd & PRP & 2 & 100 & 7 & 85 \\
Shearer & Sing & 5 & 91 & 7 & 65 \\
Shearer & Cont & 4 & 100 & 8 & 75 \\
\hline
\end{tabular}


Table 27

Summary Table of Tunnel Maxillary vs. Mandibular Sites from 3 U of L Studies*

Percent Defect Coverage Results

\begin{tabular}{|lcc|}
\hline Arch & $\mathbf{n}$ & \% Coverage \\
\hline Maxillary & 18 & $96 \%$ \\
Mandibular & 27 & $64 \%$ \\
Mandibular PRP & 7 & $85 \%$ \\
\hline
\end{tabular}

* = Papageorgakopoulos, Shepherd, Shearer 


\section{CHAPTER IV}

\section{DISCUSSION}

The primary aim of this randomized, controlled, blinded clinical trial was to assess the clinical outcomes of a coronally positioned tunnel plus an acellular dermal matrix allograft (CPT/ADM) sutured using a single tooth sling technique (Single) when compared to an identical procedure sutured using a continuous sling technique (Continuous). Both the Single and Continuous groups had a significant gain in mean recession defect coverage of $76 \%$ and $83 \%$, respectively $(p<0.05)$. However, there were no statistically significant differences between groups $(p>0.05)$. Complete defect coverage was achieved $33 \%$ of the time ( 4 out of 12 sites) for the Single group, while it occurred $58 \%$ of the time ( 7 out of 12 sites) for the Continuous group.

While there were no statistical differences between groups, the data indicates a slight advantage for the Continuous group. This may be due to the ability to adjust the tension on a continuous sling suture prior to tying. Excessive suture tension can lead to suture pull-out as the tissue swells during initial healing. This can result in flap retraction and fewer sites with complete defect coverage, which did occur in this study for the Single group.

The CPT/ADM is a minimally invasive surgical technique that has significant advantages when compared to other root coverage procedures. No donor site is required 
and there are no visible incisions. Healing is rapid and there is minimal swelling and post-op discomfort, which is a significant benefit for the patient. Thus, this is a preferred technique when it can be used successfully. For Miller Class I and II defects, success should be considered complete defect coverage.

To further determine when the CPT/ADM is most successful, the data from this study was combined with the data from two other CPT/ADM studies performed at this institution (Table 18, 19). The objective of combining the data was to evaluate specific site characteristics to determine whether they influenced the percent defect coverage. This allowed us to focus on the effect of the dental arch and the keratinized tissue width.

The combined data yielded 18 maxillary sites and 26 mandibular sites available for analysis. The percent defect coverage was $96 \%$ for the maxillary sites and $64 \%$ for the mandibular sites. Thus, for maxillary sites, complete defect coverage was highly predictable and occurred $78 \%$ of the time (14 of 18 sites) compared to $23 \%$ of the time (6 of 26 sites) for mandibular sites. In this study, 95\% defect coverage was achieved in maxillary sites vs. $70 \%$ in mandibular sites. This raised the question of why there was such a profound difference between arches in terms of percent defect coverage. Width of keratinized tissue was considered a potential factor in the difference between dental arches.

The arch data was stratified into groups with $<2 \mathrm{~mm}$ of keratinized tissue vs. $\geq 2$ mm. This yielded 8 maxillary sites with $<2 \mathrm{~mm}$ vs. 10 sites with $\geq 2 \mathrm{~mm}$ and 15 mandibular sites with $<2 \mathrm{~mm}$ and 12 sites with $\geq 2 \mathrm{~mm}$ of keratinized tissue. For mandibular sites, keratinized tissue width had a clinically significant effect and mean defect coverage was $54 \%$ for sites $<2 \mathrm{~mm}$ vs. $78 \%$ for sites $\geq 2 \mathrm{~mm}$. For the maxillary 
sites, the result was good irrespective of keratinized tissue width. Sites with $<2 \mathrm{~mm}$ had $98 \%$ defect coverage while sites $\geq 2 \mathrm{~mm}$ had $94 \%$.

In a previous report, the CPT/ADM was utilized with and without the use of platelet rich plasma (PRP). Defect coverage of $90 \%$ was achieved in the PRP group (9 sites) while $70 \%$ was obtained in the group without PRP (9 sites). Sub-analysis of the mandibular sites revealed $85 \%$ defect coverage in the PRP group ( 7 sites) vs. $54 \%$ in the group without PRP (6 sites). All of the combined data and sub-analyses previously discussed were not subjected to statistical analysis due to the unequal number of sites. The purpose was to determine if there were indications of a clinically significant difference. This data was regarded as a guide to the need for future studies and as an indication of where the CPT/ADM procedure performed best.

The CPT/ADM procedure works well and predictably in the maxilla. In the mandible, the procedure is less predictable although data indicated $\geq 2 \mathrm{~mm}$ of keratinized tissue and the use of PRP may increase the predictability. Another means of root coverage using acellular dermal matrix is to use a coronally positioned flap (CPF/ADM). Combining data from 4 previous studies at this institution yielded 56 sites treated with a CPF/ADM and 96\% defect coverage was achieved. Analysis of this data by arch revealed 39 maxillary and 17 mandibular sites. Defect coverage of $97 \%$ for the maxillary and $94 \%$ for mandibular sites was obtained. Thus, the CPF/ADM appears to have similar predictability in both maxillary and mandibular sites. Therefore, the CPF/ADM may be indicated in mandibular sites where there is minimal keratinized tissue or when PRP is not being used. The CPT/ADM, however, should be considered the procedure of choice 
when proper conditions exist due to the minimally invasive nature of the procedure and the negligible post-operative discomfort to the patient.

From 2 to 6 months both the Single and Continuous groups showed a slight increase in mean recession of $0.1 \mathrm{~mm}$ (Table 10). This indicates a tendency for a minimal amount of marginal tissue retraction after 2 months of healing. This is consistent with the findings in two previous studies of the CPT/ADM at this institution (Papageorgakopoulos 2008, Shepherd 2009). The amount of retraction is minimal and appears to be clinically insignificant.

The width of keratinized tissue increased from time 0 to 6 months for the Single group by $0.3 \mathrm{~mm}$ but remained unchanged for the Continuous group. Papageorgakopoulos et al. (2008) reported an increase of $0.8 \mathrm{~mm}$ using the CPT/ADM procedure while Shepherd et al. (2009) reported an increase of $0.4 \mathrm{~mm}$. In general, the use of the CPT/ADM seems to have minimal positive effect on the keratinized tissue width.

Modarressi and Wang (2009) evaluated the results of a CPT/ADM procedure in multiple sites in 5 patients over a one-year period. They reported defect coverage of $61 \%$ and loss of $1.1 \mathrm{~mm}$ of keratinized tissue in maxillary non-molar teeth. An evaluation of post-op discomfort showed that patients had minimal discomfort and healed uneventfully. This confirms the findings in this study that the CPT/ADM procedure is an excellent procedure for root coverage and provides a significant benefit for the patient, especially in terms of minimizing post-operative discomfort. 


\section{CHAPTER V CONCLUSIONS}

Within the limits of this study design it may be concluded that:

1) Both the coronally positioned tunnel with acellular dermal matrix (CPT/ADM) with the single tooth sling suture (Single) and the CPT/ADM with the continuous sling suture (Continuous) achieved a significant amount of defect coverage, 76 vs. $83 \%$, respectively, although there were no significant differences between groups.

2) The predictability of achieving complete defect coverage was greater for the Continuous group than the Single group, 58 vs. $33 \%$, respectively.

3) The CPT/ADM was much more effective and predictable for defect coverage in the maxilla than the mandible, 95 vs. $70 \%$, respectively. 


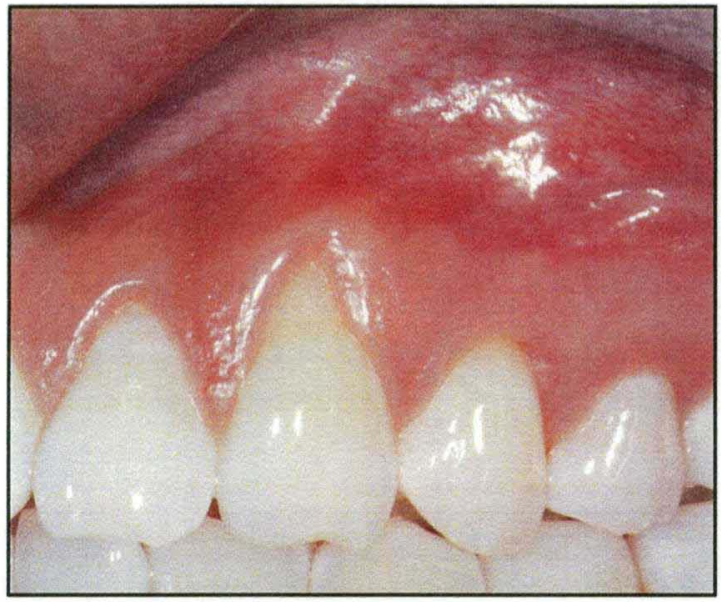

Figure 1a. Pre-op \#11

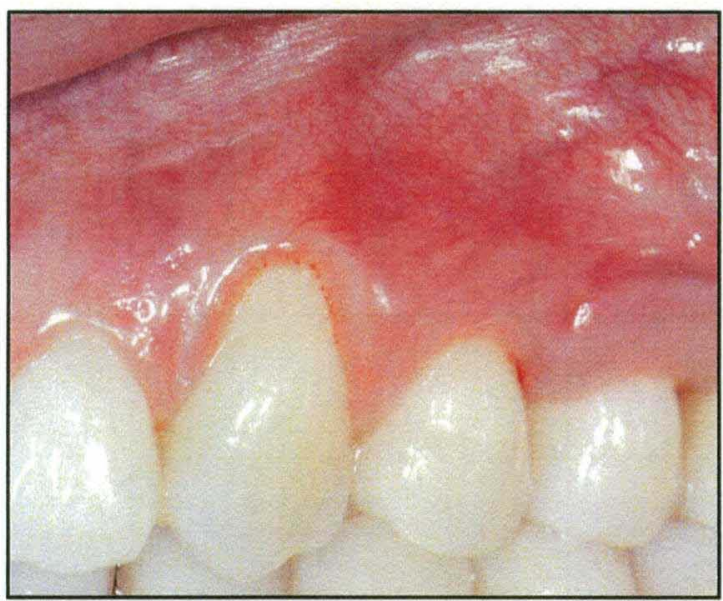

Figure 2a. Pre-op \#11

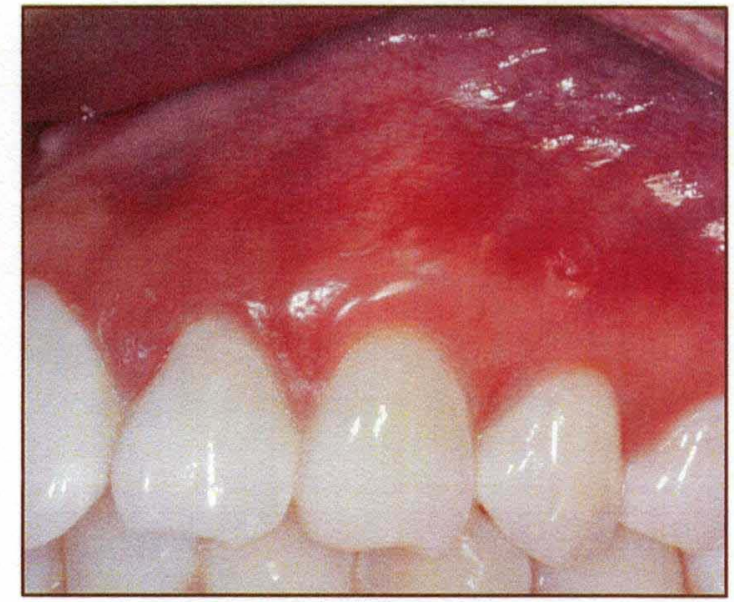

Figure 1b. 6-month post-op 11

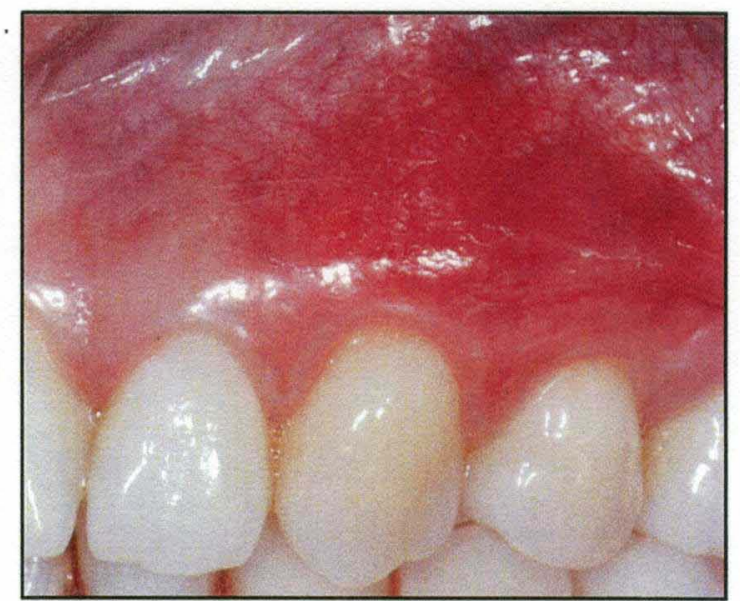

Figure 2b. 6-month post-op \#11

\section{Single Tooth Sling Group}




\section{dnoxற ฮิu!IS snonu!̣uoว}
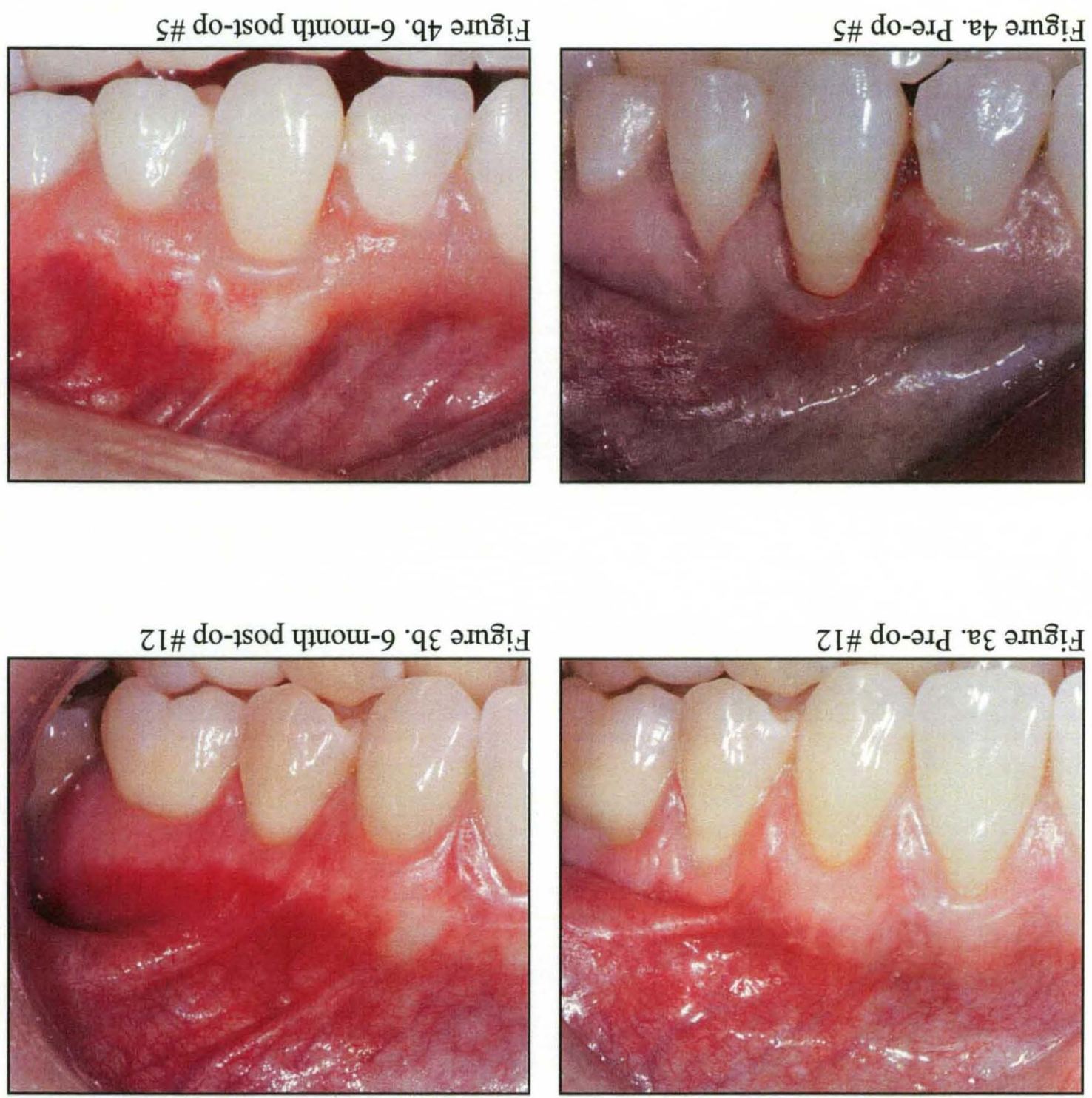


\section{REFERENCES}

Abolfazli N, Saleh-Saber F, Eskandari A, Lafzi A. A comparative study of the long term results of root coverage with connective tissue graft or enamel matrix protein: 24-month results. J West Soc Periodontol 2009;14(6):304-9.

Aichelmann-Reidy ME, Yukna RA, Evans GH, Nasr HF, Mayer ET. Clinical evaluation of acellular allograft dermis for the treatment of human gingival recession. J Periodontol 2001;72:998-1005.

Al-Zahrani MS, Bissada NF, Ficara AJ, Cole B. Effect of connective tissue graft orientation on root coverage and gingival augmentation. Int $\mathrm{J}$ Periodontics Restorative Dent 2004;24(1):65-69.

Albandar JM, Kingman A. Gingival recession, gingival bleeding and dental calculus in adults 30 years of age and older in the United States, 1988-1994. J Periodontol 1999;70:30-43.

Allen AL. Use of the supraperiosteal envelope in soft tissue grafting for root coverage. I. Rationale and technique. Int J Periodontics Restorative Dent 1994a;14(3):216-227.

Allen AL. Use of the supraperiosteal envelope in soft tissue grafting for root coverage. II. Clinical results. Int J Periodontics Restorative Dent 1994b;14(4):302-315.

Allen EP, Miller PD Jr. Coronal positioning of existing gingiva: short term results in the treatment of shallow marginal tissue recession. J Periodontol 1989;60:316-319. 
Amarante ES, Leknes KN, Skavland J, Lie T. Coronally positioned flap procedures with or without a bioabsorbable membrane in the treatment of human gingival recession. $\mathrm{J}$ Periodontol 2000;71:989-998.

Andia DC, Martins AG, Casati MZ, Sallum EA, Nociti FH. Root coverage outcome may be affected by heavy smoking: a 2-year follow-up study. J Periodontol 2008;79(4):64753.

Andrade PF, Felipe ME, Novaes Jr AB, Souza SL, Taba Jr M, Palioto DB, Grisi MF. Comparison between two surgical techniques for root coverage with an acellular dermal matrix graft. J Clin Periodontol 2008;35:263-269.

Aranda JJ, Sanz M, Lazaro PJ. Surgical treatment of wide and isolated gingival recession. Guided tissue regeneration (GTR) versus supraperiosteal envelope technique: A randomized clinical study. (Abstract 115). J Dent Res 1996;75(Suppl):32.

Ariaudo AA. Problems in treating a denuded labial root surface of a lower incisor. J Periodontol 1966;37:274-278.

Armitage GC. Development of a classification system for periodontal diseases and conditions. Ann Periodontol 1999;4(1):1-6.

Aroca S, Keglevich T, Barbieri B, Gera I, Etienne D. Clinical evaluation of a modified coronally advanced flap alone or in combination with a platelet-rich fibrin membrane for the treatment of adjacent multiple gingival recessions: a 6-month study. J Periodontol 2009;80(2):244-52.

Baker D, Seymour G. The possible pathogenesis of gingival recession. J Clin Periodontol 1976;3:208-219. 
Baldi C, Pini Prato G, Pagliaro U, Nieri M, Saletta D, Muzzi L, Cortellini P. Coronally advanced flap procedure for root coverage. Is flap thickness a relevant predictor to achieve root coverage? A 19-case series. J Periodontol 1999;70:1077-1084.

Banihashemrad A, Aghassizadeh E, Radvar M. Treatment of gingival recessions by guided tissue regeneration and coronally advanced flap. N Y State Dent J 2009;75(1):548.

Barros RR, Novaes AB, Grisi MF, Souza SL, Taba M, Palioto DB. A 6-month comparative clinical study of a conventional and a new surgical approach for root coverage with acellular dermal matrix. J Periodontol 2004;75(10):1350-1356.

Bernimoulin JP, Luscher B, Mühlemann HR. Coronally repositioned periodontal flap. Clinical evaluation after one year. J Clin Periodontol 1975;2:1-13.

Bittencourt S, Ribeiro Edel P, Sallum EA, Sallum AW, Nociti FH, Casati MZ. Semilunar coronally positioned flap or subepithelial connective tissue graft for the treatment of gingival recession: a 30-month follow-up study. J Periodontol 2009;80(7):1076-82.

Bittencourt S, Ribeiro EDP, Sallum EA, Sallum AW, Nociti Jr FH, Casati MZ. Comparative 6-month clinical study of a semilunar coronally positioned flap and subepithelial connective tissue graft for the treatment of gingival recession. $J$ Periodontol 2006;77(2):174-181.

Bjorn H. Free transplantation of gingiva propria. Swedish Dent J 1963;22:684-689.

Blanes RJ, Allen EP. The bilateral pedicle flap-tunnel technique: a new approach to cover connective tissue grafts. Int J Periodontics Restorative Dent 1999;19(5):471-479. 
Borghetti A, Glise J, Monnet-Corti V, Dejou J. Comparative clinical study of a bioabsorable membrane and subepithelial connective tissue graft in the treatment of human gingival recession. J Periodontol 1999;70:123-130.

Borghetti A, Louise F. Controlled clinical evaluation of the subpedicle connective tissue graft for the coverage of gingival recession. J Periodontol 1994;65:1107-1112.

Bouchard P, Etienne D, Ouhayoun JP, Nilveus R. Subepithelial connective tissue grafts in the treatment of gingival recessions. A comparative study of 2 procedures. $\mathrm{J}$ Periodontol 1994;65:929-936.

Bouchard P, Nilveus R, Etienne D. Clinical evaluation of tetracycline $\mathrm{HCl}$ conditioning in the treatment of gingival recession. A comparative study. J Periodontol 1997;68:262269.

Bruno JF. Connective tissue graft technique assuring wide root coverage. Int $\mathbf{J}$ Periodontics Restorative Dent 1994;14(2):126-137.

Bruno JF, Bowers GM. Histology of human biopsy section following the placement of a subepithelial connective tissue graft. Int J Periodontics Restorative Dent 2000;20(3):225231.

Burkhardt R, Lang NP. Coverage of localized gingival recessions: Comparison of microand macrosurgical techniques. J Clin Periodontol 2005;32(3):287-293.

Byun HY, Oh TJ, Abuhussein HM, Yamashita J, Soehren SE, Wang HL. Significance of the epithelial collar on the subepithelial connective tissue graft. J Periodontol 2009;80(6):924-32. 
Caffesse RG, De LaRosa M, Garza M, Munne-Travers A, Mondragon JG, Weltman R. Citric acid demineralization and subepithelial connective tissue grafts. J Periodontol 2000;71:568-572.

Cardaropoli D, Cardaropoli G. Healing of gingival recessions using a collagen membrane with a hemineralized xenograft: a randomized controlled clinical trial. Int J Periodontics Restorative Dent 2009;29(1):59-67.

Carnio J, Camargo PM, Kenney EB. Root resorption associated with a subepithelial connective tissue graft for root coverage: clinical and histologic report of a case. Int $J$ Periodontics Restorative Dent 2003;23(4):391-398.

Carvalho PF, da Silva RC, Curry PR, Joly JC. Modified coronally advanced flap associated with a subepithelial connective tissue graft for the treatment of adjacent multiple gingival recessions. J Periodontol 2006;77(11):1901-1906.

Castellanos A, de la Rosa R M, de la Garza M, Caffesse RG. Enamel matrix derivative and coronal flaps to cover marginal tissue recessions. J Periodontol 2006; 77(1):7-14.

Cetiner D, Bodur A, Uraz A. Expanded mesh connective tissue graft for the treatment of multiple gingival recessions. J Periodontol 2004;75(8):1167-1172.

Cetiner D, Parlar A, Balos K, Alpar R. Comparative clinical study of connective tissue graft and two types of bioabsorbable barriers in the treatment of localized gingival recessions. J Periodontol 2003;74(8):1196-1205.

Chambrone LA, Chambrone L. Subepithelial connective tissue grafts in the treatment of multiple recession-type defects. J Periodontol 2006;77(5):909-916.

Cheung WS, Griffin TJ. A comparative study of root coverage with connective tissue and platelet concentrate grafts: 8-month results. J Periodontol 2004;75(12): 1678-1687. 
Ciancio SG, Hazen SP, Cunat JJ. Periodontal observations in twins. J Periodont Res 1969;4(1):42-45.

Cohen DW, Ross SE. The double papillae repositioned flap in periodontal therapy. J Periodontol 1968;39:65-70.

Cordioli G, Mortarino C, Chierico A, Grusovin MG, Majzoub Z. Comparison of 2 techniques of subepithelial connective tissue graft in the treatment of gingival recessions. J Periodontol 2001;72:1470-1476.

Cortellini P, Tonetti M, Baldi C, Francetti L, Rasperini G, Rotundo R, Nieri M, Franceschi D, Labriola A, Prato GP. Does placement of a connective tissue graft improve the outcomes of coronally advanced flap for coverage of single gingival recessions in upper anterior teeth? A multi-centre, randomized, double-blind, clinical trial. J Clin Periodontol 2009;36(1):68-79.

Cortes A, Martins AG, Nociti FH, Sallum AW, Casati MZ, Sallum EA. Coronally positioned flap with or without acellular dermal matrix graft in the treatment of class I gingival recessions: A randomized controlled clinical study. J Periodontol 2004;75(8):1137-1144.

Cummings LC, Kaldahl WB, Allen EP. Histologic evaluation of autogenous connective tissue and acellular dermal matrix grafts in humans. J Periodontol 2005;76(2):178-186.

da Silva RC, Joly JC, de Lima AF, Tatakis DN. Root coverage using the coronally positioned flap with or without a subepithelial connective tissue graft. J Periodontol 2004;75:413-419. 
'SS I I-8D I I:(L)LL:900Z

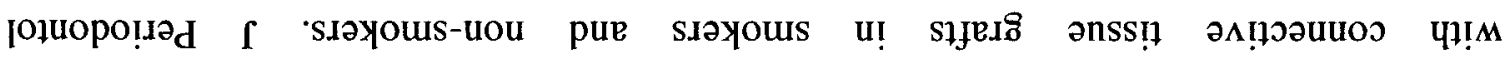

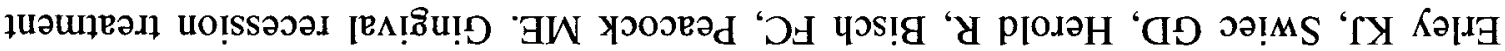

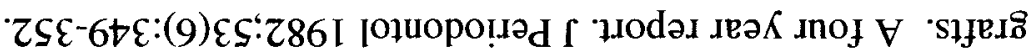

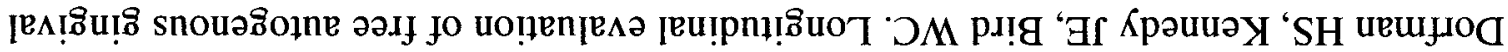

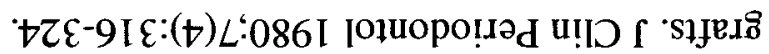

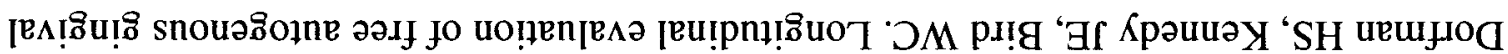

969-I69:( I I $)$ tt:EL6I

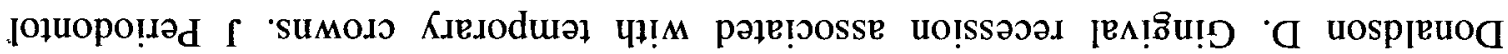

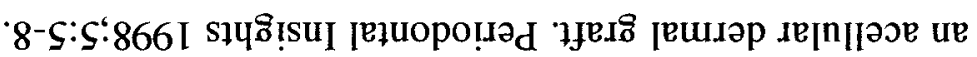

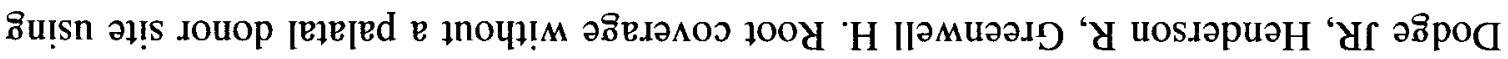

$\mathcal{L}-\mathrm{I}:(\mathcal{E}) t 0 \mathrm{I}: \angle 00 Z$

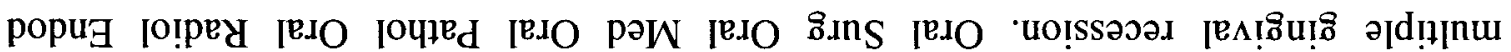

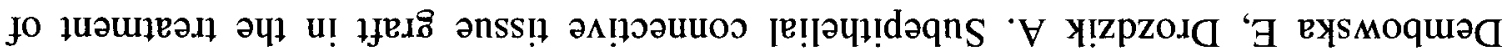

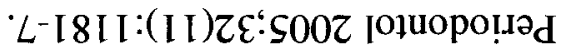

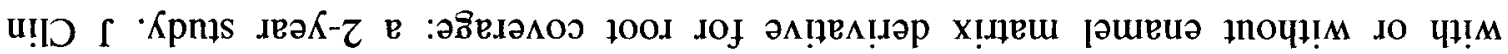

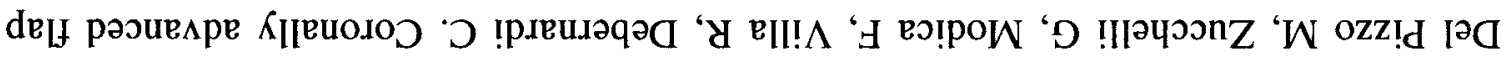

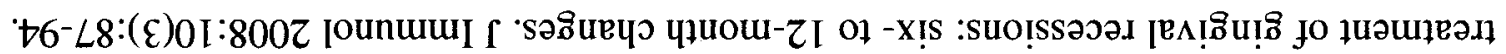

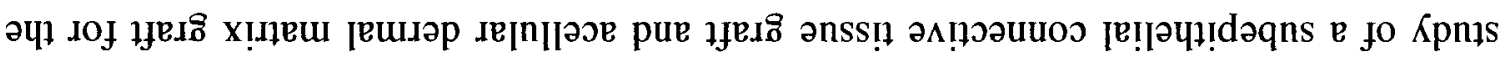

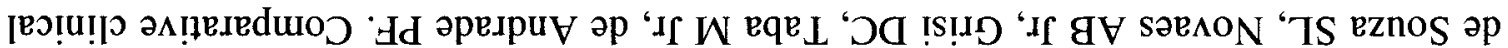

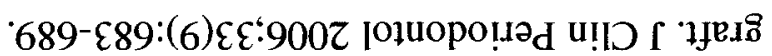

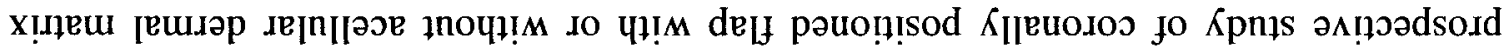

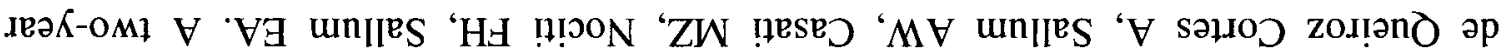


Ewen S. Frena: their roles in periodontics. N Y State Dent J 1968;34(10):626-630.

Felipe ME, Andrade PF, Grisi MF, Souza SL, Taba M, Palioto DB, Novaes AB. Comparison of two surgical procedures for use of the acellular dermal matrix graft in the treatment of gingival recessions: A randomized controlled clinical study. J Periodontol 2007;78(7):1209-1217.

Francetti L, Del Fabbro M, Testori T, Weinstein RL. Periodontal microsurgery: Report of 16 cases consecutively treated by the free rotated papilla autograft technique combined with the coronally advanced flap. Int J Periodontics Restorative Dent 2004;24(3):272279.

Freedman AL, Salkin LM, Stein MD, Green K. A 10 year longitudinal study of untreated mucogingival defects. J Periodontol 1992;63(2):71-72.

Friedman N. Mucogingival surgery. Tex Dent J 1957;75:358-362.

Gartrell JR, Matthews D. Gingival recession. The condition, process, and treatment. Dent Clin North Am 1976;20(1):199-213.

Georges P, Nisand D, Etienne D, Mora F. Efficacy of the supraperiosteal envelope technique: a preliminary comparative clinical study. Int J Periodontics Restorative Dent 2009;29(2):201-11.

Goldman H, Schluger S, Fox L, Cohen D. Periodontal therapy. C.V.Mosby, St. Louis $1964 ; 3$ rd ed 560.

Goldstein M, Boyan BD, Cochran DL, Schwartz Z. Human histology of new attachment after root coverage using subepithelial connective tissue graft. J Clin Periodontol 2001;28(7):657-662. 
Goldstein M, Nasatzky E, Goultschin J, Boyan BD, Schwartz Z. Coverage of previously carious roots is as predictable a procedure as coverage of intact roots. $\mathrm{J}$ Periodontol 2002;73:1419-1426.

Gorman WJ. Prevalence and etiology of gingival recession. J Periodontol 1967;38:316322.

Gottlow J, Nyman S, Karring T, Lindhe J. Treatment of localized gingival recessions with coronally displaced flaps and citric acid. An experimental study in the dog. J Clin Periodontol 1986;13:57-63.

Gottsegen R. Frenum position on vestibule depth in relation to gingival health. Oral Surg 1954;7(10):1069-1078.

Green L, Levin M. Treatment of an unusual case of incipient gingival recession exhibiting a familial tendency: A case report. J Periodontol 1973;44(8):519-524.

Greenwell H, Fiorellini J, Giannobile W, Offenbacher S, Salkin L, Townsend C, Sheridan P, Genco R; Research, Science and Therapy Committee Oral reconstructive and corrective considerations in periodontal therapy. J Periodontol 2005;76(9):1588-1600.

Grupe HE, Warren RF Jr. Repair of gingival defects by a sliding flap operation. J Periodontol 1956;27:92-95.

Gunay H, Dogan S, Geurtsen W. Harvesting technique using a mucotome and modified surgical procedure for root coverage with enamel matrix derivatives with and without a connective tissue graft. Int J Periodontics Restorative Dent 2008;28(5):497-507. 
Hagewald S, Spahr A, Rompola E, Haller B, Heijl L, Bernimoulin JP. Comparative study of Emdogain and coronally advanced flap technique in the treatment of human gingival recessions. A prospective controlled clinical study. J Clin Periodontol 2002;29:35-41.

Haghighati F, Mousavi M, Moslemi N, Kebria MM, Golestan B. A comparative study of two root-coverage techniques with regard to interdental papilla dimension as a prognostic factor. Int J Periodontics Restorative Dent 2009;29(2):179-89.

Han JS, John V, Blanchard SB, Kowolik MJ, Eckert GJ. Changes in gingival dimensions following connective tissue grafts for root coverage: comparison of two procedures. $J$ Periodontol 2008;79(8):1346-54.

Hangorsky U, Bissada NF. Clinical assessment of free gingival graft effectiveness on the maintenance of periodontal health. J Periodontol 1980;51(5):274-278.

Harris RJ. The connective tissue and partial thickness double pedicle graft: a predictable method of obtaining root coverage. J Periodontol 1992;63:477-486.

Harris RJ. The connective tissue with partial thickness double pedicle graft: the results of 100 consecutively-treated defects. J Periodontol 1994;65:448-461.

Harris RJ. A comparative study of root coverage obtained with guided tissue regeneration utilizing a bioabsorbable membrane versus the connective tissue with partial-thickness double pedicle graft. J Periodontol 1997;68:779-790.

Harris RJ. A comparison of 2 root coverage techniques: guided tissue regeneration with a bioabsorbable matrix style membrane versus a connective tissue graft combined with a coronally positioned pedicle graft without vertical incisions. Results of a series of consecutive cases. J Periodontol 1998;69:1426-1434. 
Harris RJ. Root coverage with a connective tissue with partial thickness double pedicle graft and an acellular dermal matrix graft: A clinical and histological evaluation of a case report. J Periodontol 1998;69:1305-1311.

Harris RJ. Human histologic evaluation of root coverage obtained with a connective tissue with partial thickness double pedicle graft. A case report. J Periodontol 1999;70:813-821.

Harris RJ. Successful root coverage: a human histologic evaluation of a case. Int J Periodontics Restorative Dent 1999;19(5):439-448.

Harris RJ. A comparative study of root coverage obtained with an acellular dermal matrix versus a connective tissue graft: Results of 107 recession defects in 50 consecutively treated patients. Int J Periodontics Restorative Dent 2000;20(1):51-59.

Harris RJ. Gingival augmentation with an acellular dermal matrix: human histologic evaluation of a case - placement of the graft on bone. Int J Periodontics Restorative Dent 2001;21(1):69-75.

Harris RJ. Connective tissue grafts combined with either double pedicle grafts or coronally positioned pedicle grafts: results of 266 consecutively treated defects in 200 patients. Int J Periodontics Restorative Dent 2002;22(5):463-471.

Harris RJ. Root coverage with connective tissue grafts: an evaluation of short- and longterm results. J Periodontol 2002;73:1054-1059.

Harris RJ. Acellular dermal matrix used for root coverage: 18-month follow-up observation. Int J Periodontics Restorative Dent 2002;22(2):156-163.

Harris RJ. Root coverage in molar recession: report of 50 consecutive cases treated with subepithelial connective tissue grafts. J Periodontol 2003;74:703-708. 
Harris RJ. A short-term and long-term comparison of root coverage with an acellular dermal matrix and a subepithelial graft. J Periodontol 2004;75(5):734-743.

Harris RJ, Harris LE, Harris CR, Harris AJ. Evaluation of root coverage with two connective tissue grafts obtained from the same location. Int J Periodontics Restorative Dent 2007;27(4):333-9.

Harris RJ, Miller LH, Harris CR, Miller RJ. A comparison of three techniques to obtain root coverage on mandibular incisors. J Periodontol 2005;76(10):1758-1767.

Henderson RD, Greenwell H, Drisko C, Regennitter FJ, Lamb JW, Mehlbauer MJ, Goldsmith LJ, Rebitski G. Predictable multiple site root coverage using an acellular dermal matrix allograft. J Periodontol 2001;72;571-582.

Hirsch A, Goldstein M, Goultschin J, Boyan BD, Schwartz Z. A 2-year follow-up of root coverage usig subpedicle acellular dermal matrix allografts and subepithelial connective tissue autografts. J Periodontol 2005;76(8):1323-1328.

Hirschfeld I. Toothbrush trauma recession. A clinical study. J Dent Res 1931;11(1):6163.

Huang LH, Neiva RE, Wang HL. Factors affecting the outcomes of coronally advanced flap root coverage procedure. J Periodontol 2005;76(10):1729-1734.

Huang LH, Neiva REF, Soehren SE, Giannobile WV, Wang HL. The effect of plateletrich plasma on the coronally advanced flap root coverage procedure: A pilot human trial. J Periodontol 2005;76(10):1768-1777.

Jahnke PV, Sandifer JB, Gher ME, Gray JL, Richardson AC. Thick free gingival and connective tissue autografts for root coverage. J Periodontol 1993;64:315-322. 
Jankovic SM, Zoran AM, Lekovic MV, Bozidar DS, Kenney BE. The use of platelet-rich plasma in combinatin with connective tissue grafts following tratment of gingival recessions. Periodontal Practice Today 2007;4:63-71.

Jepsen K, Heinz B, Halben JH, Jepsen S. Treatment of gingival recession with titanium reinforced barrier membranes versus connective tissue grafts. J Periodontol 1998;69:383391.

Joly JC, Carvalho AM, da Silva RC, Ciotti DL, Cury PR. Root coverage in isolated gingival recessions using autograft versus allograft: A pilot study. J Periodontol 2007;78(6):1017-1022.

Joshipura KJ, Kent RL, DePaola. Gingival recession: intra-oral distribution and associated factors. J Periodontol 1994;65(9):864-871.

Kassab MM, Cohen RE, Andreana S, Dentino AR. The effect of EDTA in attachment gain and root coverage. Compend Contin Educ Dent 2006;27(6):353-60.

Kennedy JE, Bird WC, Palcanis KG, Dorfman HS. A longitudinal evaluation of varying widths of attached gingiva. J Clin Periodontol 1985;12:667-675.

Lang NP, Loe $\mathrm{H}$. The relationship between the width of keratinized gingiva and gingival health. J Periodontol 1972;43(10)623-627.

Langer B, Calagna L. The subepithelial connective tissue graft. J Prosthet Dent 1980;44:363-367.

Langer B, Calagna LJ. The subepithelial connective tissue graft. A new approach to the enhancement of anterior cosmetics. Int J Periodontics Restorative Dent 1982;2(2):22-33. 
Laster L, Laudenbach K, Stoller N. An evaluation of clinical tooth mobility measurements. J Periodontol 1975;46(10):603-607.

Lee YM, Kim JY, Seol YJ, Lee YK, Ku Y, Rhyu IC, Han SB, Choi SM, Chung CP. A 3year longitudinal evaluation of subpedicle free connective tissue graft for gingival recession coverage. J Periodontol 2002;73:1412-1418.

Leis HJ, Leis SN. The papilla rotation flap. J Periodontol 1978;49:400-402.

Leknes KN, Amarante ES, Price DE, Boe OE, Skavland RJ, Lie T. Coronally positioned flap procedures with or without a biodegradable membrane in the treatment of human gingival recession. A 6-year follow-up study. J Clin Periodontol 2005;32(5):518-529.

Levine RA. Covering denuded maxillary root surfaces with the subepithelial connective tissue graft. Compend Contin Educ Dent 1991;12:568,570,572 passim.

Lins LH, de Lima AF, Sallum AW. Root coverage: Comparison of coronally positioned flap with and without titanium-reinforced barrier membrane. J Periodontol 2003;74:168174.

Lobene RR, Weatherford T, Ross NM, Lamm RA, Menaker L. A modified gingival index for use in clinical trials. Clin Prev Dent 1986;8(1):3-6.

Loe $H$. The gingival index, the plaque index and the retention index systems. $J$ Periodontol 1967;38(Suppl):610-617.

Loe H, Anerud A, Boysen H. The natural history of periodontal disease in man: prevalence, severity, and extent of gingival recession. J Periodontol 1992;63:489-495.

Löst C. Depth of alveolar bone dehiscences in relation to gingival recessions. J Clin Periodontol 1984;11:583-589. 
Majzoub Z, Landi L, Grusovin MG, Cordioli G. Histology of connective tissue graft. A case report. J Periodontol 2001;72:1607-1615.

Martins AG, Andia DC, Sallum AW, Sallum EA, Casati MZ, Nociti FH Jr. Smoking may affect root coverage outcome: A prospective clinical study in humans. J Periodontol 2004;75:586-591.

Matter J. Creeping attachment of free gingival grafts. A five-year follow-up study. J Periodontol 1980;51:681-685.

McGuire MK, Nunn M. Evaluation of human recession defects treated with coronally advanced flaps and either enamel matrix derivative or connective tissue. Part 1: Comparison of clinical parameters. J Periodontol 2003;74:1110-1125.

Mehlbauer MJ, Greenwell H. Complete root coverage at multiple sites using an acellular dermal matrix allograft. Compend Contin Educ Dent 2005;26(10):727-733.

Milano F. A combined flap for root coverage. Int J Periodontics Restorative Dent 1998;18(6):544-551.

Miller AJ, Brunelle JA, Carlos JP, Brown LJ, Loe H. Oral health of United States adults. The national survey of oral health in U.S. employed adults and seniors: 1985-1986, national finding. US Department of Health and Human Services. NIH Publication 87 2868. NIH Publication 87-2868 1987;3-11,69-98.

Miller PD Jr. Root coverage using a free soft tissue autograft following citric acid application. I. Technique. Int J Periodontics Restorative Dent 1982;2(1):65-70. 
Miller PD Jr. Root coverage using a free soft tissue autograft following citric acid application. II. Treatment of the carious root. Int $\mathbf{J}$ Periodontics Restorative Dent 1983;3(5):38-51.

Miller PD Jr. A classification of marginal tissue recession. Int J Periodontics Restorative Dent 1985;5(2):8-13.

Miller PD Jr. Root coverage using the free soft tissue autograft following citric acid application. III. A successful and predictable procedure in areas of deep-wide recession. Int J Periodontics Restorative Dent 1985;5(2):14-37.

Miyasato M, Crigger M, Egelberg J. Gingival condition in areas of minimal and appreciable width of keratinized gingiva. J Clin Periodontol 1977;4(3)200-209.

Mlinek A, Smukler H, Buchner A. The use of free gingival grafts for the coverage of denuded roots. J Periodontol 1973;44:248-254.

Modaressi M, Wang HL. Tunneling procedure for root coverage using acellular dermal matrix: a case series. Int J Periodontics Restorative Dent 2009;29(4):395-403.

Modica F, DelPizzo M, Roccuzzo M, Romagnoli R. Coronally advanced flap for the treatment of buccal gingival recessions with and without enamel matrix derivative. A split-mouth study. J Periodontol 2000;71:1693-1698.

Moses O, Artzi Z, Sculean A, Tal H, Kozlovsky A, Romanos GE, Nemcovsky CE. Comparative study of two root coverage procedures: A 24-month follow-up multicenter study. J Periodontol 2006;77(2):195-202.

Müller HP, Eger T, Schorb A. Gingival dimensions after root coverage with free connective tissue grafts. J Clin Periodontol 1998;25:424-430. 
Muller HP, Stahl M, Eger T. Root coverage employing an envelope technique or guided tissue regeneration with a bioabsorbable membrane. J Periodontol 1999;70:743-751.

Müller HP, Stahl M, Eger T. Failure of root coverage of shallow gingival recessions employing GTR and a bioresorbable membrane. Int J Periodontics Restorative Dent $2001 ; 21(2): 171-181$.

Nabers JM. Free gingival grafts. Periodontics 1966;4(5)243-245.

Nelson SW. The subpedicle connective tissue graft. A bilaminar reconstructive procedure for the coverage of denuded root surfaces. J Periodontol 1987;58:95-102.

Nemcovsky CE, Artzi Z, Tal H, Kozlovsky A, Moses O. A multicenter comparative study of two root coverage procedures: coronally advanced flap with addition of enamel matrix proteins and subpedicle connective tissue graft. J Periodontol 2004;75:600-607.

Novaes AB, Grisi DC, Molina GO, Souza SL, Taba M, Grisi MF. Comparative 6-month clinical study of a subepithelial connective tissue graft and acellular dermal matrix graft for the treatment of gingival recession. J Periodontol 2001;72:1477-1484.

O'Leary TJ, Drake RB, Crump PP, Allen MF. The incidence of recession in young males: A further study. J Periodontol 1971;42:264-267.

Paolantonio M. Treatment of gingival recessions by combined periodontal regenerative technique, guided tissue regeneration and subpedicle connective tissue graft. A comparative clinical study. J Periodontol 2002;73:53-62.

Paolantonio M, di Murro C, Cattabriga A, Cattabriga M. Subpedicle connective tissue graft versus free gingival graft in the coverage of exposed root surfaces. A 5-year clinical study. J Clin Periodontol 1997;24:51-56. 
Paolantonio M, Dolci M, Esposito P, D'Archivio D, Lisanti L, Di Luccio A, Perinetti G. Subpedicle acellular dermal matrix graft and autogenous connective tissue graft in the treatment of gingival recessions: a comparative 1-year clinical study. J Periodontol 2002;73:1299-1307.

Papageorgakopoulos G, Greenwell H, Hill M, Vidal R, Scheetz JP. Root coverage using an acellular dermal matrix and comparing a coronally positioned tunnel to a coronally positioned flap approach. J Periodontol 2008;79(6):1022-1030.

Pattison GL. Self-inflicted gingival injuries: Literature review and case report. J Periodontol 1983;54(5):299-304.

Patur B. The rotation flap for covering denuded root surfaces - a closed wound technique. J Periodontol 1977;48:41-44.

Pennel B, Higgason J, Towner J, King K, Fritz B, Sadler J. Oblique rotated flap. J Periodontol 1965;36:305-309.

Pilloni A, Paolantonio M, Camargo PM. Root coverage with a coronally positioned flap used in combination with enamel matrix derivative: 18-month clinical evaluation. J Periodontol 2006;77(12):2031-2039.

Pini Prato G, Baldi C, Pagliaro U, Nieri M, Saletta D, Rotundo R, Cortellini P. Coronally advanced flap procedure for root coverage. Treatment of root surface: root planing vs. polishing. J Periodontol 1999;70:1064-1076.

Pini Prato G, Pagliaro U, Baldi C, Nieri M, Saletta D, Cairo F, Cortellini P. Coronally advanced flap procedure for root coverage. Flap with tension versus flap without tension: a randomized controlled clinical study. J Periodontol 2000;71:188-201. 
Pini Prato GP, Baldi C, Nieri M, Franseschi D, Corttllini P, Clauser C, Rotundo R, Muzzi L. Coronally advanced flap: The post-surgical position of the gingival margin is an important factor for achieving complete root coverage. J Periodontol 2005;76(5):713722.

Pini Prato GP, Rotundo R, Magnani C, Ficarra G. Viral etiology of gingival recession: A case report. J Periodontol 2002;73:110-114.

Raetzke PB. Covering localized areas of root exposure employing the "envelope" technique. J Periodontol 1985;56:397-402.

Rahmani ME, Lades MA. Comparative clinical evaluation of acellular dermal matrix allograft and connective tissue graft for the treatment of gingival recession. J Clin Periodontol 2006;7(2):63-70.

Ricci G, Silvestri M, Tinti C, Rasperini G. A clinical/statistical comparison between the subpedicle connective tissue graft method and the guided tissue regeneration technique in root coverage. Int J Periodontics Restorative Dent 1996;16(6):538-545.

Romagna-Genon C. Comparative clinical study of guided tissue regeneration with a bioabsorbable bilayer collagen membrane and subepithelial connective tissue graft. J Periodontol 2001;72:1258-1264.

Romanos G, Bernimoulin JP, Marggraf E. The double lateral bridging flap for coverage of denuded root surface: longitudinal study and clinical evaluation after 5 to 8 years. $\mathbf{J}$ Periodontol 1993;64:683-688.

Rosetti EP, Marcantonio RA, Rossa C Jr, Chaves ES, Goissis G, Marcantonio E Jr. Treatment of gingival recession: comparative study between subepithelial connective tissue graft and guided tissue regeneration. J Periodontol 2000;71:1441-1447. 
Saletta D, Pini Prato G, Pagliaro U, Baldi C, Mauri M, Nieri M. Coronally advanced flap procedure: is the interdental papilla a prognostic factor of root coverage? J Periodontol $2001 ; 72: 760-766$.

Salkin LM, Freedman AL, Stein MD, Bassiouny MA. A longitudinal study of untreated mucogingival defects. J Periodontol 1987;58(3):164-166.

Santos A, Goumenos G, Pascual A. Management of gingival recession by the use of an acellar dermal graft material: A 12-case series. J Periodontol 2005;76(11):1982-1990.

Serino G, Wennstrom JL, Lindhe J, Eneroth L. The prevalence and distribution of gingival recession in subjects with high standard of oral hygiene. J Clin Periodontol 1994;21:57-63.

Shepherd N, Greenwell H, Hill M, Vidal R, Scheetz JP. Root coverage using acellular dermal matrix and comparing a coronally positioned tunnel with and without platelet-rich plasma: a pilot study in humans. J Periodontol 2009;80(3):397-404.

Silness J, Löe H. Periodontal disease in pregnancy. II. Correlation between oral hygiene and periodontal conditions. Acta Odontol Scand 1964;22(1):121-135.

Silva CO, Sallum AW, de Lima AF, Tatakis DN. Coronally positioned flap for root coverage: poorer outcomes in smokers. J Periodontol 2006;77(1):81-7.

Smith RG. Gingival recession. Reappraisal of an enigmatic condition and a new index for monitoring. J Clin Periodontol 1997;24:201-205.

Smukler H, Goldman HM. Laterally repositioned "stimulated" osteoperiosteal pedicle grafts in the treatment of denuded roots. A preliminary report. J Periodontol 1979;50:379383. 


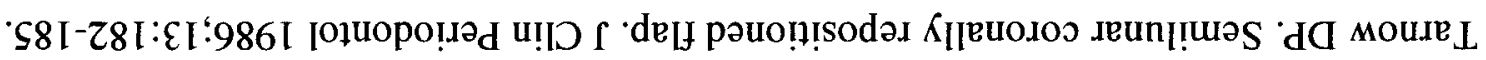

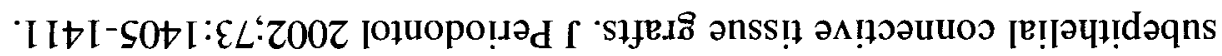

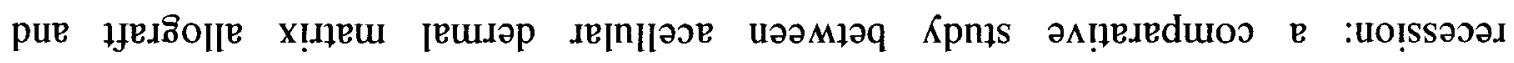

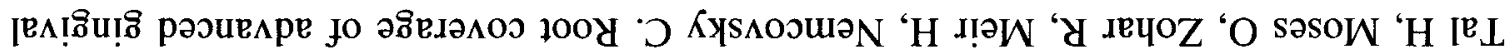

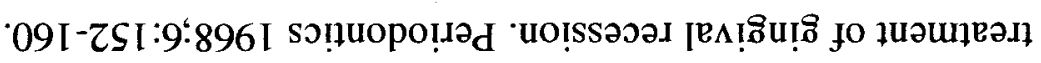

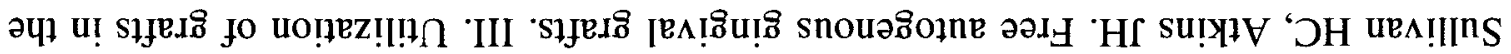

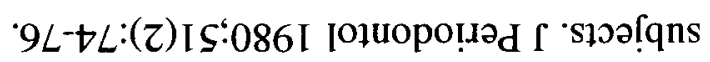

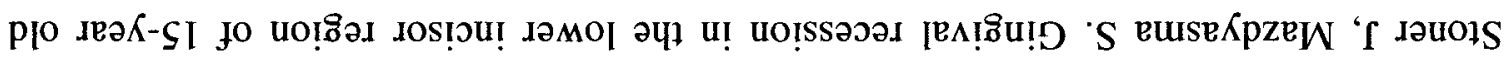

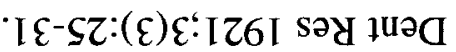

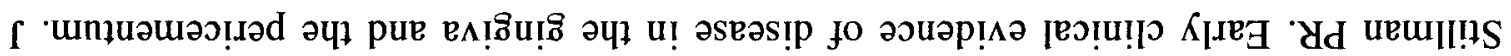

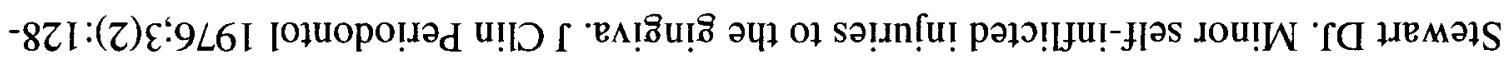

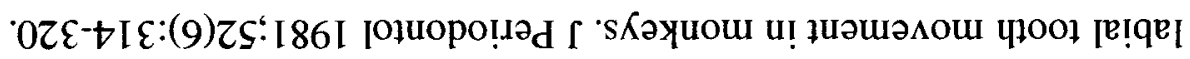

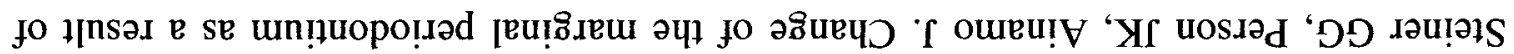

$088 \mathrm{I}^{-} \mathrm{I} \angle 8 \mathrm{I}:$ ( I I $) 9 L$ L $500 Z$

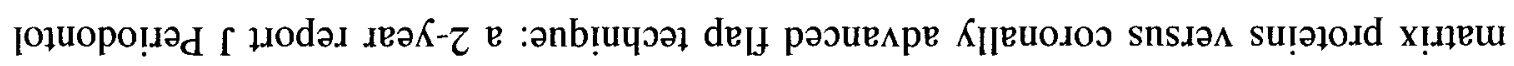

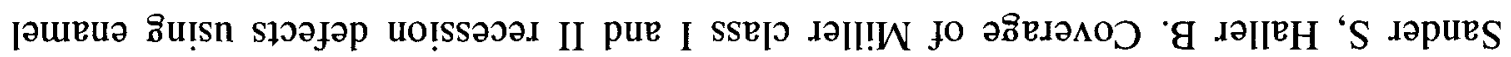

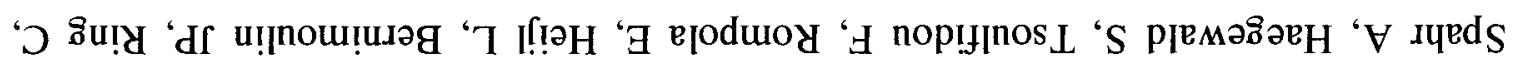

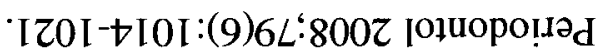

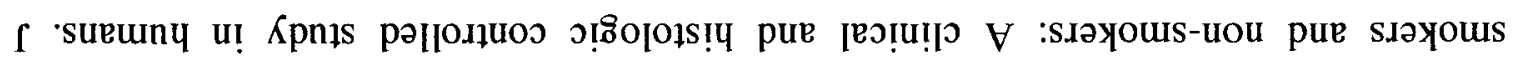

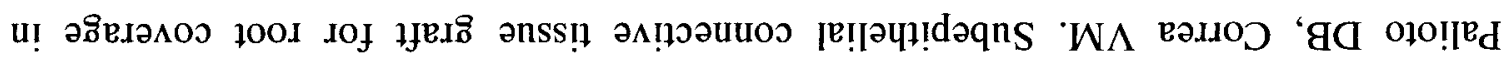

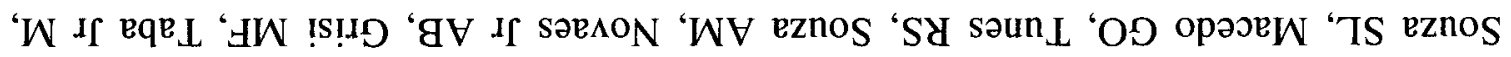


Tatakis DN, Trombelli L. Gingival recession treatment: guided tissue regeneration with bioabsorbable membrane versus a connective tissue graft. J Periodontol 2000;71:299307.

Tinti C, Parma-Benfenati S. The free rotated papilla autograft: a new bilaminar grafting procedure for the coverage of multiple shallow gingival recessions. J Periodontol 1996;67:1016-1024.

Tozum TF, Keceli HG, Guncu N, Hatipoglu H, Sengun D. Treatment of gingival recession: Comparison of two techniques of subepithelial connective tissue graft. J Periodontol 2005;76(10):1842-1848.

Trombelli L, Scabbia A, Tatakis DN, Calura G. Subpedicle connective tissue graft versus guided tissue regeneration with bioabsorbable membrane in the treatment of human gingival recession defects. J Periodontol 1998;69:1271-1277.

Trombelli L, Scabbia A, Wikesjo UM, Calura G. Fibrin glue application in conjunction with tetracycline root conditioning and coronally positioned flap in the treatment of human gingival recession defects. J Clin Periodontol 1996;23:861-867.

Turner $\mathrm{CH}$. A retrospective study of the fit of jacket crowns placed around gold posts and cores, and their associated gingival health. J Oral Rehabil 1982;9(5):427-434.

Vergara JA, Caffesse RG. Localized gingival recessions treated with the original envelope technique: A report of 50 consecutive patients. J Periodontol 2004;75(10):13971403.

Wang HL, Bunyaratavej P, Labadie M, Shyr Y, MacNeil RL. Comparision of 2 clinical techniques for treatment of gingival recession. J Periodontol 2001;72:1301-1311. 
Ward V. A clinical assessment of the use of the free gingival graft for correcting localized recession associated with frena pull. J Periodontol 1974;45:78.

Wennström JL. Lack of association between width of attached gingiva and development of soft tissue recession. A five year longitudinal study. J Clin Periodontol $1987 ; 14(3): 181-184$

Wennström JL, Zucchelli G. Increased gingival dimensions. A significant factor for successful outcome of root coverage procedures? A 2-year prospective clinical study. J Clin Periodontol 1996;23:770-777.

Wilson TG, McGuire MK, Nunn ME. Evaluation of the safety and efficacy of periodontal applications of a living tissue-engineered human fibroblast--derived dermal substitute. II. Comparison to the subepithelial connective tissue graft: A randomized controlled feasibility study. J Periodontol 2005;76(6):881-889.

Woodyard JG, Greenwell H, Hill M, Drisko C, Iasella JM, Scheetz J. The clinical effect of acellular dermal matrix on gingival thickness and root coverage compared to coronally positioned flap alone. J Periodontol 2004;75:44-56.

Yankell SL, Emling RC, Volpe AR. New perspectives regarding calculus and gingival recession. J Clin Dent 1991;3(1):27-32.

Zabalegui I, Sicilia A, Cambra J, Gil J, Sanz M. Treatment of multiple adjacent gingival recessions with the tunnel subepithelial connective tissue graft: a clinical report. Int $\mathbf{J}$ Periodontics Restorative Dent 1999;19(2):199-206.

Zucchelli G, Amore C, Sforza NM, Mantobugnoli L. DeSanctis M. Bilaminar techniques for the treatment of recession-type defects. A comparative clinical study. J Clin Periodontol 2003;30:862-870. 
Zucchelli G, Clauser C, DeSanctis M, Calandriello M. Mucogingival versus guided tissue regeneration procedures in the treatment of deep recession type defects. J Periodontol 1998;69:138-145.

Zucchelli G, DeSanctis M. Treatment of multiple recession-type defects in patients with esthetic demands. J Periodontol 2000;71:1506-1514.

Zucchelli G, DeSanctis M. Long-term outcome following treatment of multiple Miller Class I and II recession defects in esthetic areas of the mouth. J Periodontol 2005;76(12):2286-2292.

Zucchelli G, Mele M, Mazzotti C, Marzadori M, Montebugnoli L, De Sanctis M. Coronally advanced flap with and without vertical releasing incisions for the treatment of multiple gingival recessions: a comparative controlled randomized clinical trial. J Periodontol 2009;80(7):1083-94.

Zucchelli G, Testori T, De Sanctis M. Clinical and anatomical factors limiting treatment outcomes of gingival recession: a new method to predetermine the line of root coverage. J Periodontol 2006;77(4):714-21. 


\title{
APPENDIX A
}

\section{Presurgical measurements}

Measurements for probing depths, clinical attachment levels, and gingival margin levels will be taken at 6 sites on both buccal and lingual surfaces relative to the CEJ.

\author{
1. Mesial buccal line angle. \\ 2. Mid-buccal. \\ 3. Distal buccal line angle. \\ 4. Mesial lingual line angle. \\ 5. Mid-lingual. \\ 6. Distal lingual line angle.
}

Measurements for the width of keratinized gingiva will be from the mid facial tooth surface.

Measurements for the gingival thickness will be taken mid-facial on test sites and control sites at the base of the sulcus and at the mucogingival junction level. 


\section{APPENDIX B}

\section{Surgical Measurements}

\section{A. Defect Height:}

All measurements made in relation to the CEJ.

1. CEJ to alveolar crest: From the CEJ to the alveolar crest measured at 3 points.

a. Mesial buccal line angle to the interproximal crest. (A)

b. Midbuccal CEJ to defect depth. (D)

c. Distal buccal line angle to the interproximal crest (C)

\section{B. Defect Width:}

1. Width of dehiscence defect, measured at the interproximal osseous crest. (B)

2. Width of dehiscence defect, measured $1.0 \mathrm{~mm}$ coronal to the defect depth. (E)

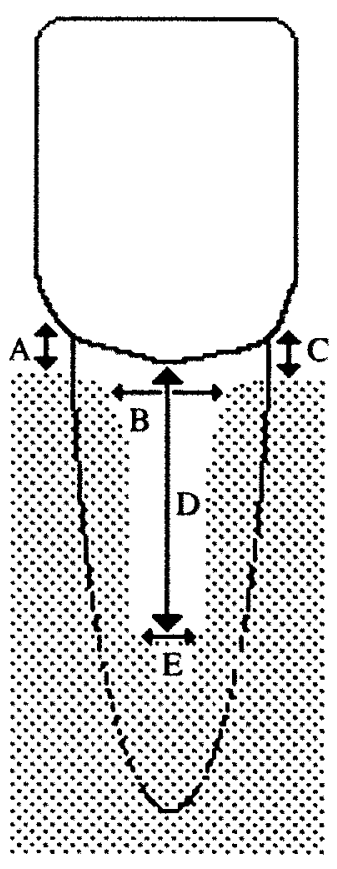




\section{APPENDIX C}

\section{$\underline{\text { Recession Classification }}$}

Miller's Classification (1985) of recession defects will be measured for the test and control sites. Scores will be recorded as follows:

Class I $=$ Marginal tissue recession that does not extend to the mucogingival junction. There is no periodontal loss (bone or soft tissue) in the interdental area, and $100 \%$ root coverage can be anticipated.

Class II $=$ Marginal tissue recession which extends to or beyond the mucogingival junction. There is no periodontal loss (bone or soft tissue) in the interdental area, and $100 \%$ root coverage can be anticipated.

Class III $=$ Marginal tissue recession which extends to or beyond the mucogingival junction. Bone or soft tissue loss in the interdental area is present or there is malpositioning of the teeth that prevents the attempting of $100 \%$ root coverage. Partial root coverage can be anticipated.

Class IV = Marginal tissue recession which extends to or beyond the mucogingival junction. The bone or soft tissue loss in the interdental area and/or malpositioning of teeth is so severe that root coverage cannot be anticipated. 


\section{APPENDIX D}

\section{Plaque Index}

The plaque index of Silness and Loe (1964) will be measured for the test and control sites. The scores will be recorded as follows:

\section{$0=$ No Plaque}

$1=$ A film of plaque adhering to the free gingival margin and adjacent area of the tooth. The plaque may be seen in situ only after the application of disclosing solution or by using the probe on the tooth surface.

$2=$ Moderate accumulation of soft deposits within the gingival pocket, or on the tooth and gingival margin which can be seen with the naked eye.

$3=$ Abundance of soft matter within the gingival pocket and/or on the tooth and gingival margin.

Each gingival unit (mesiobuccal, buccal, distobuccal, distolingual, lingual, mesiolingual) of the tooth will be given a score $0-3$. The scores for each unit will be added together and divided by 6 to give the plaque index for that tooth. The score of the test tooth and the two adjacent teeth will be added and divided by 3 to give the plaque index for the test of control sites. 


\section{APPENDIX E}

\section{Gingival Index}

The Gingival Index (Lobene et al. 1986) will be measured. Scores will be as follows:

0 - Normal gingiva

1 - Mild inflammation - slight change in color, slight edema

2 - Moderate inflammation - redness, edema, and glazing.

3 - Severe inflammation - marked redness and edema. Ulceration.

Each gingival unit (buccal, lingual, mesiobuccal, distobuccal, mesiolingual, and distolingual) of the individual tooth will be given a score from $0-3$, called the gingival index for the area. The scores from the 6 areas of the tooth are added and divided by 6 to give the gingival index for the tooth. 


\section{APPENDIX F}

\section{Bleeding on Probing Index}

Bleeding on probing to the bottom of the pocket will be scored as follows:

$$
\begin{aligned}
& 0=\text { No bleeding } \\
& 1=\text { Bleeding } .
\end{aligned}
$$




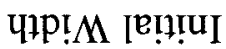

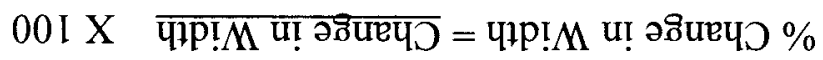

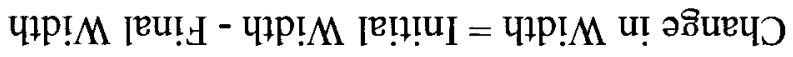

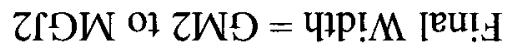 \\ IIDW of IWD = ЧIp!M [R!!!UI

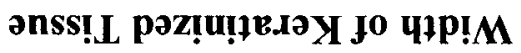

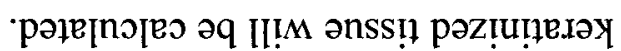

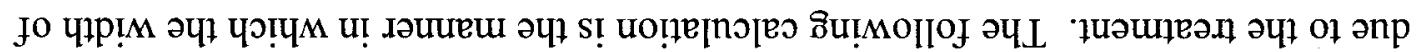

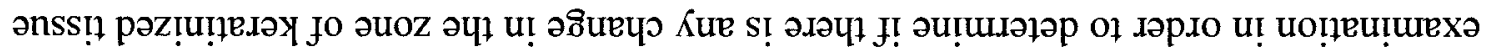

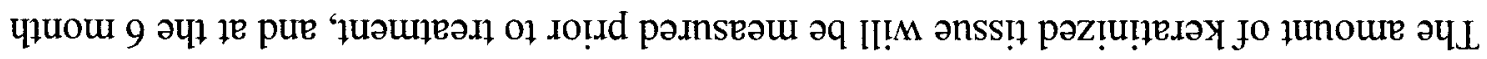

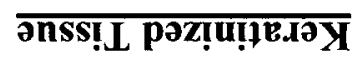




\section{APPENDIX H}

\section{Tooth Mobility}

Miller proposed the following tooth mobility index:

$0=$ Movability of the crown within normal physiologic limits.

1 = Movability of the crown up to $0.5 \mathrm{~mm}$ in one direction, but does not exceed $1.0 \mathrm{~mm}$ in both directions.

$2=$ Movability of the crown from 0.5 to $1.0 \mathrm{~mm}$ in one direction, but does not exceed $2.0 \mathrm{~mm}$ in both directions.

$3=$ Movability of the crown exceeding $1.0 \mathrm{~mm}$ in one direction and/or vertical depressibility. Greater that $2.0 \mathrm{~mm}$ in both directions and/or vertical depressibility.

The index that will be used in the study is a modification of Miller's index (Laster et al. 1975), where half scores are used. Thus scores of $0,0.5,1.0,1.5,2.0,2.5$, and 3.0 will be utilized. 


\title{
APPENDIX I
}

\section{Creeping Attachment}

Creeping attachment (Goldman, 1964) is the result of the coronal migration of the grafted gingiva, taking place after the completed healing of the surgical site.

Root coverage will be determined by the amount of initial recession minus the final recession. The final recession will take into account the amount of creeping attachment that has occurred. The creeping attachment will be measured starting at 8 weeks post-operatively, and measured monthly until the 6-month examination. Creeping attachment has been shown to occur between 1 month and 1 or 2 years after surgical procedures.

The following calculation is the manner in which the amount of root coverage has been obtained:

\author{
Amount of Root Coverage \\ Initial Recession $=\mathrm{CEJ}-\mathrm{GM}_{1}$ \\ Final Recession $=\mathrm{CEJ}-\mathrm{GM}_{2}$ \\ Root Coverage $=$ Initial Recession - Final Recession \\ $\%$ Root Coverage $=\underline{\text { Root Coverage }} \times 1$ \\ Initial Recession
}

Also reported will be:

Frequency of $100 \%$ root coverage

Frequency of $90 \%$ root coverage 


\title{
CURRICULUM VITAE
}

\author{
Courtney Tyler Shearer, D.M.D.
}

EDUCATION

\author{
University of Louisville, Graduate Periodontics Residency,
} Louisville, KY, 40292. July 2007-June 2010. Specialty Certificate Periodontics and MS Oral Biology.

Rotation Anesthesiology, University of Louisville Hospital. May 2008.

Rotation Internal Medicine, University of Louisville Hospital. June 2008.

University of Louisville Dental School (ULSD), Louisville, KY, 40292. July 2003-May 2007. Doctor of Dental Medicine.

University of Louisville, Louisville, KY. Spring 2001-Spring

2003. Post-baccalaureate status. Dental school prerequisite science courses.

Northern Virginia Community College, Alexandria, VA. Fall 2000. Microcomputer Operating Systems, Architecture, and Hardware Class.

Wells College, Florence, Italy. Spring 1998.

Scholastic study abroad program.

Washington and Lee University, Lexington, VA September 1995-June 1999. B. A. Geology, Environmental Studies concentration.

\section{RESEARCH EXPERIENCE}

University of Louisville, Graduate Periodontics Residency, Louisville, KY, 40292. A Comparison of Two Suturing Techniques for the Coronally Positioned Tunnel Procedure with an Acellular Dermal Matrix Allograft (Master's Thesis; underway) University of Louisville, Graduate Periodontics Residency, Louisville, KY, 40292. The Effect of a Laser Grooved Implant Collar Compared to a Standard Implant Collar on Peri-Implant Hard and Soft Tissue Healing. (Co-investigator) University of Louisville School of Dentistry, May 2005-August 2005. Shearer C., Greenwell H., Hill M., Kinane D. Oral Bisphosphonates Do Not Adversely Impact Periodontal Flap Surgery. 
ACADEMIC AWARDS

Southern Academy of Periodontology $3^{\text {rd }}$ Place Pennel Award. June 2010.

American Academy of Periodontology A ward, ULSD, 2007.

Honors, Head and Neck Anatomy, ULSD, 2004.

Dean's List, ULSD, July 2003-December 2004.

Phi Kappa Phi Honor Society Nominee, University of Louisville (undergraduate), 2003.

TEACHING EXPERIENCE

Clinical Teaching Assistant, Clinical Periodontology Course, University of Louisville, 2008-2009.

Clinical Supervisor, Clinical Coverage of Periodontics for

DMD Students, University of Louisville, 2008-2009.

\section{SERVICE / ACTIVITIES}

ULSD Class of 2007 Treasurer, 2003-2005.

ULSD Tutor for Gross Anatomy, Fall 2005.

ULSD Class Representative, Introduction to Periodontics, 20032004.

Dental Mission Trip, Dominican Republic. Summer 2004.

ULSD Christian Medical and Dental Association, 2003-2007.

Leukemia Society of America's Team in Training, Washington, DC. 2000 . Raised $\$ 3200$ for team sponsored leukemia patients.

Completed Nashville Country Music Marathon.

Washington and Lee University Varsity Swim Team, 19951997, 1998-1999.

Big Brother/Big Sister Lexington, VA Committee, 1996-1998.

Outward Bound Expedition, North Carolina. Summer 1993.

\section{PROFESSIONAL ASSOCIATIONS}

American Association of Periodontology (AAP), 2007-present. Kentucky Association of Women Dentists (KAWD), 2010present.

Southern Indiana Dental Association (SIDA), 2010-present. American Association of Women Dentists (AAWD), 2005-2006. American Dental Association (ADA), 2003-2007. Louisville American Student Dental Association (LASDA), 2003-2007.

American Student Dental Association (ASDA), 2003-2007. 
EMPLOYMENT Humana Inc., Information Management Analyst. Louisville, KY 2001-2003.

Project Performance Corporation, Research Associate. McLean, VA. 1999-2000.

Internship with The United States Environmental Protection Agency, Office of Policy's (OP) Office of Sustainable Ecosystems and Communities (OSEC), Washington, DC. 1998. 